\title{
\#USES
}

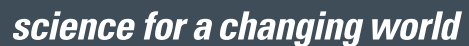

Prepared in cooperation with the Washington State Department of Ecology and the Bureau of Reclamation

\section{Simulation of Groundwater Storage Changes in the Cuincy Basin, Washington}
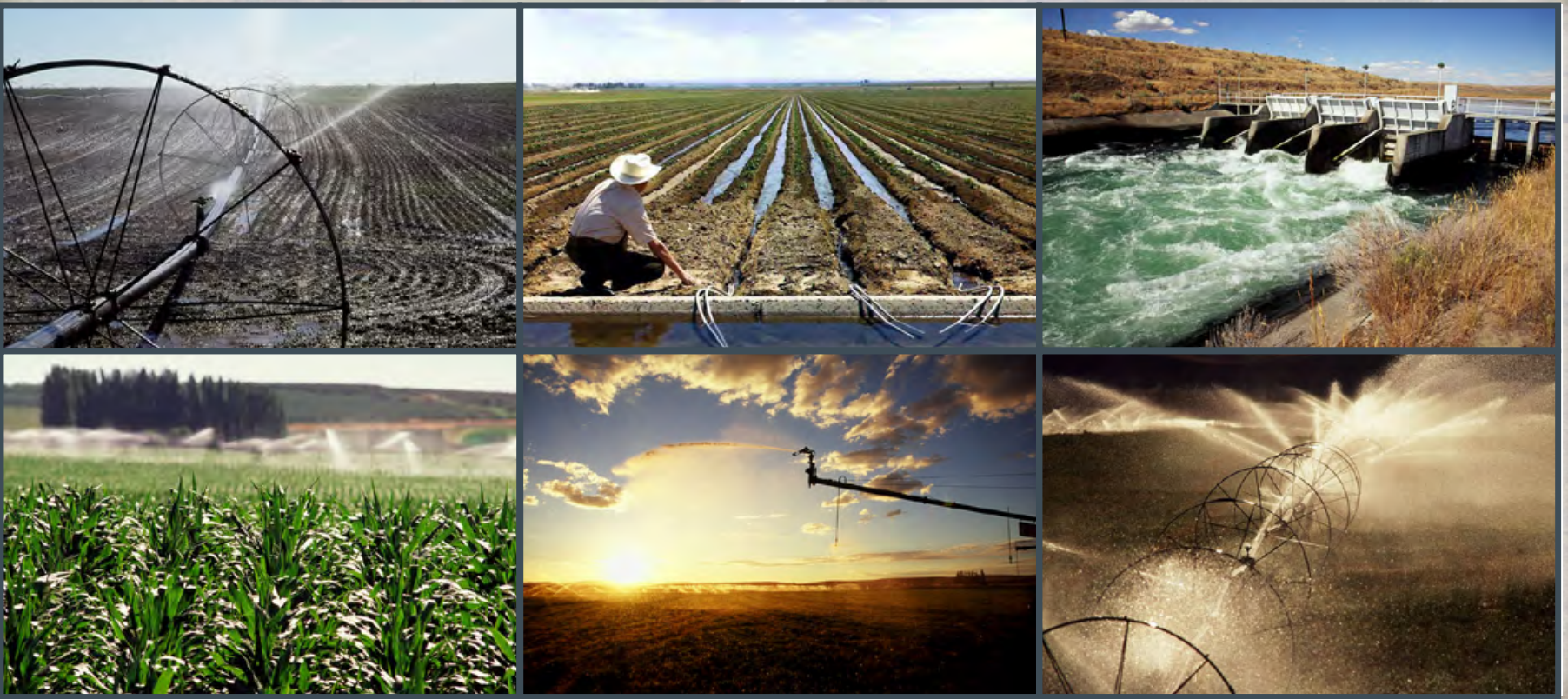

Scientific Investigations Report 2018 - 5162

U.S. Department of the Interior U.S. Geological Súvey
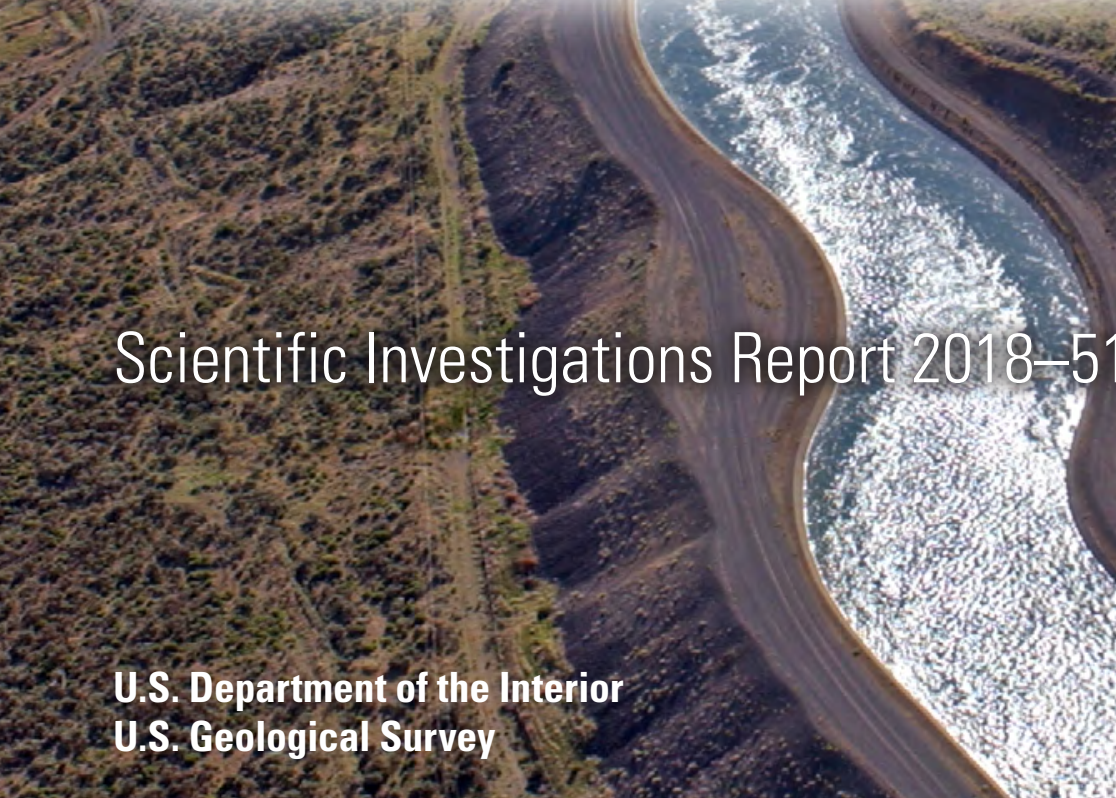
Cover: Photograph showing West Canal flowing west away from Pinto Dam towards Soap Lake, Washington. Photograph by Dave Walsh, Bureau of Reclamation, May 3, 2004.

\section{Inset photographs, clockwise from top left:}

Harvest and irrigation activities in the Quincy area, Washington. Photograph by Andy Pernick, Bureau of Reclamation, August 22, 1999.

Concrete-lined head ditch carrying water for gravity-flow irrigation on this farm in Winchester, Washington. Photograph by J.D. Roderick, Bureau of Reclamation, May 30, 1973.

East Low and West canal bifurcation works, Washington. Photograph by Dave Walsh, Bureau of Reclamation, August 22, 1999.

Low-head pivot, wheels irrigation activity in the Ephrata area, Washington. Photograph by Dave Walsh, Bureau of Reclamation, August 22, 1999.

Low-head pivot, wheels irrigation activity in the Ephrata area, Washington. Photograph by Dave Walsh, Bureau of Reclamation, August 22, 1999.

Corn, wheat, and spinach crops in the Royal Slope area, Washington. Photograph by Dave Walsh, Bureau of Reclamation, August 22, 1999. 


\section{Simulation of Groundwater Storage Changes in the Quincy Basin, Washington}

By Lonna M. Frans, Sue C. Kahle, Alison E. Tecca, and Theresa D. Olsen

Prepared in cooperation with the Washington State Department of Ecology and the Bureau of Reclamation

Scientific Investigations Report 2018-5162 


\section{U.S. Department of the Interior \\ RYAN K. ZINKE, Secretary}

\section{U.S. Geological Survey James F. Reilly II, Director}

\section{U.S. Geological Survey, Reston, Virginia: 2018}

For more information on the USGS - the Federal source for science about the Earth, its natural and living resources, natural hazards, and the environment-visit https://www.usgs.gov or call 1-888-ASK-USGS.

For an overview of USGS information products, including maps, imagery, and publications, visit https://store.usgs.gov.

Any use of trade, firm, or product names is for descriptive purposes only and does not imply endorsement by the U.S. Government.

Although this information product, for the most part, is in the public domain, it also may contain copyrighted materials as noted in the text. Permission to reproduce copyrighted items must be secured from the copyright owner.

Suggested citation:

Frans, L.M., Kahle, S.C., Tecca, A.E., and Olsen, T.D., 2018, Simulation of groundwater storage changes in the Quincy Basin, Washington: U.S. Geological Survey Scientific Investigations Report 2018-5162, 63 p., https://doi.org/10.3133/ sir20185162.

ISSN 2328-0328 (online) 


\section{Contents}

Abstract

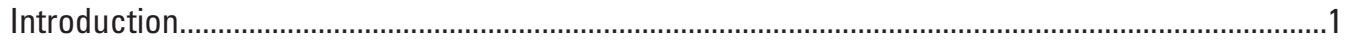

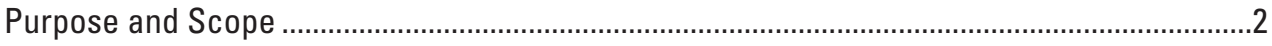

Description of Study Area ...............................................................................................

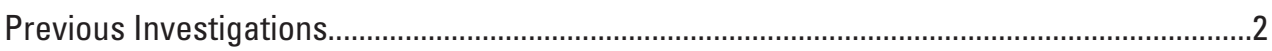

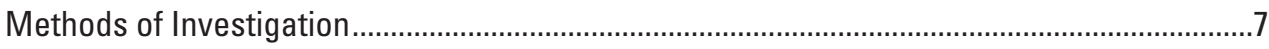

Well Data

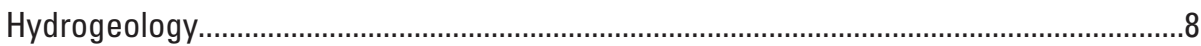

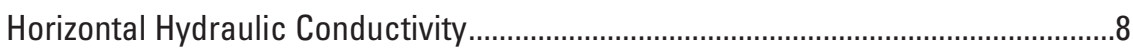

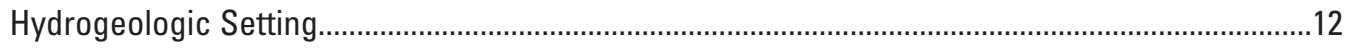

Columbia River Basalt Group (CRBG) Hydrogeologic Unit .............................................12

Unconsolidated Sedimentary Hydrogeologic Units ..........................................................12

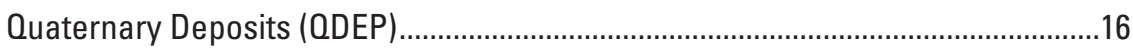

Ringold Formation (RING) ...........................................................................16

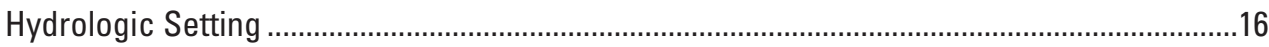

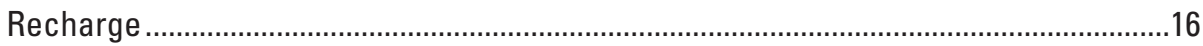

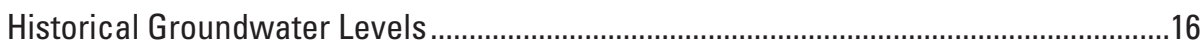

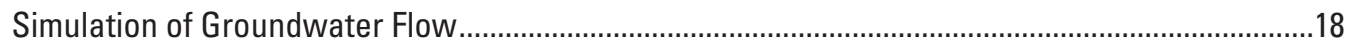

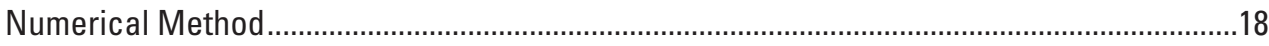

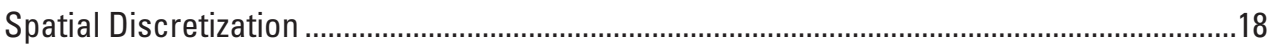

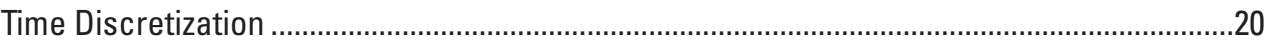

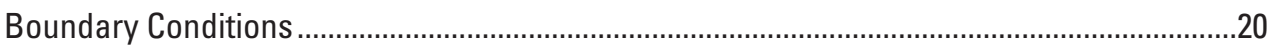

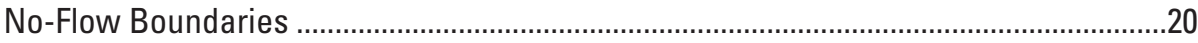

Specified Flux Boundaries ....................................................................................20

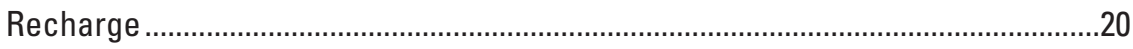

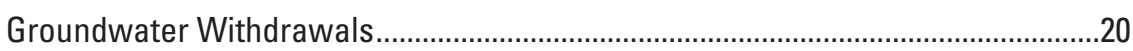

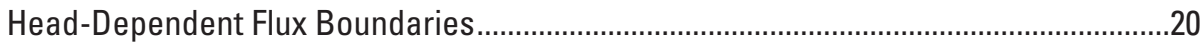

General Head Boundaries .......................................................................................

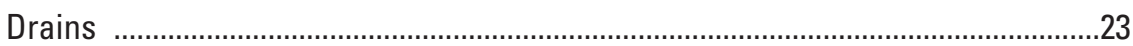

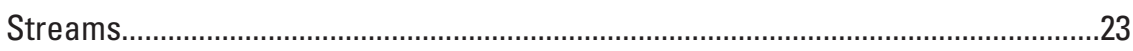

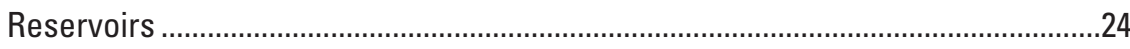

Horizontal Flow Barriers ............................................................................................

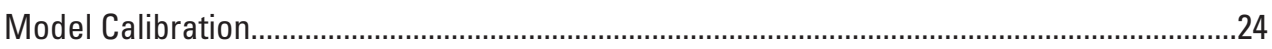

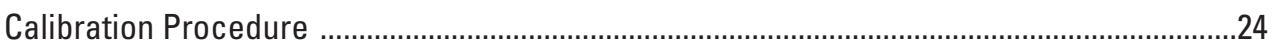

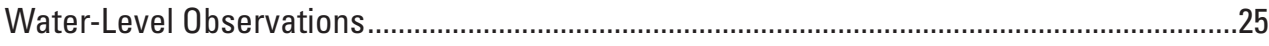

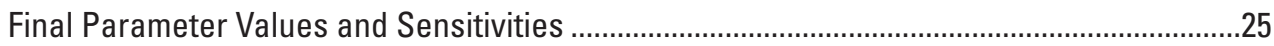

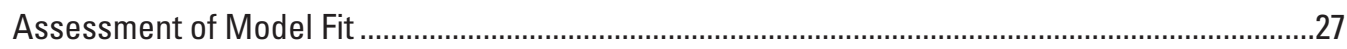

Comparison of Measured and Simulated Hydraulic Heads ..................................................27

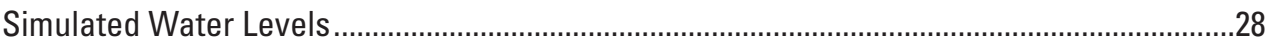

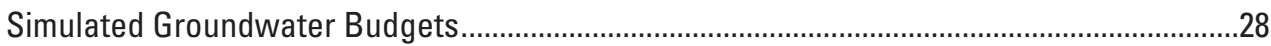

Simulated Storage Changes in the Quincy Subarea.........................................................34

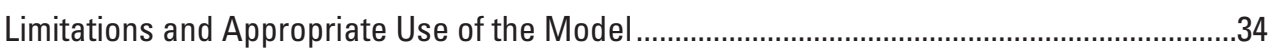

Examples of Errors in Model Input Data ......................................................................... 


\section{Contents-Continued}

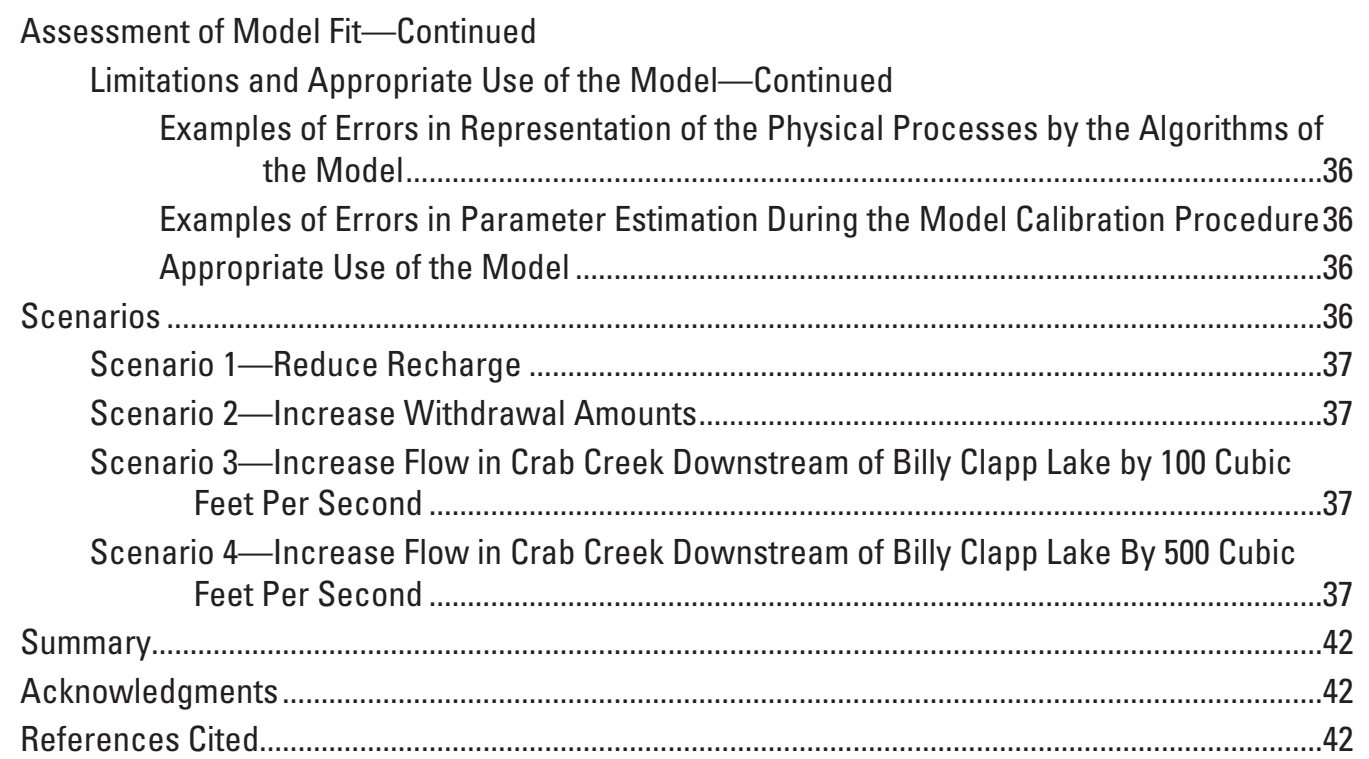

\section{Figures}

1. Map showing location of the active model domain and the Quincy Groundwater Management Subarea, Quincy Basin, Washington.

2. Map showing simplified National Land Cover of the Quincy Basin study area, Washington, 2006.

3. Map showing locations of rivers, water-delivery infrastructure, and buried drains in the Quincy Basin study area, Washington.

4. Map showing locations of selected hydrogeologic studies of the Quincy Basin and selected adjacent areas, Washington

5. Map showing simplified surficial geology of the Quincy Basin study area, Washington 9

6. Map showing surficial hydrogeology and locations of project wells of the Quincy

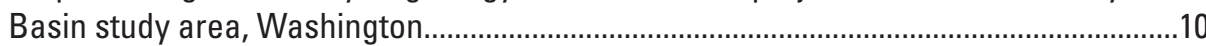

7. Hydrogeologic cross sections of the Quincy Basin study area, Washington

8. Map showing top altitude of basalt surface in the Quincy Basin study area, Washington

9. Map showing extent and thickness of combined overburden units in the Quincy Basin study area, Washington.

10. Map showing contours of water levels measured in wells, 1939-45 $(A)$; and hydrograph of well at location $\mathrm{A}(B)$, Quincy Basin, Washington

11. Map showing finite-difference grid for the groundwater model with stream, reservoir, and drain cells; general-head boundary cells; and horizontal-flow barriers, Quincy Basin, Washington.

12. Map showing distribution of recharge specified in the Quincy Basin model domain, Quincy Basin, Washington, 2007

13. Map showing locations of simulated withdrawal wells and SOil WATer balance (SOWAT) model-estimated groundwater withdrawals, Quincy Basin, 


\section{Figures-Continued}

14. Graph showing total annual groundwater withdrawals simulated from the Quincy Basin, Washington, 1920-2014.

15. Graph showing measured compared to simulated water levels in the Quincy Basin, Washington.

16. Graph showing simulated magnitudes of hydraulic-head residuals in the Quincy Basin, Washington.

17. Map showing contours of simulated water-level altitudes, Quincy Basin, Washington, 2013.

18. Map showing simulated changes in water-level altitude, Quincy Basin, Washington, 1920-2013...

19. Graph showing simulated net flows into the groundwater model domain, Quincy Basin, Washington, 1920-2013 . .32

20. Map showing water budget areas, Quincy Basin, Washington, 1920-2013. .33

21. Graph showing cumulative simulated changes in groundwater storage in the model domain and areas in the Quincy Groundwater Management Subarea, Quincy Basin, Washington, 1920-2013.

22. Map showing simulated water-level changes after reducing 2013 irrigation amounts by 10 percent, Quincy Basin, Washington

23. Map showing simulated water-level changes after increasing groundwater withdrawal amounts by 2,000 acre-feet per year, Quincy Basin, Washington.

24. Map showing simulated water-level changes after increasing flow in Crab Creek downstream of Billy Clapp Lake by 100 cubic feet per second, Quincy Basin, Washington.

25. Map showing simulated water-level changes after increasing flow in Crab Creek downstream of Billy Clapp Lake by 500 cubic feet per second, Quincy Basin, Washington.

\section{Tables}

1. Geologic and hydrogeologic units of the Quincy Basin study area, Adams, Grant, and Lincoln Counties, Washington

2. Parameter sensitivities and final values for all parameters used in calibration of groundwater model for Quincy Basin, Washington

3. Groundwater budget of the Quincy Groundwater Management Subarea, Quincy Basin, Washington, pre-1920 and 2013

4. Groundwater budget of the High Hills Irrigation development area, Moses Lake Irrigation Rehabilitation District, and the City of Quincy, Washington, 2013.

5. Selected physical and hydrologic data for the project wells in the Quincy Basin study area, Washington 


\section{Conversion Factors}

Inch/Pound to International System of Units

\begin{tabular}{|c|c|c|}
\hline Multiply & By & To obtain \\
\hline \multicolumn{3}{|c|}{ Length } \\
\hline inch (in.) & 25.4 & millimeter $(\mathrm{mm})$ \\
\hline foot $(\mathrm{ft})$ & 0.3048 & meter $(\mathrm{m})$ \\
\hline mile (mi) & 1.609 & kilometer $(\mathrm{km})$ \\
\hline \multicolumn{3}{|c|}{ Area } \\
\hline acre & 4,047 & square meter $(\mathrm{m})$ \\
\hline acre & 0.4047 & hectare (ha) \\
\hline square mile $\left(\mathrm{mi}^{2}\right)$ & 2.590 & square kilometer $\left(\mathrm{km}^{2}\right)$ \\
\hline \multicolumn{3}{|c|}{ Volume } \\
\hline acre-foot (acre-ft) & 1,233 & cubic meter $\left(\mathrm{m}^{3}\right)$ \\
\hline acre-foot (acre-ft) & 0.001233 & cubic hectometer $\left(\mathrm{hm}^{3}\right)$ \\
\hline million acre-foot (million acre-ft) & $1,233.48$ & million cubic meter (million m3) \\
\hline \multicolumn{3}{|c|}{ Flow rate } \\
\hline acre-foot per year (acre-ft/yr) & 1,233 & cubic meter per year $\left(\mathrm{m}^{3} / \mathrm{yr}\right)$ \\
\hline acre-foot per year (acre-ft/yr) & 0.001233 & cubic hectometer per year $\left(\mathrm{hm}^{3} / \mathrm{yr}\right)$ \\
\hline cubic foot per day $\left(\mathrm{ft}^{3} / \mathrm{d}\right)$ & 0.02832 & cubic meter per day $\left(\mathrm{m}^{3} / \mathrm{d}\right)$ \\
\hline inch per year (in/yr) & 25.4 & millimeter per year (mm/yr) \\
\hline \multicolumn{3}{|c|}{ Hydraulic conductivity } \\
\hline foot per day (ft/d) & 0.3048 & meter per day $(\mathrm{m} / \mathrm{d})$ \\
\hline \multicolumn{3}{|c|}{ Transmissivity and Conductance } \\
\hline square foot per day $\left(\mathrm{ft}^{2} / \mathrm{d}\right)$ & 0.09290 & square meter per day $\left(\mathrm{m}^{2} / \mathrm{d}\right)$ \\
\hline
\end{tabular}

International System of Units to Inch/Pound

\begin{tabular}{lccc}
\hline Multiply & By & To obtain \\
\hline & Length & & \\
\hline kilometer $(\mathrm{km})$ & 0.6214 & mile $(\mathrm{mi})$ & \\
\hline
\end{tabular}

Temperature in degrees Fahrenheit $\left({ }^{\circ} \mathrm{F}\right)$ may be converted to degrees Celsius $\left({ }^{\circ} \mathrm{C}\right)$ as follows:

$$
{ }^{\circ} \mathrm{C}=\left({ }^{\circ} \mathrm{F}-32\right) / 1.8 \text {. }
$$

\section{Datums}

Vertical coordinate information is referenced to the North American Vertical Datum of 1988 (NAVD 88).

Horizontal coordinate information is referenced to the North American Datum of 1983 (NAD 83). Altitude, as used in this report, refers to distance above the vertical datum. 


\section{Abbreviations}

$\begin{array}{ll}\text { CBP } & \text { Columbia Basin Project } \\ \text { CRBG } & \text { Columbia River Basalt Group } \\ \text { DEM } & \text { Digital Elevation Model } \\ \text { Ecology } & \text { Washington State Department of Ecology } \\ \text { GHB } & \text { General Head Boundary package of MODFLOW } \\ \text { GIS } & \text { geographic information system } \\ \text { GWMA } & \text { Columbia Basin Ground Water Management Area } \\ \text { HFB } & \text { Horizontal Flow Barrier } \\ \text { MODFLOW } & \text { USGS modular three-dimensional finite-difference groundwater-flow model } \\ \text { NWT } & \text { Newton Solver package of MODFLW } \\ \text { NWIS } & \text { National Water Information System } \\ \text { PEST } & \text { parameter estimation program } \\ \text { ODEP } & \text { Quaternary deposits } \\ \text { Ouincy Subarea } & \text { Quincy Groundwater Management Subarea } \\ \text { RASA } & \text { U.S. Geological Survey Regional Aquifer-System Analysis } \\ \text { Reclamation } & \text { Bureau of Reclamation } \\ \text { RING } & \text { Ringold Formation } \\ \text { RMSE } & \text { root-mean-square error } \\ \text { SFR } & \text { Stream Flow Routing package of MODFLOW } \\ \text { SOWAT model } & \text { SOil WATer balance model } \\ \text { USGS } & \text { U.S. Geological Survey } \\ & \end{array}$




\section{Well-Numbering System}

In Washington, wells are assigned numbers that identify their location in a township, range, section, and 40-acre tract. For example, well number 19N/23E-34R01 indicates that the well is in township 19 north of the Willamette Base Line, and range 23 east of the Willamette Meridian. The numbers immediately following the hyphen indicate the section (34) in the township, and the letter following the section $(\mathrm{R})$ gives the 40 -acre tract of the section. The two-digit sequence number (01) following the letter indicates that the well was the first one inventoried in that 40acre tract.

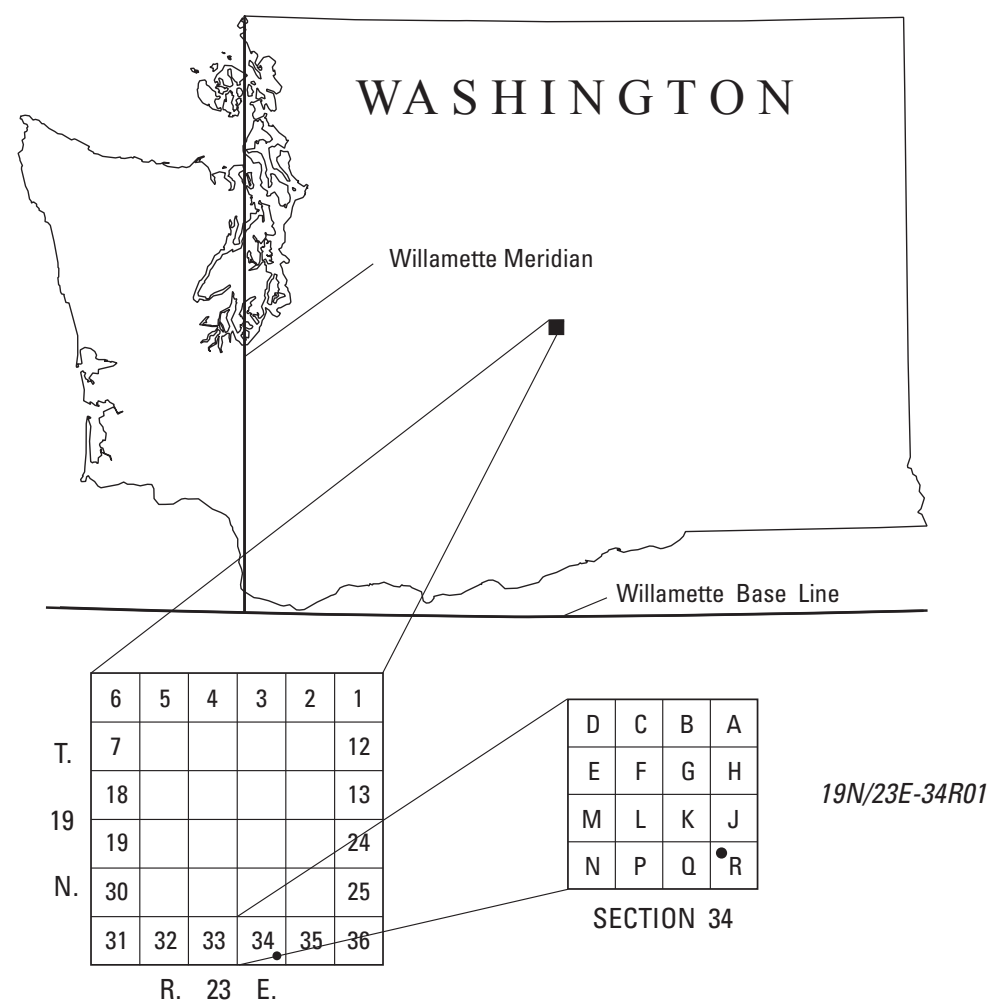

Well numbering system in Washington. 


\title{
Simulation of Groundwater Storage Changes in the Quincy Basin, Washington
}

\author{
By Lonna M. Frans, Sue C. Kahle, Alison E. Tecca, and Theresa D. Olsen
}

\section{Abstract}

The Miocene Columbia River Basalt Group and younger sedimentary deposits of lacustrine, fluvial, eolian, and cataclysmic-flood origins compose the aquifer system of the Quincy Basin in eastern Washington. Irrigation return flow and canal leakage from the Columbia Basin Project have caused groundwater levels to rise substantially in some areas. Water resource managers are considering extraction of additional stored groundwater to supply increasing demand. To help address these concerns, the transient groundwater model of the Quincy Basin documented in this report was developed to quantify the changes in groundwater flow and storage.

The model based on the U.S. Geological Survey modular three-dimensional finite-difference numerical code MODFLOW uses a 1-kilometer finite-difference grid and is constrained by logs from 698 wells in the study area. Five model layers represent two sedimentary hydrogeologic units and underlying basalt formations. Head-dependent flux boundaries represent the Columbia River and other streams, lakes and reservoirs, underflow to and (or) from adjacent areas, and discharge to agricultural drains and springs. Specified flux boundaries represent recharge from precipitation and anthropogenic sources, including irrigation return flow and leakage from water-distribution canals and discharge through groundwater withdrawal wells. Transient conditions were simulated from 1920 to 2013 using annual stress periods. The model was calibrated with the parameter-estimation code PEST to a total of 4,064 water levels measured in 710 wells. Increased recharge since predevelopment resulted in an 11.5 million acre-feet increase in storage in the Quincy Groundwater Management Subarea of the Quincy Basin.

Four groundwater-management scenarios were formulated with input from project stakeholders and were simulated using the calibrated model to provide representative examples of how the model could be used to evaluate the effect on groundwater levels as a result of potential changes in recharge, groundwater withdrawals, or increased flow in Crab Creek. Decreased recharge and increased groundwater withdrawals both resulted in declines in groundwater levels over 2013 conditions, whereas increasing the flow in Crab Creek resulted in increased groundwater levels over 2013 conditions.

\section{Introduction}

Since 1952, water diverted from the Columbia River has been used to irrigate parts of the Bureau of Reclamation (Reclamation) Columbia Basin Irrigation Project (CBP) in eastern Washington. As a result of the large volumes of surface-water irrigation, groundwater levels in the Quincy Groundwater Management Subarea (Quincy Subarea) sediments and upper basalt generally have risen and caused various problems, such as septic system failures and loss of agricultural lands because of ponding. As demands for water use increase, State and local water resource managers are increasingly looking to the additional groundwater in storage as a potential source of water for development. The development of these groundwater resources not only could provide additional water for claim, but also could potentially mitigate some of the adverse consequences of the increased water levels.

Under Washington State law, subject to existing rights, all natural groundwater and all "artificially stored" groundwater that has been abandoned or forfeited are available for appropriation (Washington State Legislature, 2003; Washington Administrative Code [WAC] 508-14-030). The units in the Quincy Subarea situated between ground surface and the top of the uppermost basalt flow, known as the Quincy unconsolidated zone, have large quantities of groundwater in "artificial" storage. That storage extends into the uppermost basalt flows. Thus, artificially stored groundwater in the Quincy Subarea is believed to be present in the shallow management unit, which is defined in a rule to mean that the groundwater is hydraulically continuous between land surface and a depth of $200 \mathrm{ft}$ into the Quincy basalt zone and includes all of the Quincy unconsolidated zone. (Washington State Legislature, 1988; WAC 173-124). 


\section{Purpose and Scope}

The USGS, in cooperation with Reclamation and the Washington State Department of Ecology (Ecology) conducted this study to quantify natural and artificially stored groundwater in the Quincy Subarea. This report (1) describes the hydrogeologic setting and hydrogeologic units of the study area, (2) documents the groundwater-flow model that was developed to quantify the changes of groundwater storage within the Quincy Subarea, (3) evaluates the applicability and accuracy of the model as a predictive tool for assessing changes in groundwater storage, and (4) discusses limitations of the model.

The four primary objectives of this study are to:

1. Define the hydrogeology of the study area,

2. Determine groundwater flow directions and flows through the aquifer system,

3. Quantify the effect of anthropogenic recharge and groundwater withdrawals on storage in the groundwater system, and

4. Simulate the effects of four groundwater-management scenarios.

\section{Description of Study Area}

The Quincy Subarea, described in WAC 173-124-040 (Washington State Legislature, 1988), encompasses 1,100 $\mathrm{mi}^{2}$ in Grant County and a small part of Adams County, Washington (fig. 1). The Quincy Subarea is located within the structural and topographic Quincy Basin, which is bounded on the north by the Beezley Hills, on the south by the Frenchman Hills, on the west by Evergreen and Babcock Ridges, and on the east by the high land east of Moses Lake (Schwennesen and Meinzer, 1918). Altitudes in the study area range from 570 $\mathrm{ft}$ to about 2,500 ft west of Ephrata, with an average altitude of about 1,200 ft. The climate is arid to semi-arid, with mean annual precipitation ranging from 7 to $10 \mathrm{in}$. and occurring primarily during the winter. Average daily temperatures range from the upper $20 \mathrm{~s}^{\circ} \mathrm{F}$ in December and January to more than $90^{\circ} \mathrm{F}$ in July and August.

The Quincy Basin is drained by Crab Creek. The creek flows westward into the basin and then southeasterly toward Moses Lake. Since the beginning of irrigation in 1952 (Tanaka and others, 1974), perennial flow in Lower Crab Creek is supported by overflow from Potholes Reservoir and discharge from wasteways that primarily are return flows from irrigation.

The 2010 population of the study area was more than 68,000 (Washington State Office of Financial Management, 2017). The largest city in the study area is Moses Lake, with a population of 20,366, followed by Ephrata $(7,664)$ and Quincy $(6,750)$. The dominant land use/land cover in the study area in 2006 (fig. 2) was planted/cultivated crops (49 percent), followed by shrubland (37 percent) and developed areas (3 percent) (Fry and others, 2011). Use of groundwater resources in the Quincy Basin began in the late 1800s, when groundwater was withdrawn for agriculture, stock watering, and domestic use. In the 1950s, the CBP began to deliver water diverted from the Columbia River at Grand Coulee Dam for large-scale agricultural development (Vaccaro and others, 2015). Subsequently, groundwater levels generally have risen in the shallow basin-fill sediments.

Although groundwater withdrawals have increased since the 1950s, surface-water irrigation systems supply most of the agricultural water demand in the study area. Water diverted from the Columbia River is distributed by the CBP through a system of canals and pipes, or buried drains (fig. 3). Irrigation water that is not transpired by crops, evaporated, or discharged to the Columbia River through drains and wasteways recharges the groundwater system.

\section{Previous Investigations}

Numerous previous investigations have contributed to the understanding of the hydrogeologic conditions and water resources in or near the Quincy Basin. These studies are discussed here, and the locations of these studies are shown in figure 4. A brief summary of each investigation is provided herein, and the reader is referred to the individual documents for more detailed information provided by the respective investigation.

Early studies of the Quincy Basin focused on generic hydrogeologic unit descriptions and quantifying the available groundwater in the underlying aquifers. One of the earliest published descriptions of the Quincy Basin was completed by Schwennesen and Meinzer (1918) (fig. 4). Based on direct field observations and about 250 groundwater-level measurements, the report detailed various features of the basin including geology, topography, climate, soils, and stream discharge, as well as the feasibility of pumping groundwater for irrigation. Taylor (1948) followed with descriptions of the water-bearing properties of the formations underlying the Quincy Basin, the availability of groundwater in these formations, and the overall changes in the groundwater elevations from 1916 to 1941. Mundorff and others (1952) supplemented the earlier work of Taylor by describing the geology, geologic structure and influence on groundwater, groundwater occurrence and conditions (recharge, discharge, quality, and availability), and a water-level network established in 1940 and expanded with an additional 100 wells during 1949-50. 


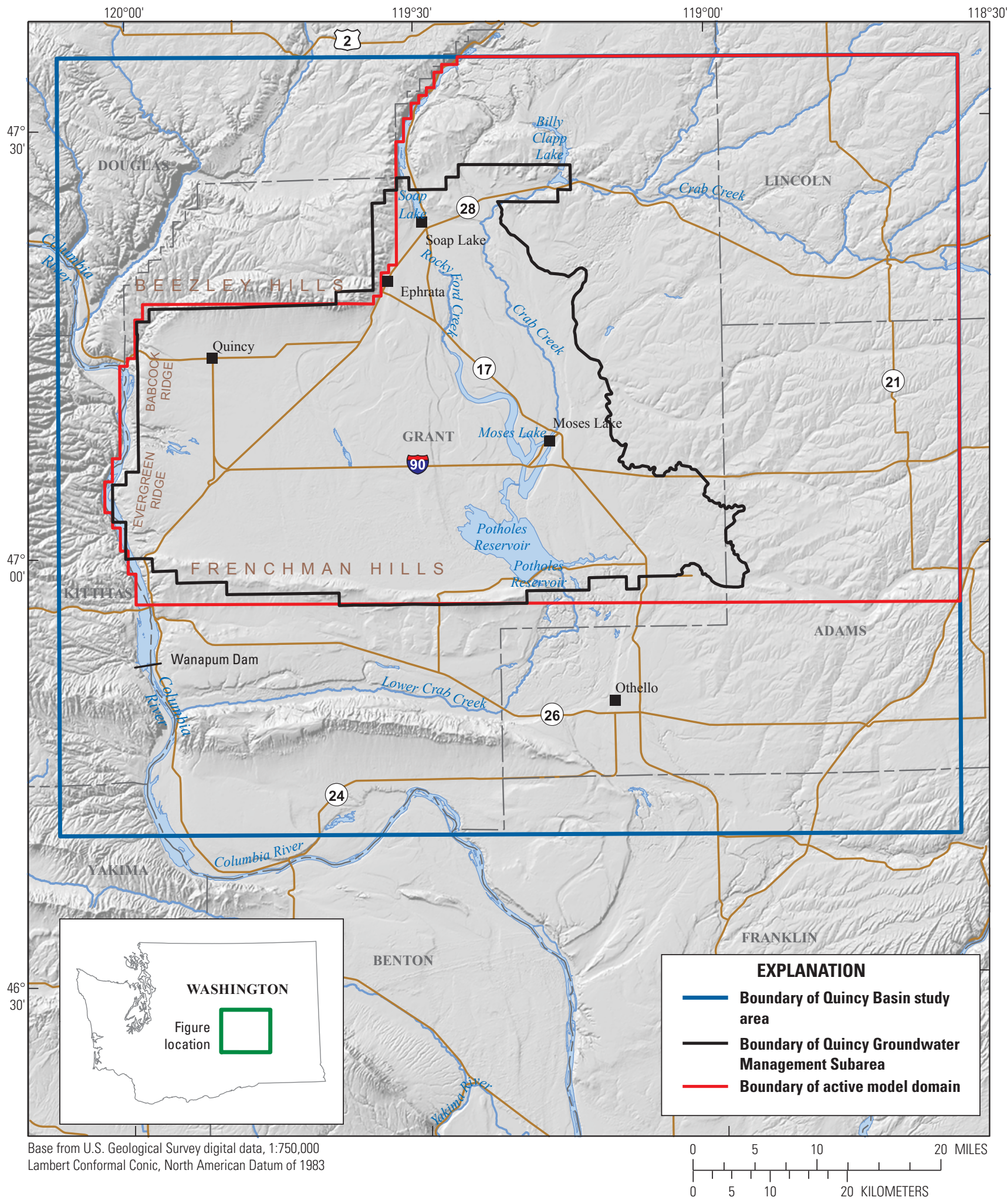

Figure 1. Location of the active model domain and the Quincy Groundwater Management Subarea, Quincy Basin, Washington. 


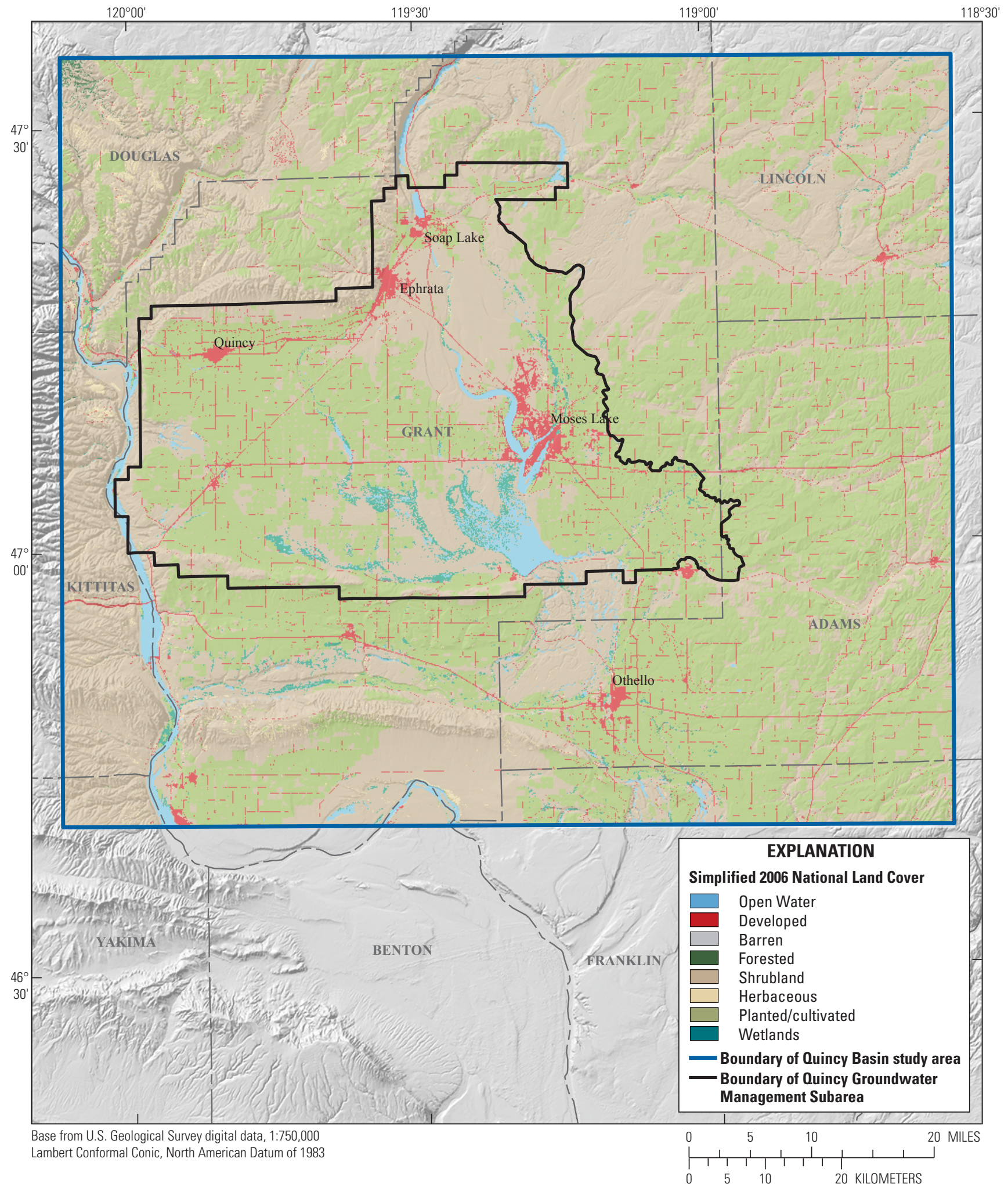

Figure 2. Simplified National Land Cover of the Quincy Basin study area, Washington, 2006. 


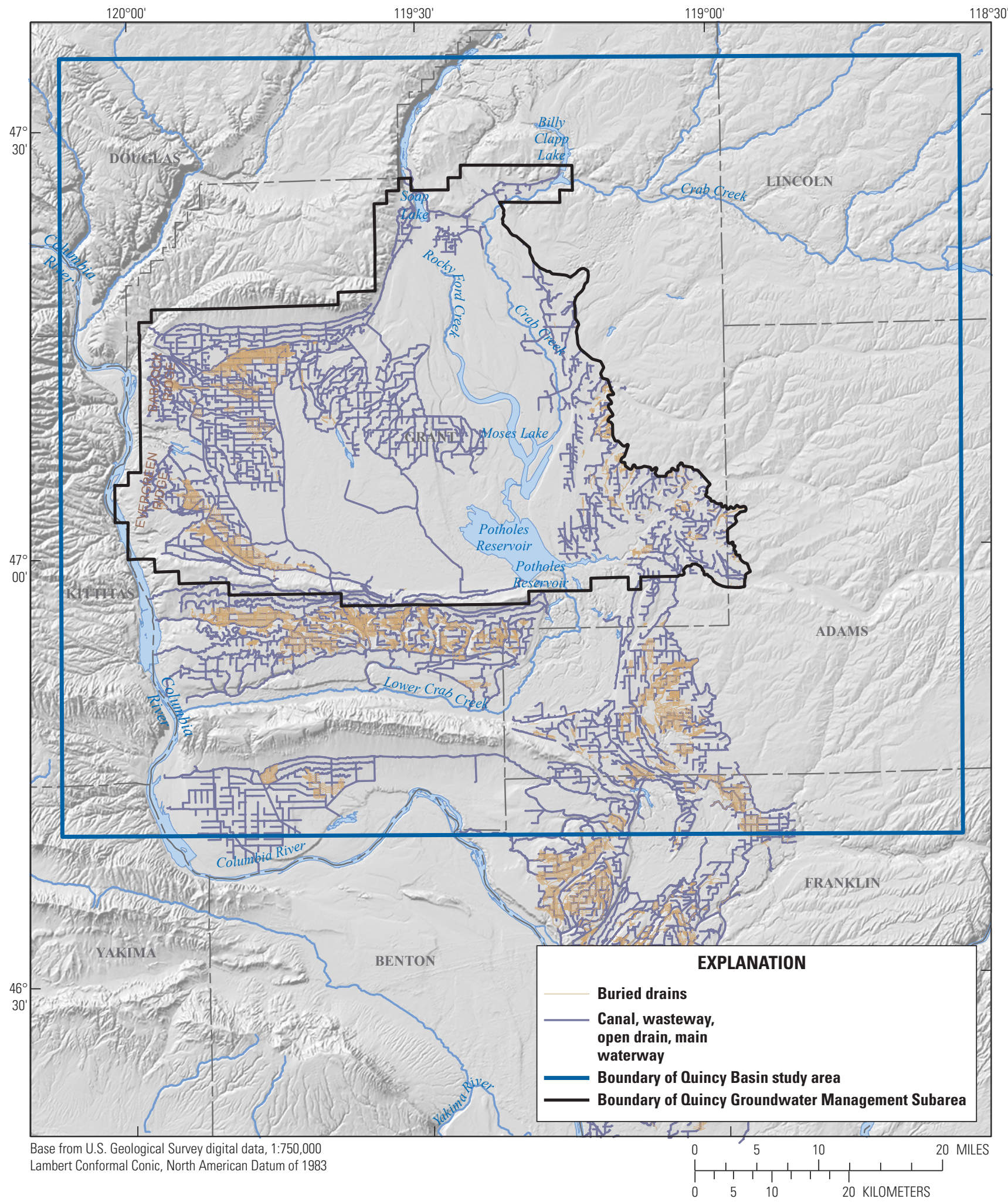

Figure 3. Locations of rivers, water-delivery infrastructure, and buried drains in the Quincy Basin study area, Washington. 


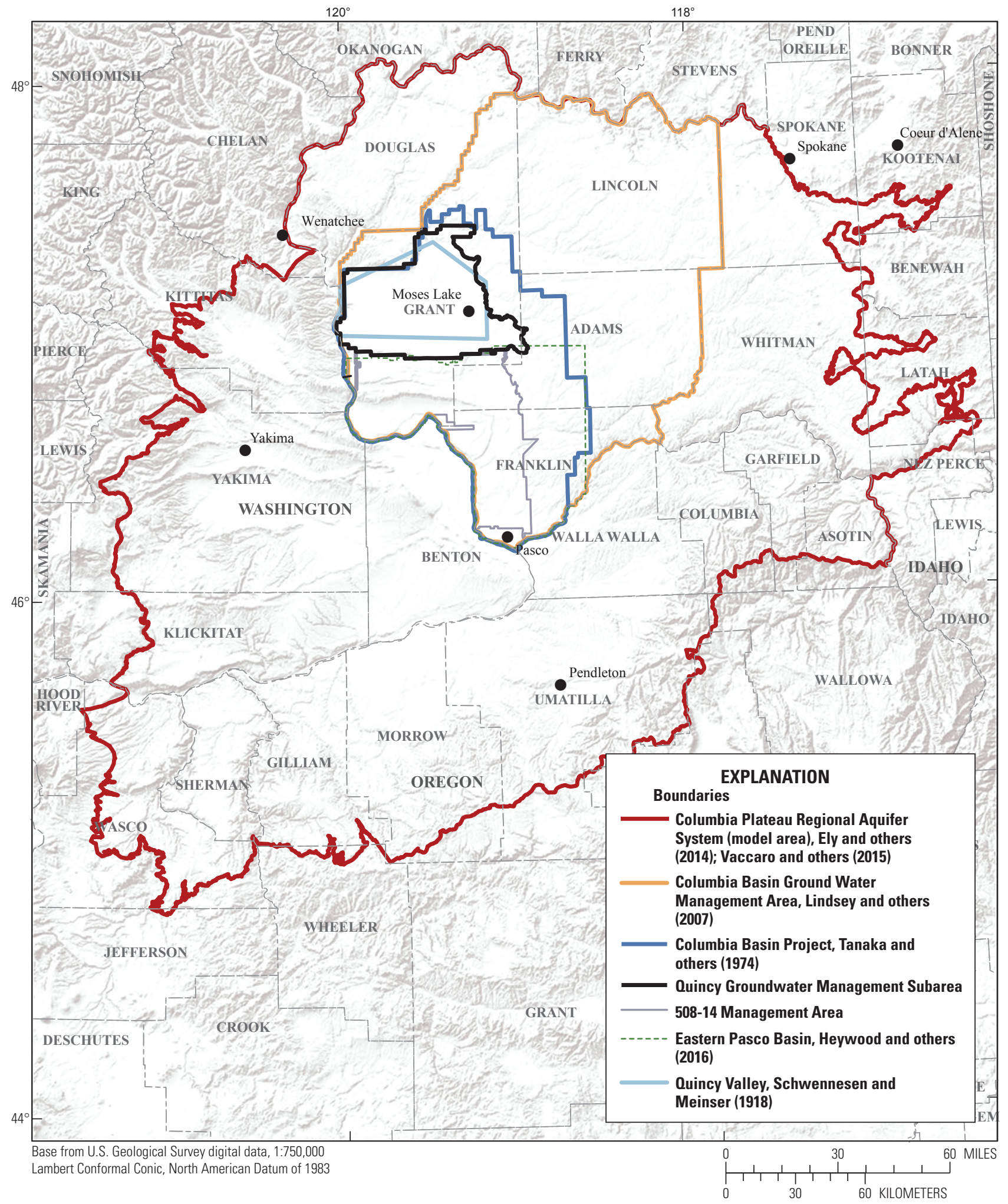

Figure 4. Locations of selected hydrogeologic studies of the Quincy Basin and selected adjacent areas, Washington. 
The establishment of the Columbia Basin Irrigation Project in the mid-20th century renewed interest in the Quincy Basin and the effects of irrigation on local aquifers. A two-volume report compiled by Walters and Grolier (1960) was among the first to document the effects of increased irrigation on groundwater levels by using hydrographs to predict areas of marked water-level rise. Tanaka and others (1974) (fig. 4) produced some of the first digital computer models of groundwater inflow and outflow in the Columbia Basin Irrigation Project area, including a model specific to the Quincy Basin. The analyses were divided into two parts: (1) a steady-state model analyzing conditions before 1952 (preirrigation), and (2) a transient model analyzing conditions after 1952 (post-irrigation). Results from these analyses outlined the differences in cumulated water storage amounts from the pre-irrigation to the post-irrigation era.

A series of reports were published in the 1980s and 1990s for the USGS Regional Aquifer-System Analysis (RASA) program for the Columbia Plateau area. Drost and Whiteman (1986) and Drost and others $(1990,1993)$ characterized the surficial geology, structure, top altitudes and thicknesses of hydrogeologic units, groundwater levels and groundwater quality, and various components of groundwater recharge and discharge for the Columbia Plateau Aquifer System RASA. Bauer and Vaccaro (1990) developed a deep-percolation model using precipitation, temperature, streamflow, soils, land-use, and altitude data to quantify groundwater recharge to this aquifer system for predevelopment and postdevelopment (1956-77) land-use conditions. Whiteman and others (1994) published a paper assessing several components including the hydrogeologic framework of the Columbia Plateau Aquifer System, the area water budget, regional groundwater flow patterns, and the general geochemistry of the aquifer system.

Lindsey and others (2007) described the geologic framework of the sedimentary aquifer system in the Columbia Basin Ground Water Management Area (GWMA) of Adams, Franklin, and Grant Counties (fig. 4). Several years later, a computer groundwater-flow model of the GWMA was completed by Porcello and others (2010).

Recent studies of the hydrogeologic framework, water budget, groundwater conditions, and post-development trends in the Columbia Plateau Regional Aquifer System encompass the current study area and focus on the basalt aquifers (Snyder and Haynes, 2010; Kahle and others, 2011; Burns and others, 2012; Vaccaro and others, 2015) (fig. 4). These studies provided important data used for the construction of a three-dimensional numerical model of groundwater flow in the Columbia Plateau Regional Aquifer System (Ely and others, 2014) (fig. 4). This model was used to evaluate groundwater availability as a result of the combined effects of irrigation-enhanced recharge, natural recharge by precipitation, groundwater withdrawal by pumping, and naturally occurring discharge in the form of streamflow and evapotranspiration.

Most recently, Heywood and others (2016) developed a model for groundwater storage changes in the 508-14 Management Area in the eastern Pasco Basin (fig. 4), just south of the Quincy Basin. The report describes groundwater flow directions and fluxes in the underlying aquifer system and quantifies the effect of anthropogenic inflow and outflow on storage in the system. A large component of the report also is dedicated to the simulation of four different hypothetical pumping scenarios in the 508-14 Management Area in an effort to quantify potential groundwater-level drawdown attributable to an increased demand for withdrawal.

\section{Methods of Investigation}

Data compilation and review for the purpose of refining the hydrogeologic framework in the Quincy Basin involved obtaining well driller's logs for lithologic and hydrologic information, analysis of water-level records, and the construction of hydrogeologic cross sections and hydrogeologic unit maps.

\section{Well Data}

Construction, lithologic log, and water-level data from 698 wells in the project area were compiled from 390 sites retrieved from the USGS National Water Information System (NWIS) database and 308 wells from the Ecology welllog database (Washington State Department of Ecology, 2016). The three criteria for selecting wells from the NWIS database were: (1) sites were located in the study area and were previously visited by USGS personnel, (2) complete construction information and well logs were available, and (3) multiple water-level measurements were available.

The 308 additional wells compiled from the Ecology well-log database were used in areas where NWIS well data were not available using the three well-selection criteria. These wells were not field-located and were assigned approximate latitude and longitude coordinates using the public land survey locations (township, range, section, and quarter-quarter section), well addresses, and (or) parcel numbers available on the drillers' logs for each well. Online maps provided by the Grant County Assessor and Adams County Assessor were used to verify drillers' locations and tax parcel numbers and to estimate latitudes and longitudes. Selected physical and hydrologic data for the project wells are provided in table 5 (at back of report). 


\section{Hydrogeology}

The surficial geology of the study area (fig. 5) was simplified by combining similar units from the digital geologic map database of Washington (Washington Division of Geology and Earth Resources, 2005). A map of the surficial hydrogeology of the study area was made by grouping surficial geologic units of similar lithology and extent into hydrogeologic units, refined further by using lithologic information from drillers' logs of project wells (fig. 6). A digital tabulation of borehole hydrogeologic unit assignments facilitated creation of seven hydrogeologic cross sections. Two representative sections are included in this report (fig. 7). Top and extent-of-unit maps of each hydrogeologic unit were manually drawn using information from the hydrogeologic units and the well data.

Raster representations of the top altitudes (surfaces) and extents of the hydrogeologic units described in this report were generated in a geographic information system (GIS) using a grid with square cells $100 \mathrm{ft}$ on a side. These surfaces were used to construct the digital hydrogeologic framework for the USGS modular three-dimensional finite-difference groundwater-flow model (MODFLOW; U.S. Geological Survey, 2018). Unit-top altitudes at project wells were interpolated through the extent of the hydrogeologic units using the Australian National University Digital Elevation Model (ANUDEM) procedure (Hutchinson, 1989). Each hydrogeologic unit surface was constrained where the unit outcropped by the National Elevation Dataset Digital Elevation Model (DEM; U.S. Geological Survey, 2017).

The interpolated hydrogeologic unit surfaces and thicknesses were compared to previous hydrogeologicunit maps and well interpretations to honor previous data interpretations wherever feasible. Hydrogeologic-framework uncertainties are greatest in areas where the surficial geology changes abruptly, or the project wells do not provide sufficient subsurface lithologic data. These interpolated hydrogeologic unit surfaces were used along with the borehole hydrogeologic unit assignments to create final cross section profiles using the GIS extension CrossView (https://crossviewgis.com/) (fig. 7).

\section{Horizontal Hydraulic Conductivity}

Hydraulic conductivity is a measure of the ability of a material to transmit water. Horizontal hydraulic conductivity was estimated for the hydrogeologic units using the drawdown/discharge relation reported on drillers' logs that reported pump testing wells for 1-120 h. Only data from those wells with a driller's log containing discharge rate, duration of pumping, drawdown, static water level, well-construction data, and lithologic log were used.

The modified Theis equation (Ferris and others, 1962) was first used to estimate transmissivity $(T)$ of the pumped interval. To determine transmissivity, the base Theis equation is rearranged and solved for $T$. Transmissivity is the product of horizontal hydraulic conductivity and thickness of the hydrogeologic unit supplying water to the well.

The modified equation is

$$
s=\frac{Q}{4 \pi T} \ln \frac{2.25 T t}{r^{2} S}
$$

where
$S \quad$ is drawdown in the well, in feet;
$Q \quad$ is discharge, or pumping rate, of the well, in cubic feet per day;
$T \quad$ is transmissivity of the hydrogeologic unit, in square feet per day;
$t \quad$ is length of time the well was pumped, in days;
$r \quad$ is radius of the well, in feet; and
$S \quad$ is storage coefficient, a dimensionless number, assumed to be 0.001 for confined units and 0.1 for unconfined units.

Assumptions for using equation 1 are that aquifers are homogeneous, isotropic, and infinite in extent; wells are fully penetrating; flow to the well is horizontal; and water is released from storage instantaneously. Additionally, for unconfined aquifers, drawdown is assumed to be small in relation to the saturated thickness of the aquifer. Although many of the assumptions are not precisely met, the field conditions in the study area approximate most of the assumptions and the calculated hydraulic conductivities are reasonable estimates for the defined hydrogeologic units.

Equation 1 was solved for transmissivity $(T)$ using Newton's iterative method (Carnahan and others, 1969). The calculated transmissivity values were not sensitive to assumed storage coefficient values; the difference in computed transmissivity between using 0.1 and 0.001 for the storage coefficient varies by a factor of 2 . The following equation was used to calculate horizontal hydraulic conductivity from the calculated transmissivity:

$$
K_{h}=\frac{T}{b}
$$

where

$$
\begin{gathered}
K_{h} \quad \text { is horizontal hydraulic conductivity of the } \\
\text { geologic material near the well opening, in } \\
\text { feet per day; and } \\
\text { is thickness, in feet, approximated using the } \\
\text { length of the open interval as reported in } \\
\text { the driller's report. }
\end{gathered}
$$

The use of the length of a well's open interval for $b$ overestimates values of $K_{h}$ because the equations assume that all the water flows horizontally within a layer of this thickness. Although some of the flow will be outside this interval, the amount may be relatively small because in most sedimentary deposits, vertical flow is inhibited by layering (Freeze and Cherry, 1979). 


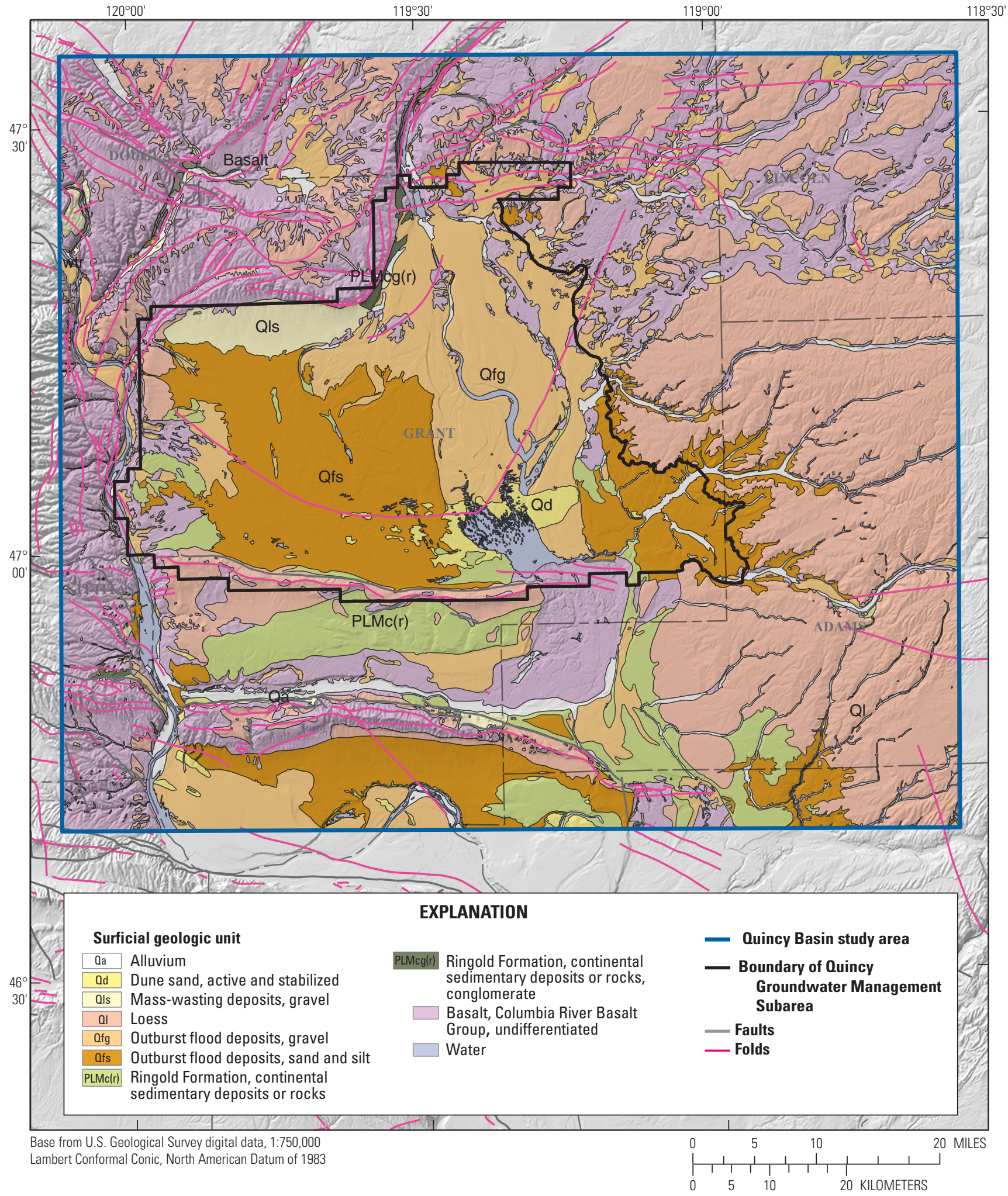

Figure 5. Simplified surficial geology of the Quincy Basin study area, Washington. Simplified from Washington Division of Geology and Earth Resources (2005). 


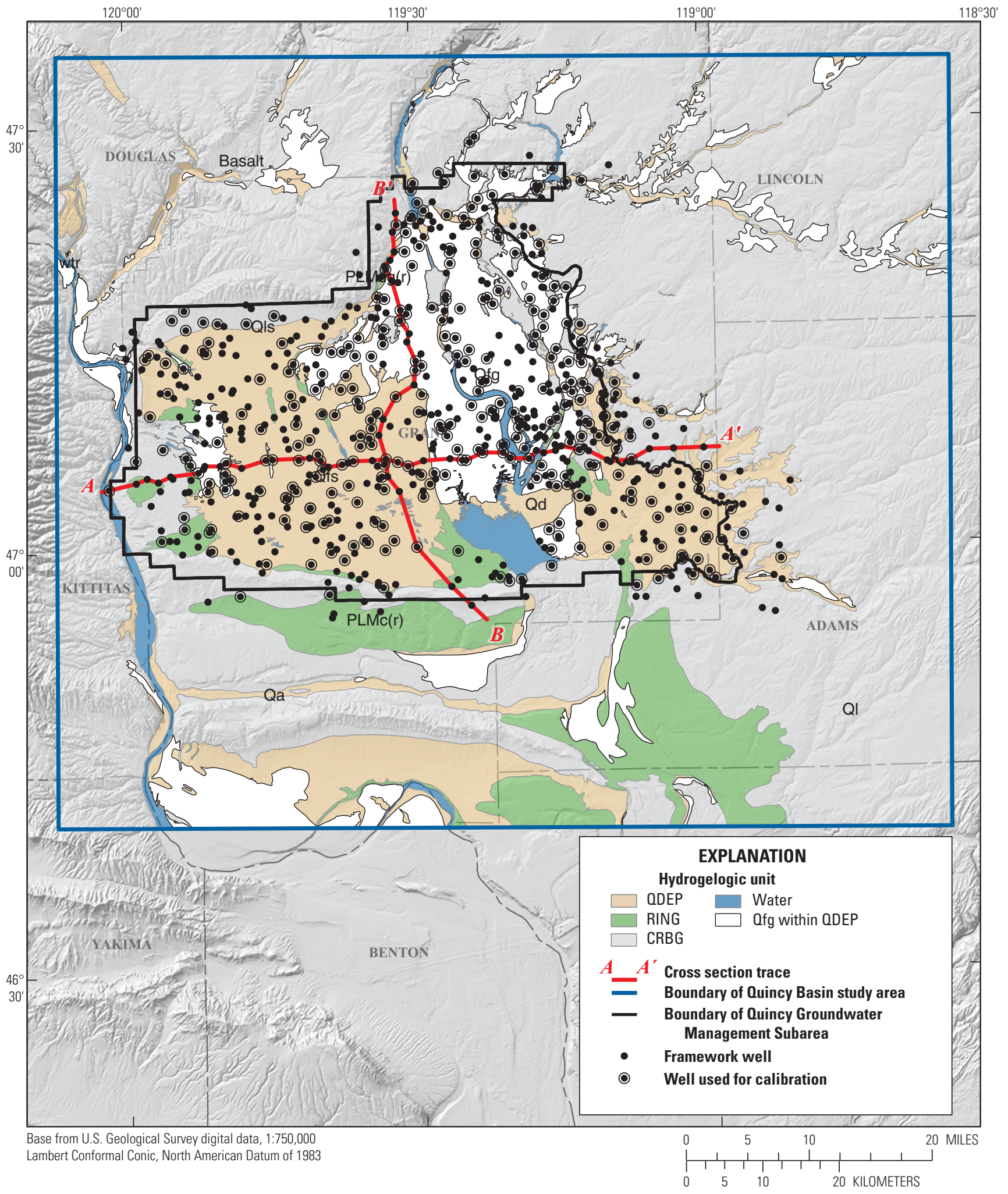

Figure 6. Surficial hydrogeology and locations of project wells of the Quincy Basin study area, Washington. Refer to table 1 for explanation of hydrogeologic units. 

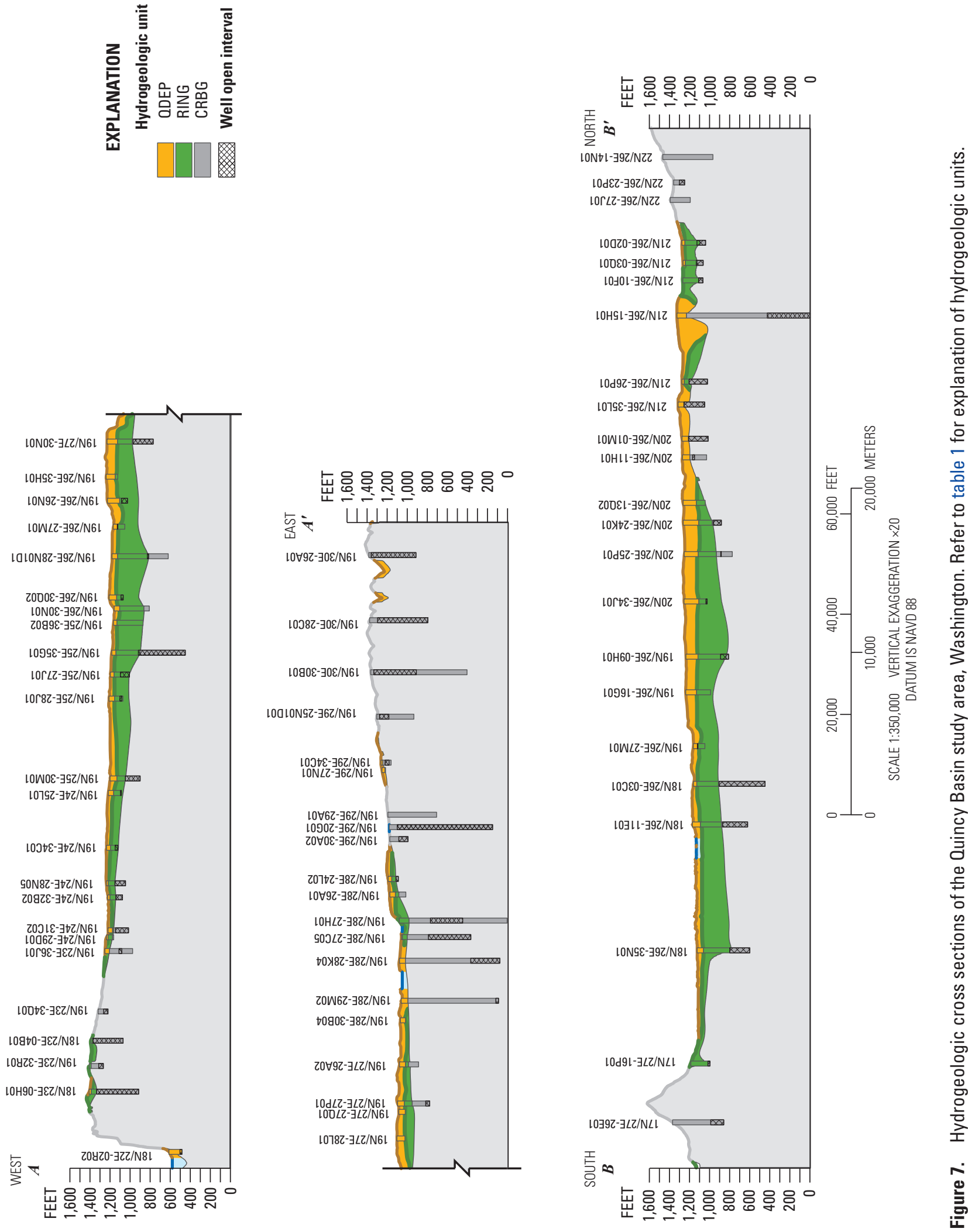
The resulting estimates of hydraulic conductivity using the methods described earlier in this section are presented in section, "Hydrogeologic Setting." The median values of estimated hydraulic conductivities for the aquifers are similar in magnitude to values reported by Freeze and Cherry (1979, p. 29) for similar materials. The estimates are biased toward the more productive zones in these units and may not be representative of the entire unit. The minimum hydraulic conductivities for the hydrogeologic units indicate that there are zones of low hydraulic conductivity in most units. Although many uncertainties are in the estimated values of hydraulic conductivity, these estimates provide an initial assessment of the relative differences in hydraulic conductivity between the different hydrogeologic units.

\section{Hydrogeologic Setting}

The Quincy Basin is a structural and topographic low in south-central Washington (fig. 1). The area is underlain by three major stratigraphic units in which most locally significant groundwater occurs. The stratigraphic units are, in ascending order: (1) the Columbia River Basalt Group (CRBG), (2) the Ringold Formation (RING), and (3) the sediments deposited predominantly by catastrophic proglacial flooding (QDEP) (table 1 and figure 6). The surficial geology of the study area is shown in figure 5 .

The geologic and hydrogeologic setting was previously described by Tanaka and others (1974) and Drost and others (1990) and is summarized here. During the Tertiary Period, flood basalts flowed intermittently into the region, resulting in a total basalt thickness in excess of 15,000 ft. Between eruptions, particularly those producing the younger flows, minor amounts of sediment (Ellensburg Formation) were interbedded with the basalts. Individual basalt flow tops and bottoms form productive water-bearing zones. Following the emplacement of the basalt flows, deformation took place in the form of northwest- to west-trending folds. The greatest degree of deformation was west of the study area and resulted in a series of folds known as the Yakima fold belt.

Folding and subsidence in the Miocene Epoch resulted in the deposition of fluvial and lacustrine sediments in the Quincy Basin by ancestral rivers and lakes that occupied the region. These sediments formed the Ringold Formation (Pliocene), which consists of sand, silt, and clay. The sandier zones of the Ringold have become saturated since irrigation began and now produce moderate well yields. During the late Pleistocene Epoch, glacial flood and melt water deposited gravels, sands, and silts throughout much of the study area. These floods scoured much of the earlier deposits, down to and into the basalts, and redeposited them in other locations. The resulting sediments form thick, productive aquifers where saturated. During the Quaternary Period, loess, dune sand, and alluvium were deposited on top of the older sediments or basalt. The geologic units were delineated into three generalized hydrogeologic units - QDEP, RING, and CRBGbased primarily on the textures and position of the geologic materials within the study area (table 1).

\section{Columbia River Basalt Group (CRBG) Hydrogeologic Unit}

The Columbia River Basalt Group (CRBG) hydrogeologic unit underlies the entire study area and occurs at land surface in the higher-altitude margins (figs. 5, 6). Five hundred fifty-four of the project wells are completed in the CRBG unit (table 1), where overlying sedimentary units (1) do not occur, (2) are insufficiently saturated, or (3) are unable to yield sufficient quantities of water to wells. The top altitude of the CRBG Unit (fig. 8) - which is based on the geologic map, project well logs, and hydrogeologic sections - was used for defining the base of the sedimentary hydrogeologic units. Manually drawn 100-ft contours of the buried basalt surface in the study area extent were combined with DEM landsurface altitudes where the basalt outcrops to generate a digital representation of basalt-surface altitude (fig. 8). The altitude of the basalt ranges from more than $3,000 \mathrm{ft}$ in the Beezley Hills to about $800 \mathrm{ft}$ near the center of the basin. The estimated horizontal hydraulic conductivity for the CRBG unit ranged from 0.3 to $770 \mathrm{ft} / \mathrm{d}$, with a median of $21 \mathrm{ft} / \mathrm{d}$, based on data from 81 wells open to the unit (tables 1 and 5).

The basalts form a complex series of aquifers and confining units at depth in the study area, in which most groundwater movement occurs in zones between basalt flows containing features such as flow breccia, rubble, and vesicles (Kahle and others, 2011). The principal basalt aquifer units in the study area are, from youngest to oldest, (1) the Saddle Mountains Basalt, (2) the Wanapum Basalt, and (3) the Grande Ronde Basalt. The upper surface of the basalts was refined for this study using depth-to-basalt data from the project well set and unit surface altitudes of the principal basalt aquifers mapped previously by Burns and others (2011).

\section{Unconsolidated Sedimentary Hydrogeologic Units}

Sedimentary hydrogeologic units, also referred to as overburden, include all the sediment that overlies the basalt, and consist of the Ringold Formation and Quaternary deposits. The thickness of this combined overburden (fig. 9) was calculated by subtracting the basalt-surface altitude (fig. 8) from the land-surface altitude. Overburden thickness is greatest (more than $400 \mathrm{ft}$ thick) in the center of the basin (fig. 9). 


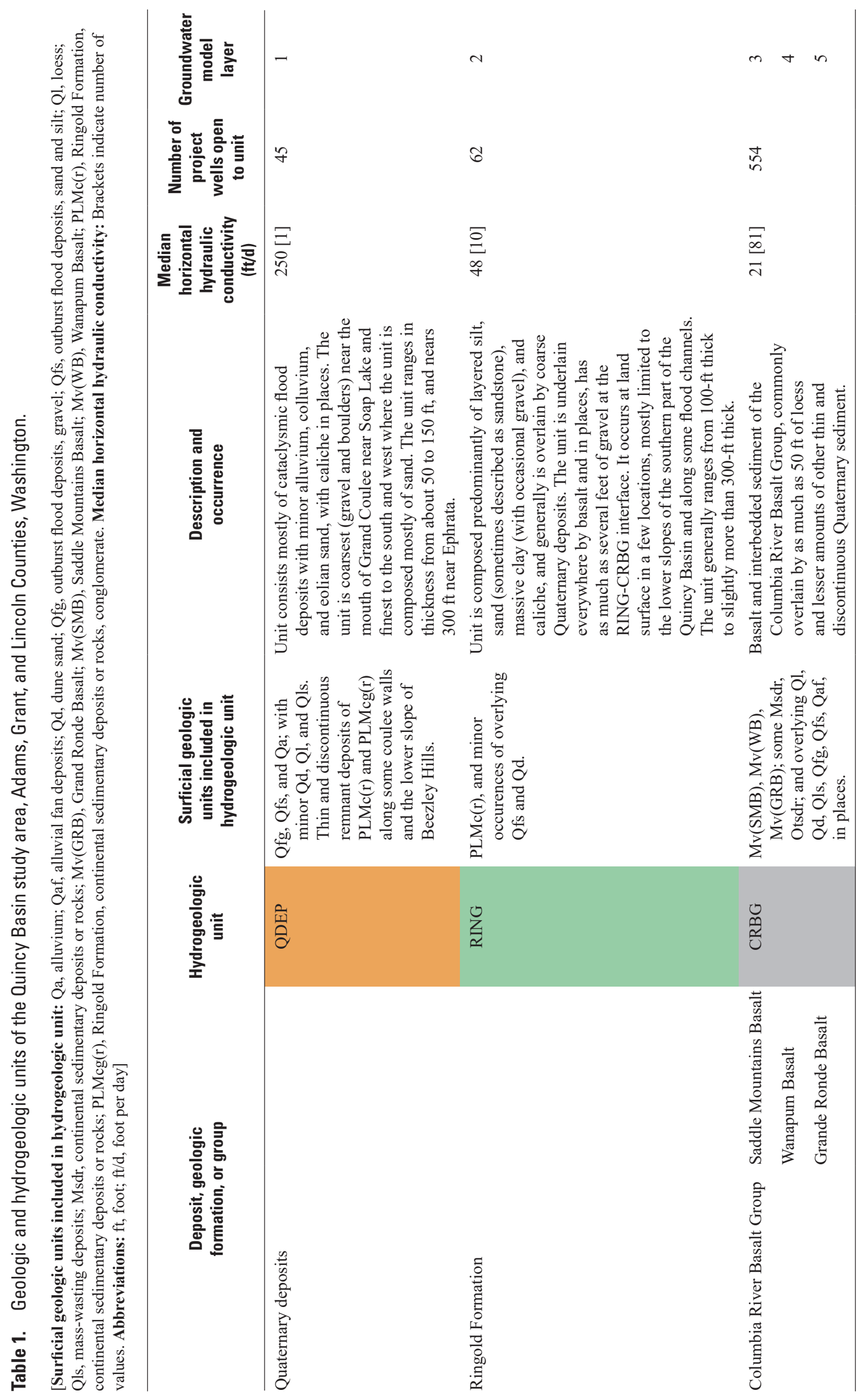




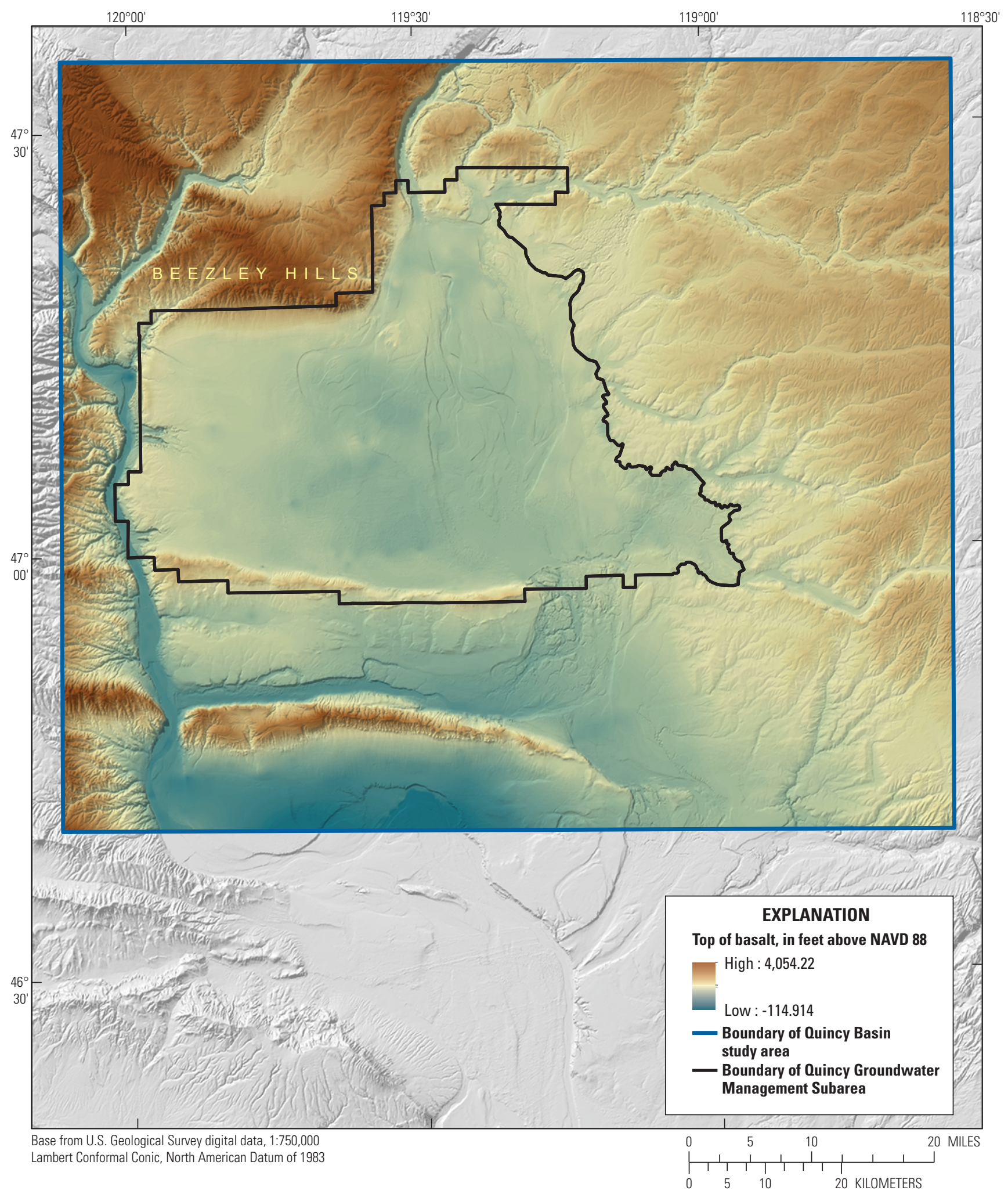

Figure 8. Top altitude of basalt surface in the Quincy Basin study area, Washington. 


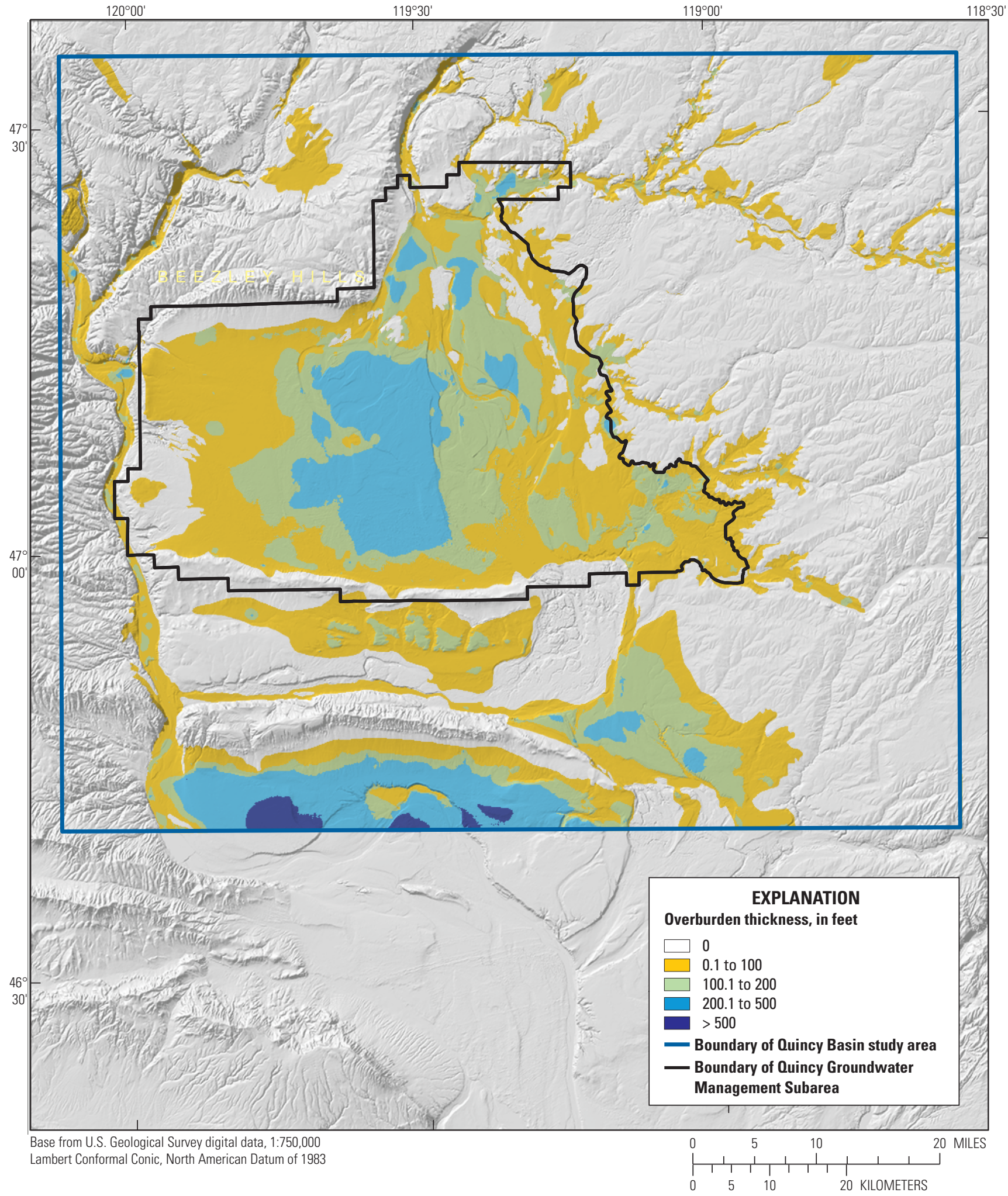

Figure 9. Extent and thickness of combined overburden units in the Quincy Basin study area, Washington. 


\section{Quaternary Deposits (ODEP)}

The Quaternary deposits (QDEP) consist primarily of cataclysmic flood deposits with minor alluvium, colluvium, and eolian sand, with caliche in places. The unit is coarsest (gravel and boulders) near the mouth of Grand Coulee near Soap Lake and finest to the south and west where the unit is composed primarily of sand. The unit generally ranges in thickness from 50 to $150 \mathrm{ft}$ but nears $300 \mathrm{ft}$ in places near Ephrata (fig. 7, cross section $B-B$ '). The QDEP unit occurs at land surface over most of the Quincy Basin (fig. 6). Although most project wells are completed in deeper hydrogeologic units, 45 of the project wells are completed in the QDEP where the unit is sufficiently thick and saturated to yield water to wells. The estimated horizontal hydraulic conductivity for well 18N/22E-02R02 (the only well completed in QDEP with available data to estimate hydraulic conductivity) is $250 \mathrm{ft} / \mathrm{d}$.

\section{Ringold Formation (RING)}

The Ringold Formation (RING) is composed predominantly of layered silt, sand (sometimes described as sandstone), massive clay (with occasional gravel), and caliche, and generally is overlain by coarse Quaternary deposits. The unit is underlain everywhere by basalt and, in places, has as much as several feet of gravel at the Ringold-CRBG interface. It occurs at land surface in a few locations, primarily limited to the lower slopes in the southern part of the Quincy Basin and along some flood channels (fig. 6). The RING unit generally ranges from 100 to slightly more than $300 \mathrm{ft}$ thick near the central part of basin (fig. 7). Despite the unit being primarily fine-grained, 62 project wells are completed in the unit (table 1) and provide usable quantities of water. The estimated horizontal hydraulic conductivity for the RING unit ranged from 20 to $290 \mathrm{ft} / \mathrm{d}$, with a median of $48 \mathrm{ft} / \mathrm{d}$, based on data from 10 wells open to the unit (tables 1 and 5).

\section{Hydrologic Setting}

\section{Recharge}

Prior to the 1950s, infiltration of precipitation was the primary source of groundwater recharge in the study area. Since the construction of the Columbia Basin Irrigation Project starting in the early 1950s, irrigation return flows have become a substantial source of additional groundwater recharge beneath agricultural areas in the Quincy Basin. The spatial distribution and temporal variation of recharge from precipitation and irrigation return flows to the Columbia Plateau Regional Aquifer System have been quantified using a monthly SOil WATer balance (SOWAT) model (Kahle and others, 2011). The SOWAT model uses simple relations among climatic, soils, land cover, and irrigation data to compute irrigation requirements and surplus moisture available for recharge. The SOWAT model incorporated evapotranspiration estimates derived from remotely sensed land-surface temperature data that were combined with other spatially distributed datasets including precipitation, soil moisture storage, and irrigation practices (Kahle and others, 2011). Estimated mean annual groundwater recharge for predevelopment (pre 1920) conditions in the Quincy Basin generally was less than $1.0 \mathrm{in} / \mathrm{yr}$, whereas during current conditions (2000-07), recharge was estimated at as much as $10.0 \mathrm{in} / \mathrm{yr}$ within the CBP (Ely and others, 2014).

\section{Historical Groundwater Levels}

Water levels measured during 1939-45 in wells screened in both overburden sediments and underlying basalt aquifers (fig. 10A) may be considered representative of the predevelopment conditions that were present before the construction of surface-water delivery infrastructure or substantial groundwater withdrawals. Groundwater flowed from the upland areas on the northeastern and northwestern parts of the basin; toward the central part of the basin; and then generally toward Crab Creek, Moses Lake, and what is now the Potholes Reservoir. Groundwater flow direction is determined by connecting a line perpendicular to the waterlevel contours and going from high to low elevations. Because the water levels mapped in figure 10 are a combination of measurements from both overburden and basalt aquifers, actual water-level gradients could differ between the overburden and basalt aquifers. Therefore, the directions of predevelopment groundwater flow may not be adequately represented in figure 10 for all areas.

Water levels in the basalt and overburden aquifers began to rise substantially in some areas following the development of surface-water delivery infrastructure and associated agricultural irrigation in the early 1950s. A hydrograph depicting a $200-\mathrm{ft}$ increase in water level (well 19N/23E34R01, fig. 10B) from 1957 to 1985 exemplifies the change in water levels measured beneath irrigated areas where both basalt and the overburden occur. 
A.

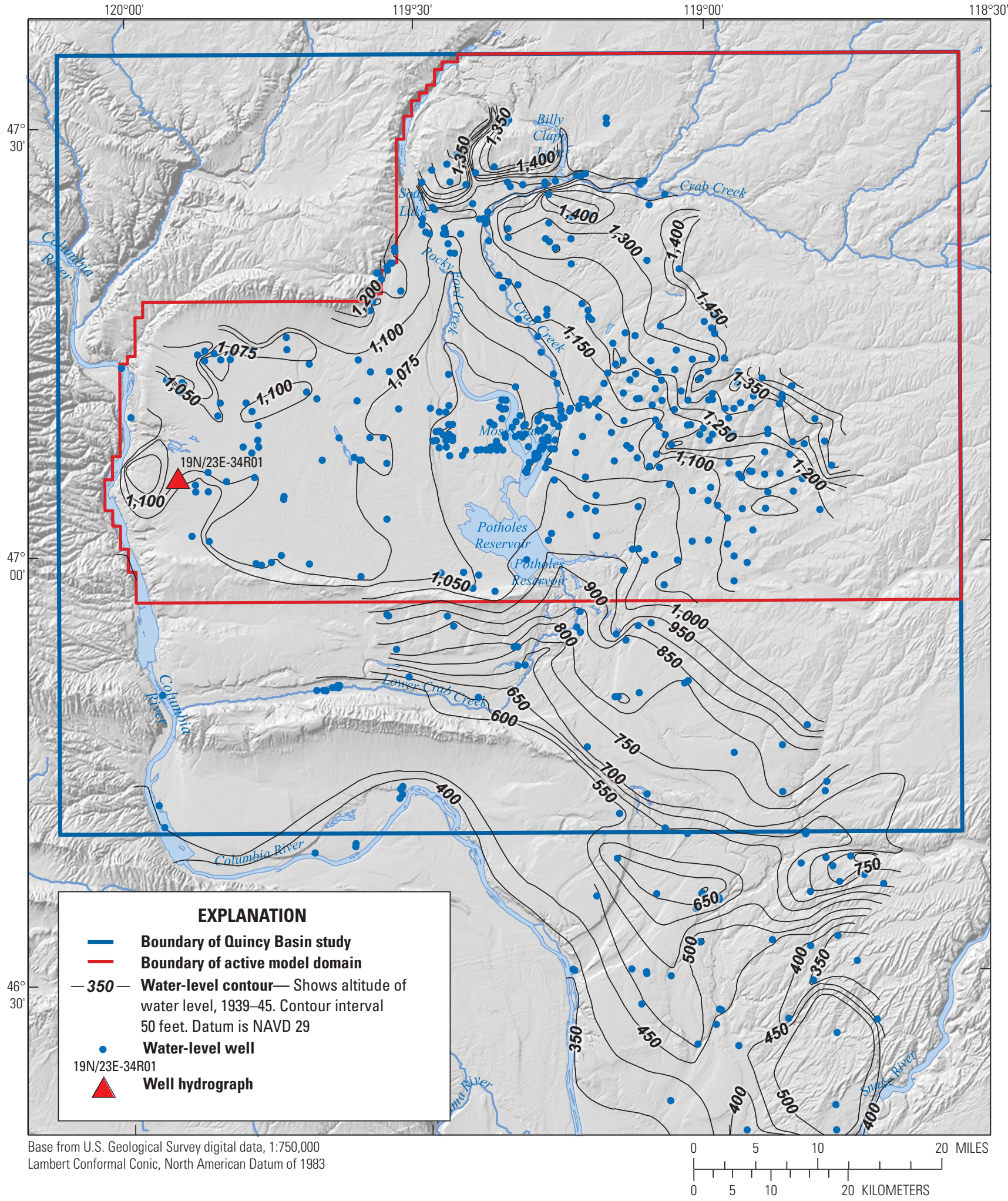

Figure 10. Contours of water levels measured in wells, 1939-45 (A); and hydrograph of well at location $A(B)$, Quincy Basin, Washington. 


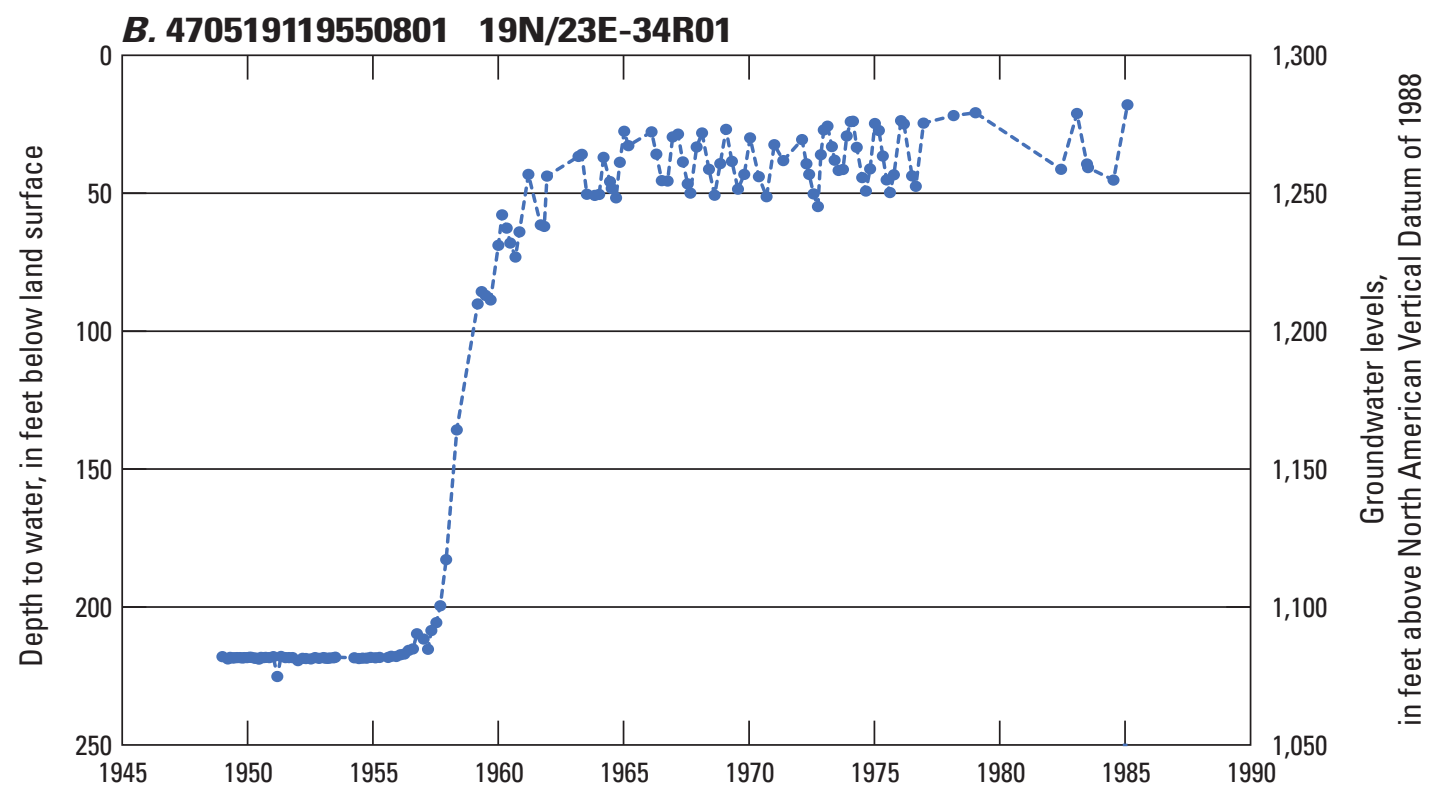

Figure 10.-Continued

\section{Simulation of Groundwater Flow}

The groundwater model developed in this study is based on a simple conceptual model in which natural precipitation and irrigation flows recharge the aquifer system by vertical flow through sedimentary overburden (where sediments occur) and into basalt layers. Regional groundwater-flow through basalt-aquifer layers occurs from areas to the north and east of the model domain and generally discharges to the Columbia River, although flow through the deepest basalt layers may discharge farther away. The model was designed to address a primary project objective - quantification of the spatial distribution of additional groundwater in storage resulting from agricultural development. The model also can be used to address secondary project objectives, which include assessments of various pumping and increased irrigation efficiency scenarios on groundwater levels.

\section{Numerical Method}

Simulation of a substantially rising water table, such as that which occurred in the Quincy Basin once irrigation of the area began, involves rewetting nonlinearities and associated numerical instabilities. The Newton formulation of the unconfined groundwater-flow equation available in MODFLOW-NWT (Niswonger and others, 2011) facilitates simulation of these systems, and, therefore, was selected to simulate the Quincy Basin.

\section{Spatial Discretization}

The model grid contains 101 rows and 117 columns of square finite-difference cells that are $1 \mathrm{~km}$ on a side (fig. 11). The grid was positioned so that the model cells correspond with the rasterized SOWAT model recharge and groundwaterwithdrawal data to enable the use of the SOWAT data to specify historical flow rates of recharge and groundwater withdrawals into and out of the model domain. The active model domain is east of the Columbia River, and encompasses $2,526 \mathrm{mi}^{2}$, or about 55 percent of the area covered by the rectangular finite-difference grid. Five model layers (table 1) represent the two hydrogeologic units in the sedimentary overburden and the three basalt units underlying them. The thicknesses of individual model layers vary spatially to represent the thickness of the Quaternary depositional unit, Ringold Formation, Saddle Mountains Basalt, Wanapum Basalt, and Grande Ronde Basalt. The upper $600 \mathrm{ft}$ of the Grande Ronde Basalt is represented by the lowest model layer. The spatial extents of the CRBG units were taken from Ely and others (2014). Although the five model layers generally correspond to these hydrogeologic units, the hydrogeologic units do not occur in all areas of the model domain. In order to simulate hydraulic connection between hydrogeologic units where a stratigraphically intervening hydrogeologic unit is not present, the absent units were assigned a 1-ft layer thickness and the specified hydraulic properties were changed to represent hydraulic conductivities of the layer below so that all layers are represented everywhere in the active model domain. This results in the simulated flow passing through the "altered" layer as if it were part of an adjacent model layer. Model layers 1-4 were simulated as convertible between confined and unconfined conditions. Layer 5 was simulated as confined. 


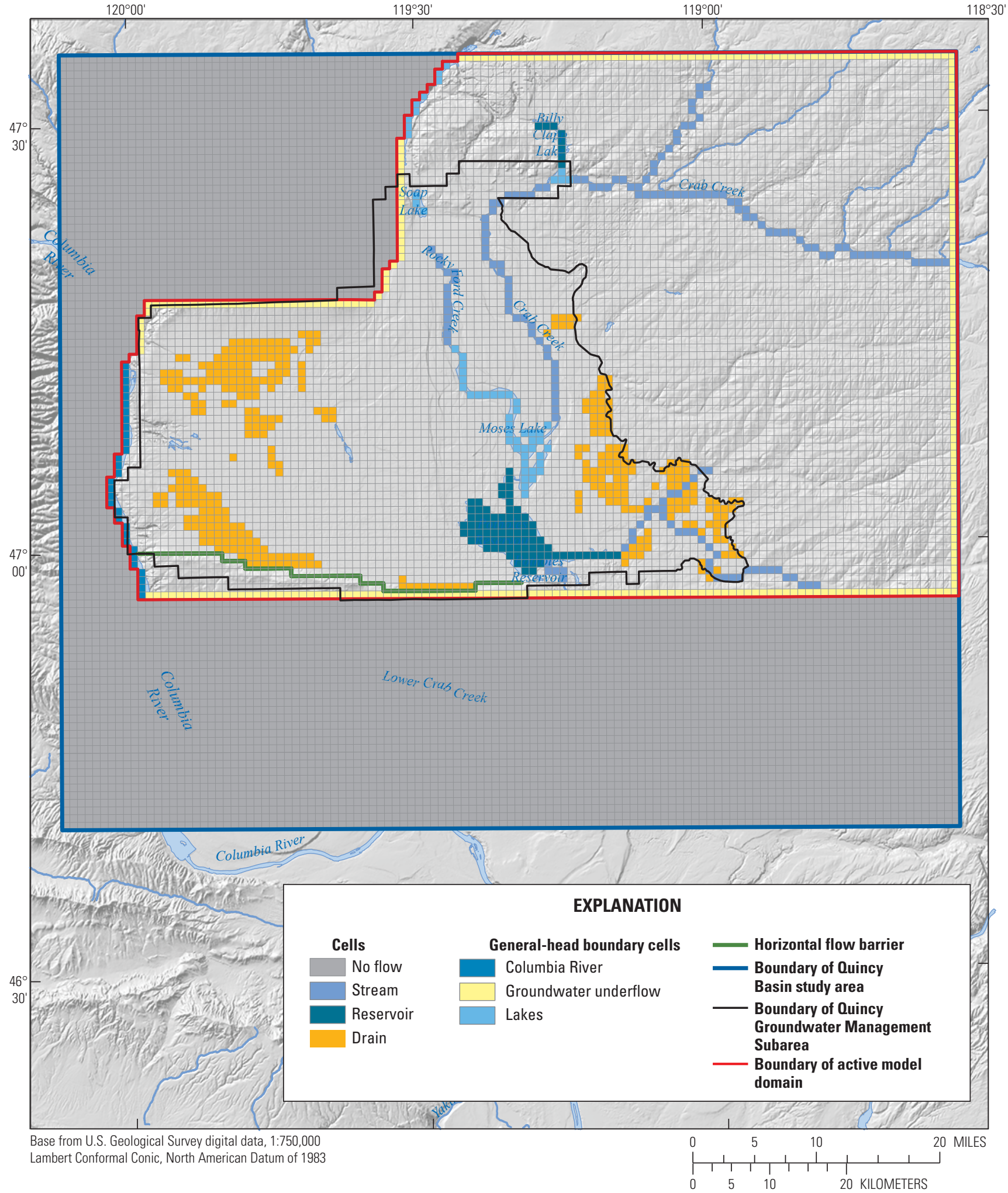

Figure 11. Finite-difference grid for the groundwater model with stream, reservoir, and drain cells; general-head boundary cells; and horizontal-flow barriers, Quincy Basin, Washington. 


\section{Time Discretization}

A steady-state stress period was used to simulate groundwater conditions in the Quincy Basin prior to 1920. Ninety-four annual stress periods encompass the time interval of January 1, 1920-December 31, 2013, that was used for calibration to observed water levels. These annual stress periods were selected to correspond to the temporal discretization of Ely and others (2014) from which the recharge and groundwater withdrawals of this model are specified. For the scenarios described in this report, the final transient stress period (2013) was run to steady-state conditions and model input was modified for the steady-state scenarios.

\section{Boundary Conditions}

Boundary conditions define the locations and manner in which water enters and exits the active model domain. Conceptually, water enters the aquifer system as recharge from precipitation and irrigation and through lateral groundwater flow and exits the system as discharge to the Columbia River and other streams, lateral groundwater flow, and groundwater pumpage. Three types of model boundaries were used: (1) no-flow boundaries (bottom and edges of the model), (2) headdependent flux boundaries (streams, drains, and general-head boundaries), and (3) specified-flux boundaries (pumpage and recharge).

\section{No-Flow Boundaries}

The lateral and bottom surfaces of the model domain are no-flow boundaries except for those lateral parts of the model domain that simulate groundwater underflow with headdependent flow boundaries (see section, "Head-Dependent Flux Boundaries").

\section{Specified Flux Boundaries}

Two types of specified fluxes were simulated in the model: (1) recharge and (2) groundwater withdrawals (pumpage).

\section{Recharge}

The annual recharge rates specified for the Quincy Basin model documented in this report came from the regional model of Ely and others (2014), which includes both natural and anthropogenic (for example, irrigation flows) components. Although the regional model of Ely and others (2014) uses larger $\left(3-\mathrm{km}^{2}\right)$ finite-difference cells, recharge for that model was computed with $1-\mathrm{km}^{2}$ raster arrays that are compatible with the $1-\mathrm{km}^{2}$ finite-difference cells of this model. Ely and others (2014) estimated natural recharge using gridded historical estimates of annual precipitation for the period 1895-2007; predevelopment recharge was estimated as the average natural recharge for this period, irrigation recharge and irrigation pumping were estimated using a remote-sensing based SOWAT model for 1985-2007 (Kahle and others, 2011), and pre-1985 irrigation recharge and pumping were estimated using previously published compilation maps and the history of large-scale irrigation projects. The recharge estimated for 2007 (fig. 12) was specified for all subsequent years of the simulation (2008-13). Because 2007 precipitation was similar to the mean annual precipitation (Kahle and others, 2011), extrapolation of the 2007 simulated recharge was a reasonable representation for subsequent years.

\section{Groundwater Withdrawals}

The groundwater withdrawals estimated with the SOWAT model used by Ely and others (2014) were used for this model and were simulated with the WELL package (McDonald and Harbaugh, 1988). Assignment of the SOWAT model-estimated groundwater withdrawals to appropriate depths likely introduces the greatest errors in the model because records of the actual location and magnitude of withdrawals are not available. For each stress period, the groundwater withdrawal estimated by the SOWAT model for each model cell was assigned to one or more wells (fig. 13). Well locations were obtained from the Washington State Department of Ecology well database. The total amount of pumping in each cell was split equally among the number of wells in the cell. If no well was in a cell with groundwater withdrawals, the groundwater withdrawals were distributed between layers based on the well depths from the next nearest cell that contained a well. Some structural model error was a byproduct of the specification of these specified groundwater withdrawals.

The magnitude of groundwater withdrawals from the study area was negligible until the 1930s, when it began to increase to about 10,000 acre-ft/yr by the early 1940s (fig. 14). Withdrawal rates increased rapidly from the mid-1960s through the mid-1980s-from about 50,000 acre-ft/yr in 1965 to more than 275,000 acre-ft/yr by 1985 .

\section{Head-Dependent Flux Boundaries}

Groundwater flows to rivers, streams and lakes, agricultural drains, reservoirs, and flow across the model perimeter depend on the hydraulic heads of those features and the aquifer groundwater levels, and, therefore, are simulated as head-dependent boundaries. 


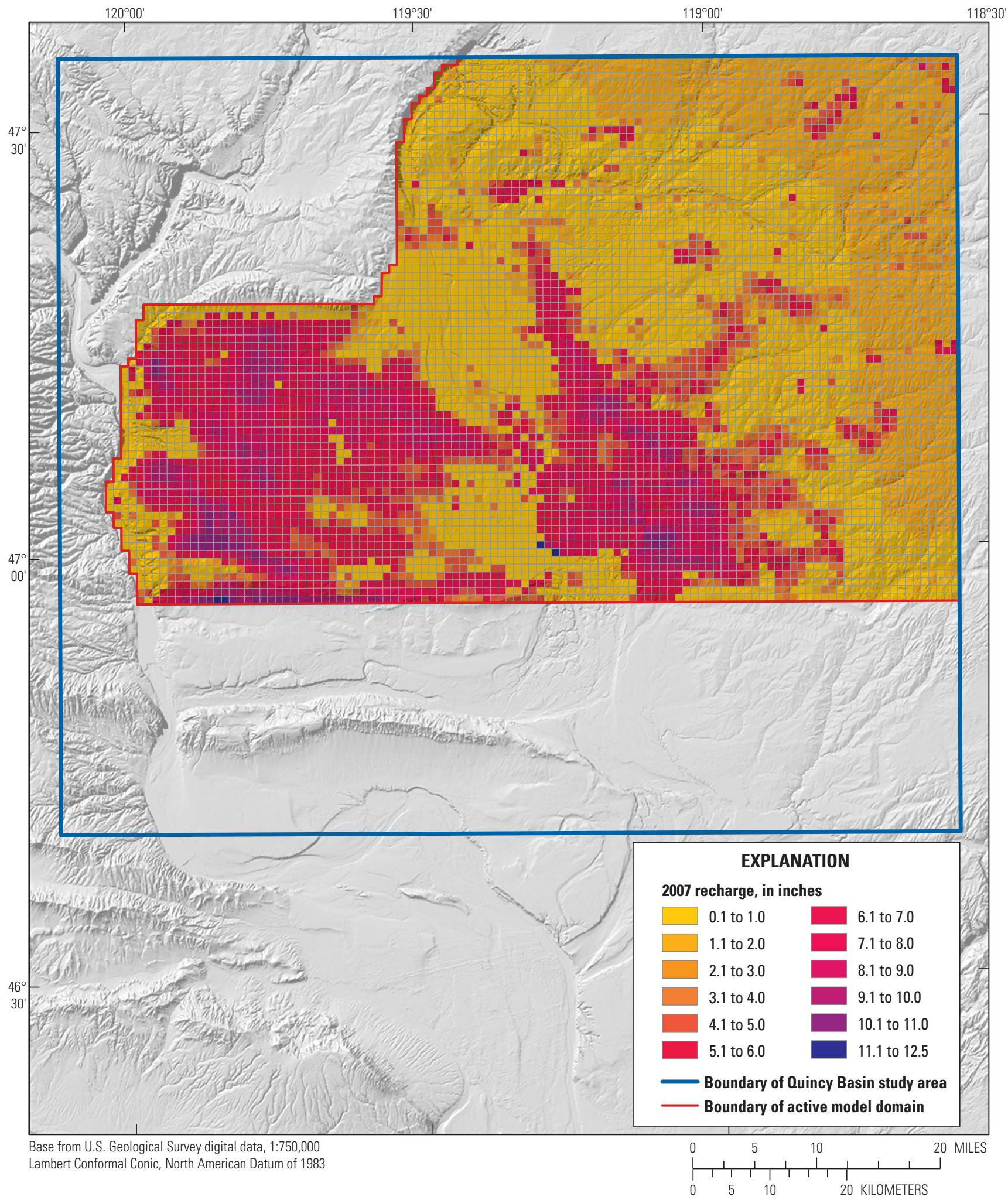

Figure 12. Distribution of recharge specified in the Quincy Basin model domain, Quincy Basin, Washington, 2007. 




Figure 13. Locations of simulated withdrawal wells and SOil WATer balance (SOWAT) model-estimated groundwater withdrawals, Quincy Basin, Washington, 2007. 


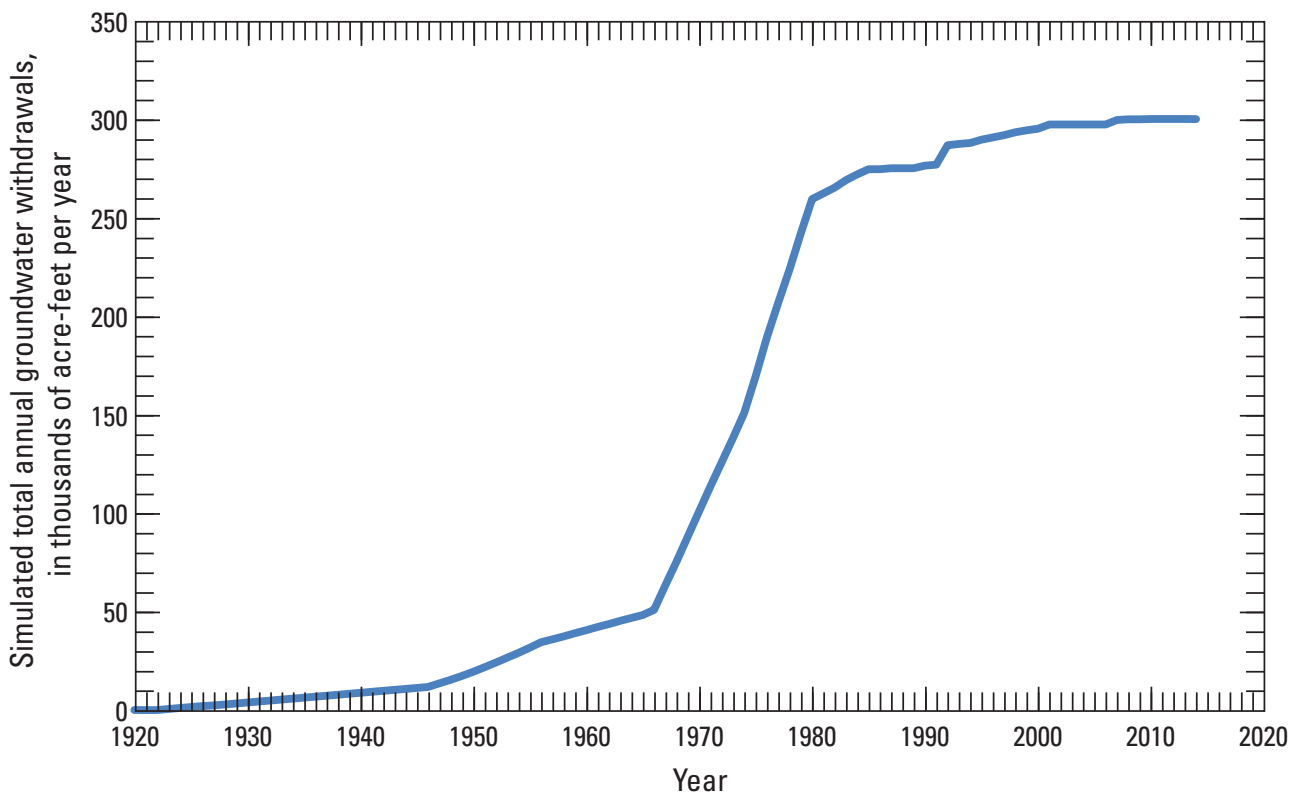

Figure 14. Total annual groundwater withdrawals simulated from the Quincy Basin, Washington, 1920-2014.

\section{General Head Boundaries}

The Columbia River bounds the western side of the model domain and was simulated with the General Head Boundary (GHB) package of MODFLOW (McDonald and Harbaugh, 1988) (fig. 11). The part of the Columbia River that borders the model domain was simulated without dams prior to 1963 . For simplicity, the stage change due to construction of the Wanapum Dam (fig. 1) was simulated to occur in 1963. River stages were set to $520 \mathrm{ft}$ prior to dam construction and $570 \mathrm{ft}$ afterwards based on topographical map information.

The underflow of groundwater in the CRBG through the northern, eastern, and southern perimeter of the study area was simulated at the locations in figure 11 with the GHB package. The GHB cells were connected to model layer 5, which represents the top of the Grande Ronde Basalt. Water levels specified for each of the groundwater underflow GHB cells in this model were taken from corresponding locations simulated in layer 36 (which represents the top of the Grand Ronde Basalt) during the steady-state, predevelopment stress period of the revised Columbia Plateau Regional Aquifer System (CPRAS) model (Ely and others, 2014).

The GHB package also was used to simulate subsurface exchange of water from certain naturally occurring lakes with the underlying aquifers (fig. 11). Representation of the lakes in this way allows flow into and out of a lake cell in proportion to the difference between the head in the cell and the specified head of the lake. The specified lake stages were determined from USGS 1:24,000-scale topographic maps because no data about changes in lake stages were available with the exception of Moses Lake. Stage data for Moses Lake was provided by Reclamation (Alexis Mills and Karl Williams, Bureau of Reclamation, written commun., 2017).

\section{Drains}

Agricultural drains (fig. 11) were simulated with the Drain (DRN) package of MODFLOW (McDonald and Harbaugh, 1988). The drain-boundary altitudes were specified as the minimum DEM land-surface altitude in the model cell containing the drain. Drain locations were obtained from Reclamation (Karl Williams, Bureau of Reclamation, written commun., 2017).

\section{Streams}

The part of Crab Creek within the model domain was simulated with the Streamflow-Routing (SFR) package of MODFLOW, as were other smaller naturally occurring streams in the model (fig. 11), to route streamflow and calculate stream-aquifer exchanges (Niswonger and Prudic, 2005). The model has 14 simulated stream segments that are coincident with the underlying MODFLOW cells (U.S. Geological Survey, 2014). 
The exchange of water between streams and groundwater is controlled by the difference in the groundwater level and stream stage in each cell, and by the hydraulic properties of the streambed at the river-aquifer boundary in each cell, which is represented in the model by a streambed conductance term. The depth of each stream within each reach was computed by SFR using Manning's equation for open channel flow assuming a wide rectangular channel, which is a reasonable approximation of channel geometry. For routing streamflow, a constant value of 0.04 was used for Manning's coefficient (Ely and Kahle, 2012).

\section{Reservoirs}

Two reservoirs, Potholes Reservoir and Billy Clapp Lake, were included in the model using the Reservoir (RES) package of MODFLOW (Fenske and others, 1996). The exchange of water between the reservoirs and groundwater is controlled by the difference in the groundwater level and reservoir stage in each cell, and by the hydraulic properties of the reservoiraquifer boundary in each cell, which is represented in the model by the conductance term of $0.01 \mathrm{ft}^{2} / \mathrm{d}$. Stage data for the two reservoirs was provided by Reclamation (Alexis Mills and Karl Williams, Bureau of Reclamation, written commun., 2017).

\section{Horizontal Flow Barriers}

The Frenchman Hills Fault (Lidke, 2003) acts as a barrier to groundwater flow and was simulated as a horizontal flow barrier (HFB; Hsieh and Freckleton, 1993) in model layers $1-4$ at the locations shown in figure 11 . The decreased hydraulic conductance between adjacent model cells is specified with a hydraulic characteristic for each HFB that is dimensionally equivalent to the hydraulic conductivity of the fault zone (in the direction perpendicular to the fault plane) divided by the width of the fault zone. A single hydraulic characteristic for HFBs representing the Frenchman Hill Fault barrier was parameterized and estimated during model calibration.

\section{Model Calibration}

Model calibration is the adjustment of model parameters within reasonable limits so that the differences (residuals) between measured and simulated groundwater levels are minimized with respect to an objective function. The calibration is assessed by examining how well the simulated quantities fit the measured quantities.

\section{Calibration Procedure}

The model was calibrated using a combination of traditional trial-and-error adjustments of parameters and the parameter estimation program (PEST; Doherty, 2005, 2006), enhanced with Pilot-Point Parameterization (Doherty, 2003; Doherty and others, 2010), Tikhonov Regularization (Doherty, 2003; Fienen and others, 2009), and Singular Value Decomposition (Doherty and Hunt, 2010). PEST automatically adjusted model parameters (horizontal and vertical hydraulic conductivity; specific storage; specific yield; and stream, drain, HFB, and general head boundary conductance) within specified limits through a series of model runs. After each model run, simulated groundwater levels were compared to measured values. Model runs continued until the differences (residuals) between simulated and measured values were minimized.

Pilot-point parameterization was used to represent spatial heterogeneity in horizontal and vertical hydraulic conductivity, specific yield, and specific storage. Pilot points were evenly distributed over the entire model domain by hydrogeologic unit and were used as surrogate parameters at which values for horizontal and vertical hydraulic conductivity were estimated during calibration. Estimated values of horizontal and vertical hydraulic conductivity and storage coefficients at pilot points were interpolated throughout the active model domain using kriging (a geostatistical algorithm) procedures in PEST. The result is a smooth variation of the hydraulic property over the model domain. Numerous studies have used pilot points for groundwater model calibration (de Marsily and others, 1984; LaVenue and Pickens, 1992; Petkewich and Campbell, 2007) and have proven them to be powerful, flexible tools for representing spatial heterogeneity in various types of aquiferhydraulic properties. 
Pilot points generally were spread in a regular grid pattern where possible. The pilot points were distributed vertically so that each hydrogeologic unit contained pilot points. If a pilot point for any given hydrogeologic unit occupied a location where that unit was absent, it was deleted from that location for that unit to ensure that the pilot points for each hydrogeologic unit were kriged only to other points within that unit.

\section{Water-Level Observations}

The model-calibration dataset included a total of 4,064 water levels measured in 710 wells with screen interval information. Although only a single measurement was recorded from some wells, multiple measurements from many of the wells constituted water-level hydrographs of as much as 68 years in duration. The calibration data set included 377 water-level measurements that were used to construct the map of predevelopment water levels (fig. 10A) that were located within the active model domain to represent the 1939 watertable altitude. No depths were available for wells shown in figure $10 \mathrm{~A}$, so the water levels were assigned to the whichever hydrogeologic unit was at the surface where the well was located.

The weight $(\omega)$ assigned to observations should represent the measurement error, and typically is computed as the inverse of the total observation-error variance. Substantial differences in measurement errors of the water levels were unable to be determined, and, therefore, were assumed to be equivalent, which resulted in uniform weighting among the water-level observations.

\section{Final Parameter Values and Sensitivities}

The ability to estimate a parameter value during the calibration process is related to the sensitivity of the modelsimulated output to changes in the parameter value. For example, if a parameter has a high sensitivity, the observation data effectively estimate the value. For parameters with low sensitivity, changes in the value have little effect on the modelcalibration process. Insensitive parameters may or may not be close to their corresponding field values and are not likely to be estimated accurately during the parameter-estimation process.

Relative composite sensitivities are a measure of composite changes in model outputs that are caused by small changes in the value of a modeled parameter (Doherty, 2005). For a given modeled parameter, the larger the value of the associated relative composite sensitivity, the more sensitive the model is to that parameter. Relative composite sensitivities were calculated and analyzed for the parameters used in the model-calibration process (table 2). Median sensitivities are presented for each hydrogeologic unit for the horizontal and vertical hydraulic conductivities, the storage coefficients, and other parameters.

The simulated water levels were most sensitive to parameters representing the groundwater flow to the Columbia River and groundwater underflow across the southern and northwestern model perimeter (GHB conductances). The simulated groundwater levels were most insensitive to the vertical hydraulic conductivity of the Quaternary deposits, the storage coefficients of the three basalt layers, and the GHB conductances of some of the lakes.

The calibrated values of the model parameters representing aquifer hydraulic conductivity, storage, and boundary and fault conductances are tabulated in table 2. The median calibrated values of hydraulic conductivities and storage coefficients are similar to corresponding values in other studies (Ely and others, 2014; Heywood and others, 2016). 
Table 2. Parameter sensitivities and final values for all parameters used in calibration of groundwater model for Quincy Basin, Washington.

[Specific yield pilot points: Specific yield numbers are not adjusted by parameter estimate code PEST. Abbreviation and symbol: GHB, General Head Boundary; -. not computed]

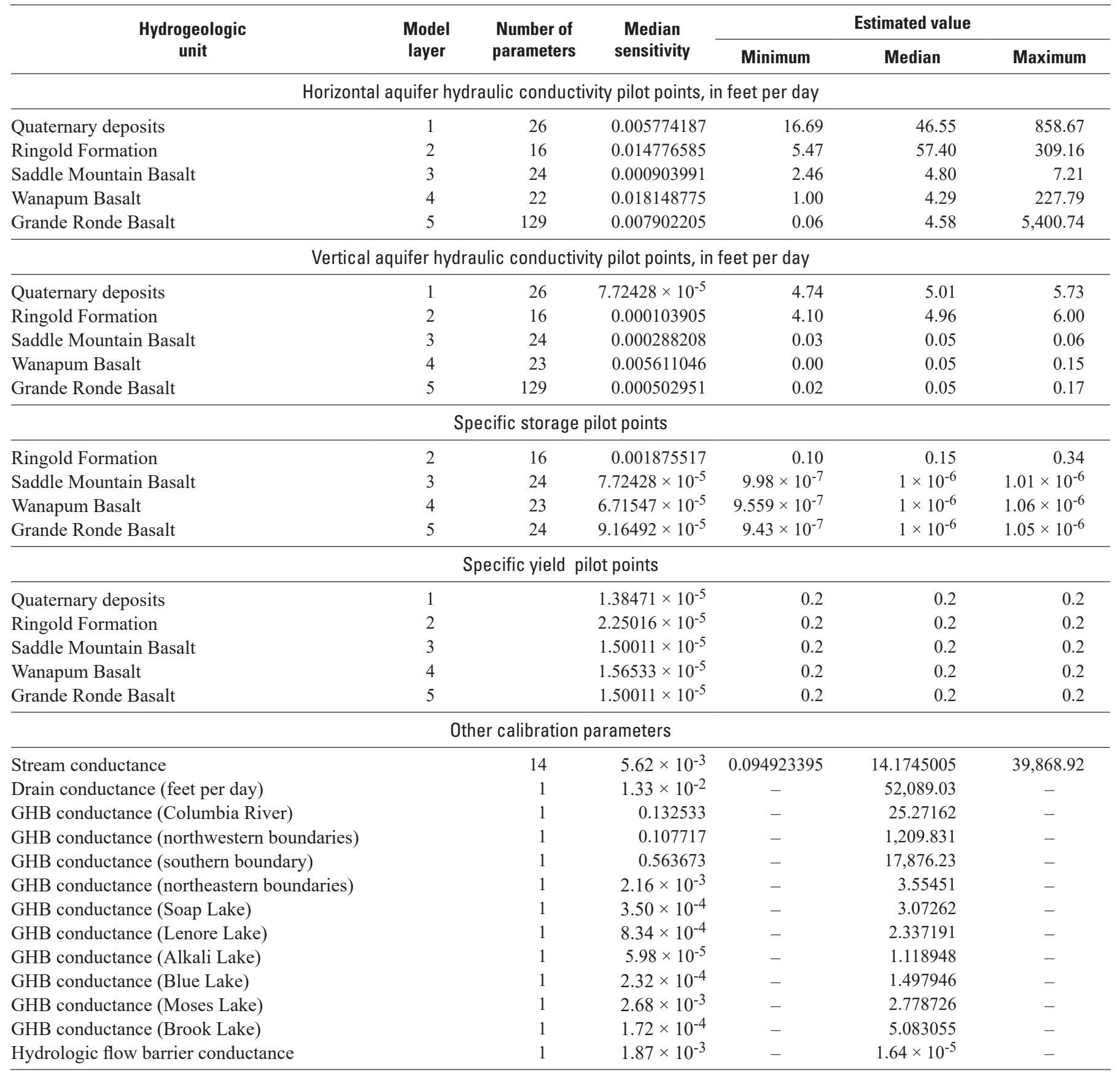




\section{Assessment of Model Fit}

A graphical and descriptive comparison of simulated and measured groundwater levels provides a clear insight into the model fit and complements the statistical measures of model fit. Such a comparison indicates how well the model replicates the flow system. It is important to determine that the model accurately simulates the regional direction and amounts of flow in the groundwater-flow system.

\section{Comparison of Measured and Simulated Hydraulic Heads}

The results of the calibration were assessed by comparing measured and simulated groundwater levels and by examining the mean and standard deviation of residuals (unweighted) and the root mean-square error (RMSE) of residuals for the groundwater levels. The mean of residuals represents the average difference between all measured and simulated values (residuals), and the sign of the mean of residuals (bias) indicates whether the model is overpredicting or underpredicting values (negative and positive mean of residuals, respectively). The standard deviation of residuals is a measure of how much variation there is in residual values greater than and less than the mean residual value. A low standard deviation indicates that the residuals tend to be close to the mean, whereas a high standard deviation indicates that residuals are spread out over a large range of values around the mean. The RMSE of weighted residuals provides a measure of variation that considers measurement accuracy. The RMSE of the difference between simulated and measured hydraulic heads in the observation wells, divided by the total range in water levels in the groundwater system (Anderson and Woessner, 1992, p. 241), also should be less than 10 percent to be acceptable (Drost and others, 1999).

The RMSE and the standard deviation of the residuals were 47.61 and $47.59 \mathrm{ft}$, respectively. The scaled RMSE was 0.048 ( 4.8 percent) and was obtained by dividing the RMSE of the residuals by the 1,001-ft range of observed water levels. Overall, because the groundwater levels have a RMSE divided by the total range of values of less than 10 percent, the model has a good fit (Drost and others, 1999). The mean error, calculated as the mean of the residuals (measured minus simulated water levels), was $-1.38 \mathrm{ft}$, indicating that overall simulated water levels are slightly higher than observed water levels. The mean absolute error (the mean of the absolute value of the residuals) was $36.02 \mathrm{ft}$.

A plot of measured compared to simulated groundwaterlevel altitudes provides a useful graphical assessment of model calibration (fig. 15). Measured compared to simulated values should plot close to a line with a slope of 1.0 and an intercept of zero. This diagonal line represents perfect agreement between measured and simulated values (the line of equal measured and simulated values), and the magnitude of the residual (difference between measured and simulated values) is indicated in the distance of the value above or below the line. Positive residuals (measured value is greater than simulated) and negative residuals (measured value is less than simulated) plot above and below the line, respectively.

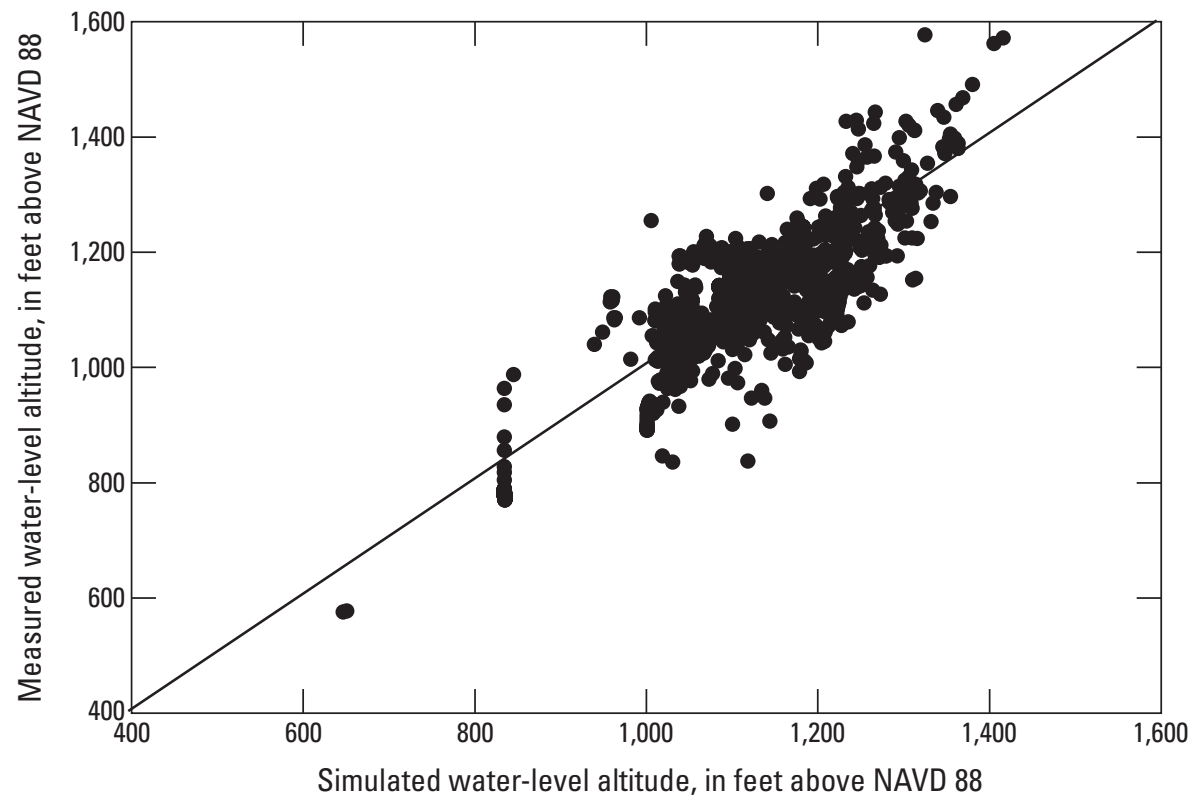

Figure 15. Measured compared to simulated water levels in the Quincy Basin, Washington. 
Measured compared to simulated values shown in figure 15 generally are along the line of equal measured and simulated values, indicating a good model fit; groundwater-level altitudes above $1,300 \mathrm{ft}$ tend to be underpredicted in some areas with high water levels. Some model bias is indicated by this deviation from a random residual distribution.

A spatial comparison of simulated and measured hydraulic heads indicates that the model reasonably simulates the measured groundwater levels (fig. 16). The residuals are calculated by subtracting the simulated heads from the measured heads, so positive residuals are at sites where the model predicts heads that are lower than measured (underprediction), and negative residuals are at sites where the model predicts heads that are higher than measured (overprediction). The smaller the residuals, the better the model is at predicting the water levels. The spatial distribution of the hydraulic-head residuals does not indicate any major patterns of bias, with the exception of the Moses Lake area and north along Crab Creek where the values tend to be overpredicted.

\section{Simulated Water Levels}

The general directions of simulated groundwater flow during 2013 may be inferred from contours of water-level altitudes simulated for 2013 (fig. 17). Groundwater generally flows either towards Crab Creek, Moses Lake, and Potholes Reservoir or towards the Columbia River, as the main discharge areas of the model. The highest water levels occur in the northeastern corner of the model.

The simulated rise in groundwater levels since 1920 in areas of the Quincy Basin primarily is a function of the magnitude of groundwater recharge and groundwater withdrawals in the area. Groundwater levels have risen substantially (generally from $50 \mathrm{ft}$ to as much as $250 \mathrm{ft}$ ) in the western part of the study area (fig. 18), where simulated recharge is primarily $5-10 \mathrm{in} / \mathrm{yr}$ (fig. 12). The unconsolidated sediments in these areas generally were unsaturated prior to irrigation occurring in the area. Water levels also have risen 25-100 ft in the central part of the study area and occur where simulated recharge primarily is $5-10 \mathrm{in} / \mathrm{yr}$. The highest waterlevel increases occur south of the hydrologic flow barrier that represents the Frenchman Hills Fault along the southern edge of the model. Simulated water levels have increased in that region by $250 \mathrm{ft}$ to more than $400 \mathrm{ft}$ in an area that receives as much as $12.5 \mathrm{in} / \mathrm{yr}$ of simulated recharge. The water levels in that area may be subject to larger uncertainties as there is only a small sliver of land between the horizontal flow barrier and the southern boundary of the model. Little calibration data are available to verify the water-level increases in that area. Some areas of the model (particularly a large swath in the eastern half) have had slight simulated water-level declines of less than $20 \mathrm{ft}$, with a small region having simulated declines of 20-40 ft presumably due to increased groundwater pumping. The largest simulated declines of more than $40 \mathrm{ft}$ occur in the model cells that contain Billy Clapp Lake (fig. 18) and are due to structural model error and are not considered to be realistic. Further spatial refinement of the model grid and hydraulic parameters would be needed to more accurately simulate changes in water levels near Billy Clapp Lake.

\section{Simulated Groundwater Budgets}

The net flows (inflow minus outflow from the model domain) of groundwater-model components were calculated for each model stress period (fig. 19). Prior to the mid-1940s, variations in annual precipitation resulted in small amounts of recharge (generally less than 2 in/yr) and relatively modest changes in storage. Note that increased groundwater storage is an outflow from the groundwater-flow system and is negatively signed; increasing negatively signed absolute values of storage in figure 19 indicate increases in the quantity of stored groundwater. From the late 1940s through the mid1960s, increased anthropogenic recharge due to irrigation and the leakage of water from Potholes Reservoir substantially increased groundwater storage in the aquifer system. Increasing groundwater withdrawals (pumpage) since the mid-1960s have abated further contributions to storage, with changes in storage stabilizing since about 1980 . Net changes to groundwater storage since 1980 have resulted primarily from variations in groundwater recharge caused by changes in annual precipitation.

The simulated groundwater budgets in the Quincy Subarea calculated for the initial steady-state stress period (which represents average "predevelopment" conditions prior to 1920) and the last transient stress period (which represents the year 2013) are summarized in table 3. During the initial steady-state conditions, vertical recharge, lateral groundwater flow from the surrounding area, and some seepage from streams into the subarea were balanced by discharge to streams, and lateral groundwater flow out through the downgradient Quincy Subarea boundary (fig. 11). By 2013, substantially more recharge into the area compared to the initial conditions (as well as inflow from the reservoirs) resulted in increased discharge to streams, lakes, and drains, and increased lateral groundwater flow out of the subarea. Groundwater withdrawals from wells were the largest outflow from the subarea. The distribution of both recharge and groundwater withdrawals causes increases and decreases in groundwater storage in different areas, which are summarized as outflows to and inflows from storage, respectively, in table 3. During 2013, the simulation showed a 27,000 acre-ft net increase in groundwater storage for the Quincy Subarea. 


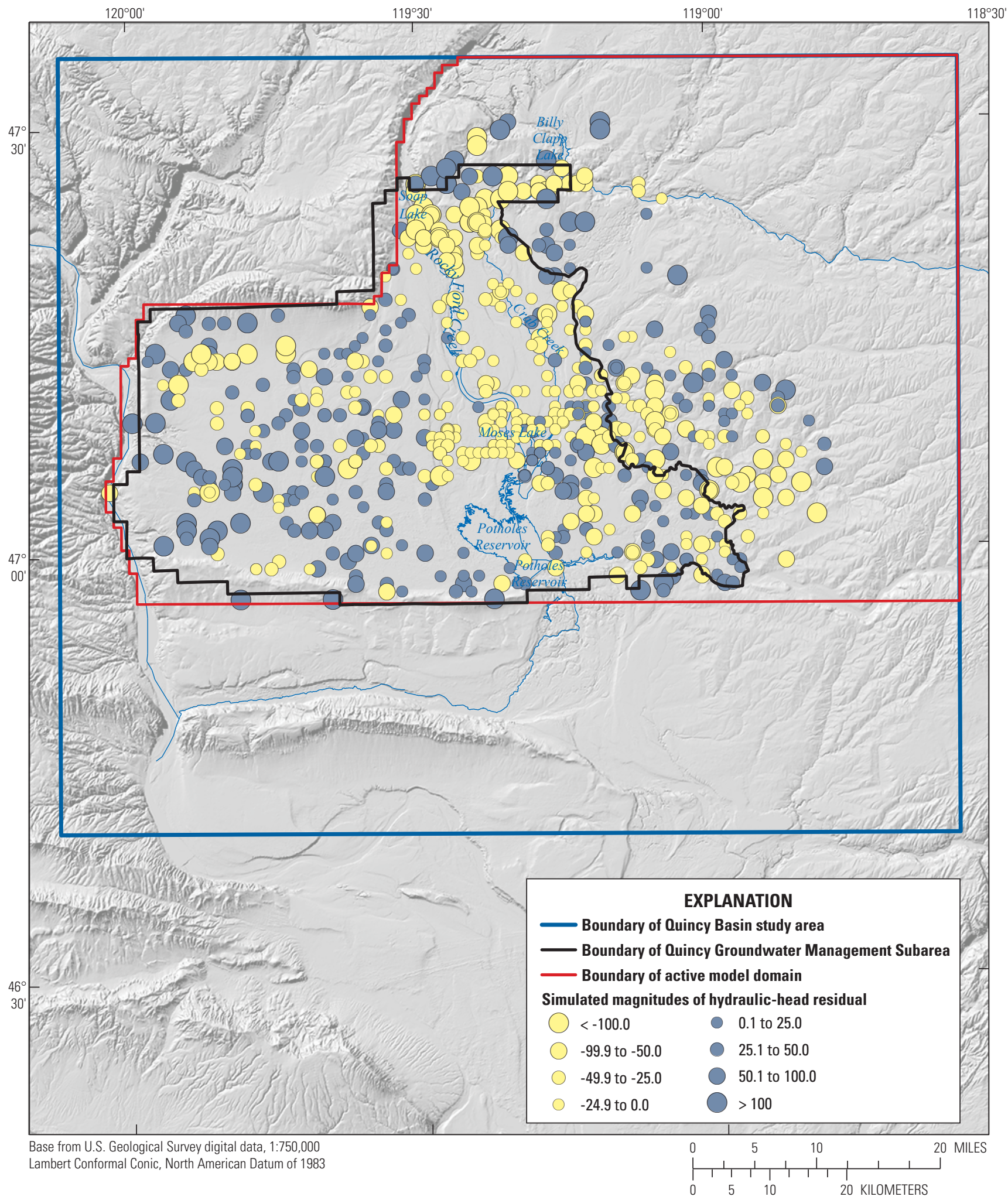

Figure 16. Simulated magnitudes of hydraulic-head residuals in the Quincy Basin, Washington. 


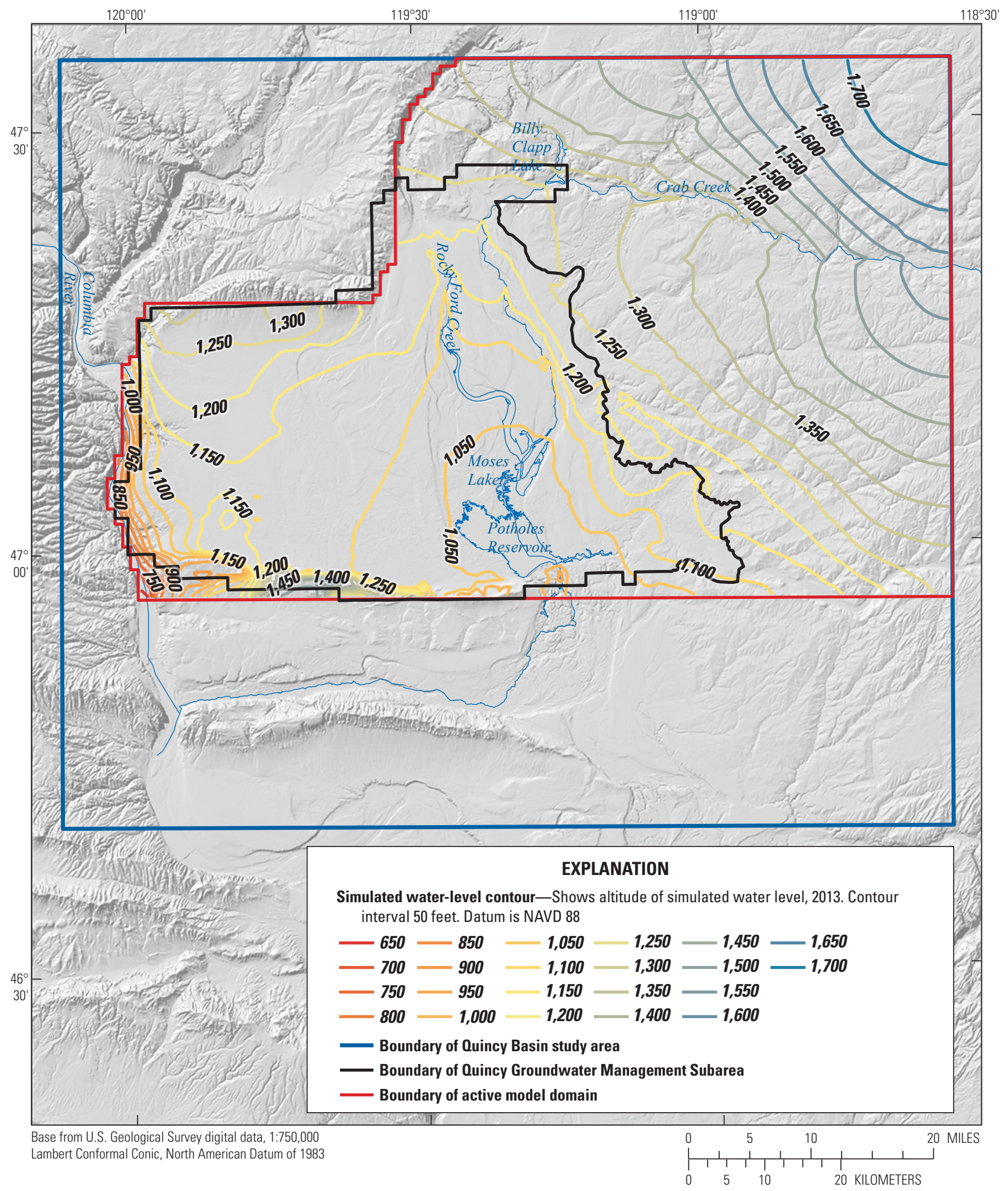

Figure 17. Contours of simulated water-level altitudes, Quincy Basin, Washington, 2013. 


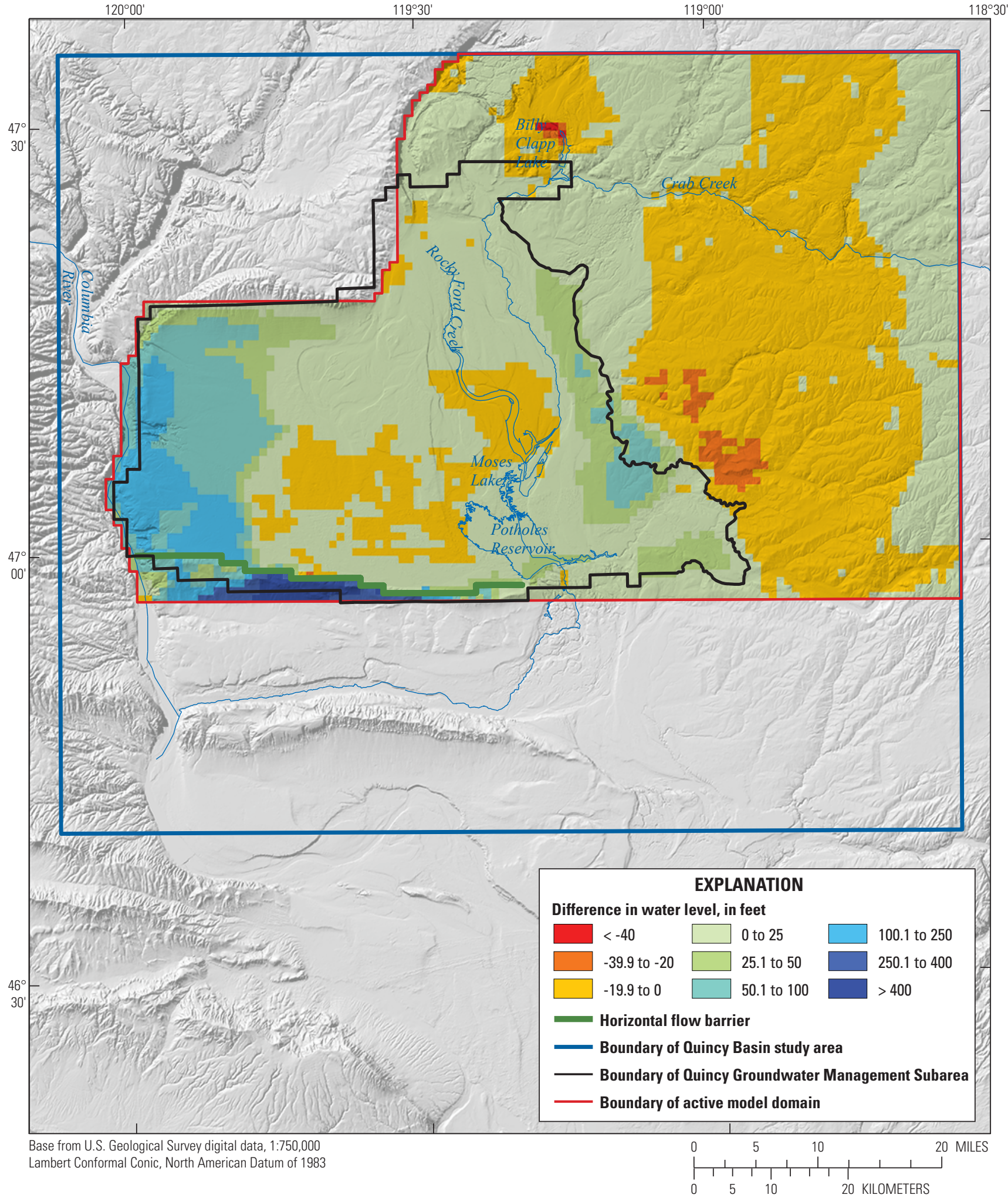

Figure 18. Simulated changes in water-level altitude, Quincy Basin, Washington, 1920-2013. 
Table 3. Groundwater budget of the Quincy Groundwater Management Subarea, Quincy Basin, Washington, pre-1920 and 2013.

[Values in thousands of acre-feet per year]

\begin{tabular}{|c|c|c|}
\hline & $\begin{array}{c}\text { Pre-1920 } \\
\text { (steady state) }\end{array}$ & 2013 \\
\hline \multicolumn{3}{|c|}{ Inflows } \\
\hline Recharge & 28 & 273 \\
\hline $\begin{array}{l}\text { Groundwater flow from } \\
\text { surrounding model domain }\end{array}$ & 37 & 27 \\
\hline $\begin{array}{l}\text { Lakes and groundwater flow } \\
\text { from model boundary }\end{array}$ & 27 & 25 \\
\hline Streams & 1 & 0 \\
\hline Reservoirs & 0 & 22 \\
\hline Storage & 0 & 38 \\
\hline Total & 93 & 385 \\
\hline \multicolumn{3}{|c|}{ Outflows } \\
\hline $\begin{array}{l}\text { Groundwater flow to } \\
\quad \text { surrounding model domain }\end{array}$ & 44 & 55 \\
\hline $\begin{array}{l}\text { Lakes and groundwater flow } \\
\text { from model boundary }\end{array}$ & 20 & 23 \\
\hline Streams & 28 & 35 \\
\hline Reservoirs & 0 & 1 \\
\hline Groundwater withdrawals & 0 & 200 \\
\hline Drains & 1 & 6 \\
\hline Storage & 0 & 65 \\
\hline Total & 93 & 385 \\
\hline
\end{tabular}

Water budgets for 2013 also were calculated for three other areas of interest within the Quincy Subarea: (1) High Hills Irrigation development area, (2) Moses Lake Irrigation Rehabilitation District, and (3) the City of Quincy (fig. 20 and table 4). In the High Hills area, inflows primarily are the result of groundwater flow from the surrounding area and recharge from the surface. Groundwater withdrawals of 974 acre- $\mathrm{ft}$ account for 22 percent of the total outflow, with the remainder flowing out to Soap Lake and the surrounding area. There was a net increase in the amount of water stored in the area of 59 acre-ft for 2013. In the Moses Lake area, inflows primarily are the result of groundwater flow from the surrounding area, recharge from the surface, and from storage. Groundwater withdrawals of 19,242 acre-ft account for almost 67 percent of the total outflow, with most of the rest of the groundwater flowing out to the surrounding area. In 2013, there was a net decrease of 4,614 acre- $\mathrm{ft}$ in the amount of water stored in the area. For the area around the City of Quincy, inflows primarily are the result of groundwater flow from the surrounding area and recharge from the surface, with a minor amount coming from storage. Groundwater withdrawals of 3,017 acre-ft account for 43 percent of the total outflow, with the remainder flowing out through the groundwater system to the surrounding area. In 2013. there was a net decrease of 85 acre-ft in the amount of water stored in the area.

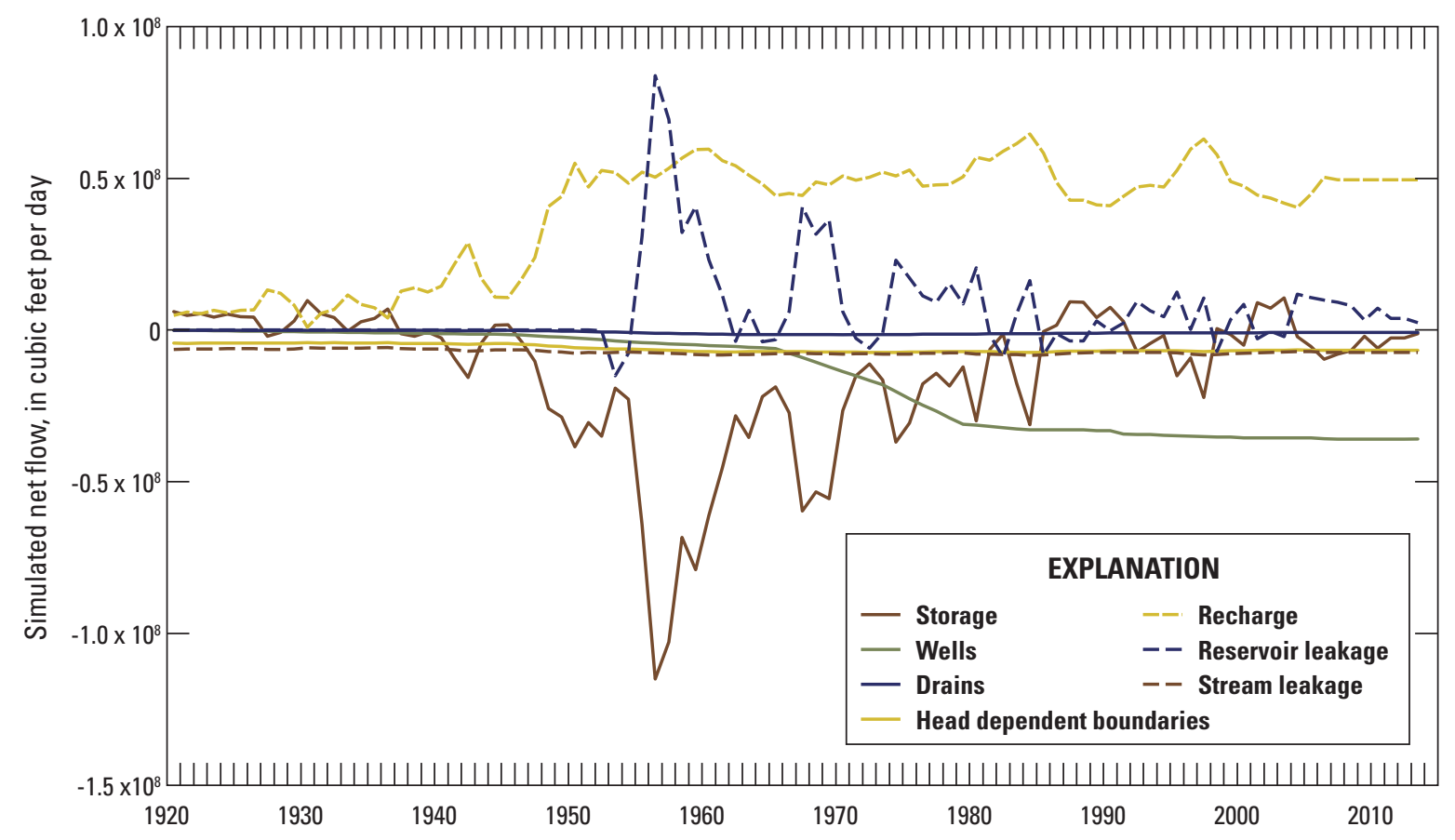

Figure 19. Simulated net flows into the groundwater model domain, Quincy Basin, Washington, 1920-2013. 


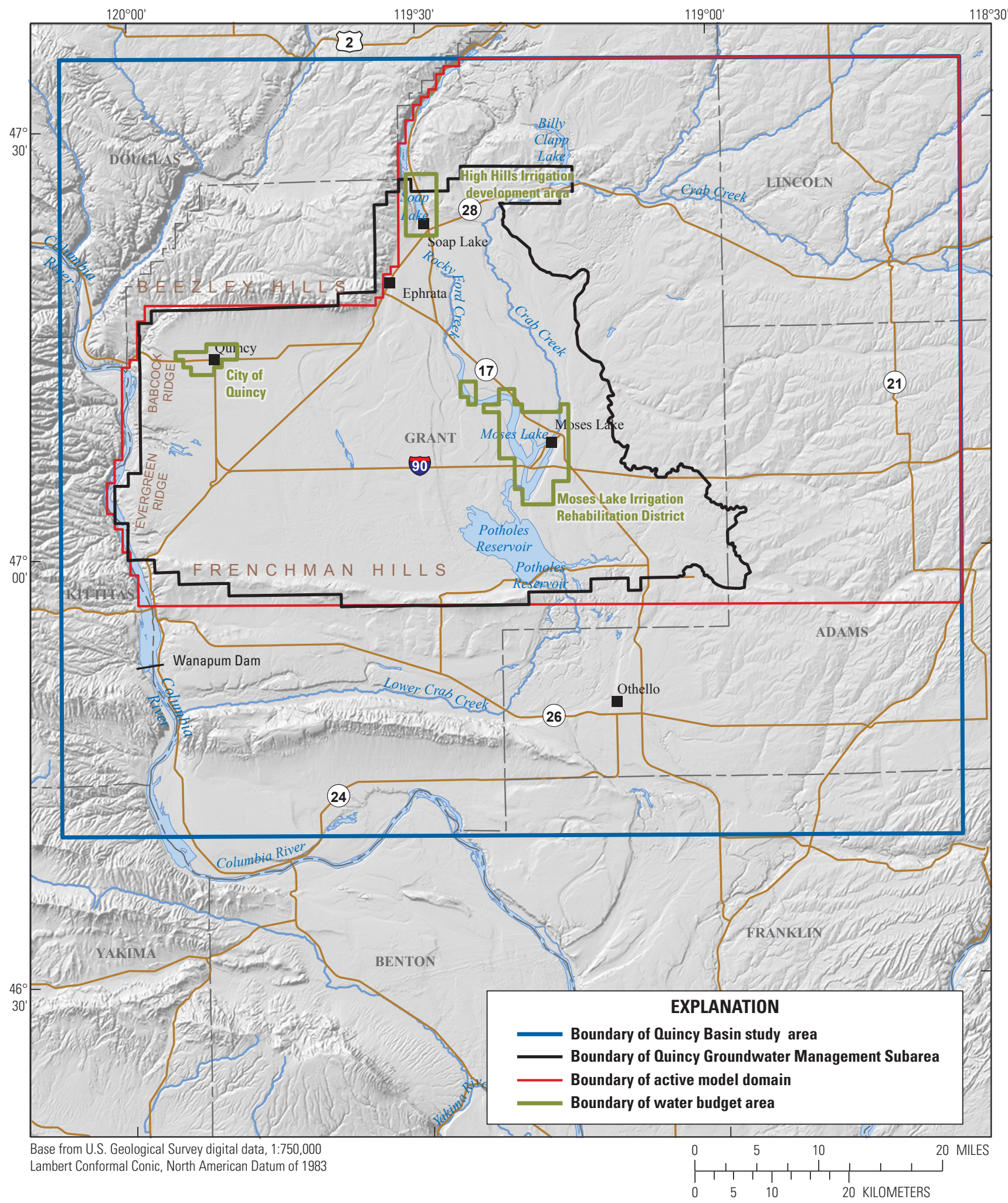

Figure 20. Water budget areas, Quincy Basin, Washington, 1920-2013. 
Table 4. Groundwater budget of the High Hills Irrigation development area, Moses Lake Irrigation Rehabilitation District, and the City of Quincy, Washington, 2013.

[Values in acre-feet per year]

\begin{tabular}{lcrr}
\hline & High Hills & Moses Lake & City of Quincy \\
\hline & Inflows & & \\
\hline Recharge & 980 & 8,467 & 2,231 \\
Groundwater flow from & 3,432 & 15,062 & 4,622 \\
$\quad$ surrounding model domain & & 3 & 0 \\
Lakes & 0 & 204 & 0 \\
Streams & 0 & 5,106 & 85 \\
Storage & 6 & 28,841 & 6,938 \\
$\quad$ Total & 4,417 & & \\
\hline & 0 utflows & 8,916 & 3,921 \\
Groundwater flow to & 3,367 & & 0 \\
$\quad$ surrounding model domain & 11 & 4 & 0 \\
Lakes & 0 & 186 & 0 \\
Streams & 974 & 492 & 6,017 \\
Groundwater withdrawals & 65 & 28,841 & \\
Storage & 4,417 & & \\
$\quad$ Total & & & \\
\hline
\end{tabular}

\section{Simulated Storage Changes in the Quincy Subarea}

The cumulative simulated change in storage through 2013 was summarized for the entire model domain as well as the Quincy Subarea within the model domain (fig. 1) for all model layers as well as just the unconsolidated layers (fig. 21) in which Ecology regulates groundwater withdrawals. Note that cumulative increases in groundwater storage are shown as a positive quantity in figure 21 (in contrast to the negative rates of flow from the groundwater system into storage shown in figure 19). To evaluate the effect of approving pending applications for groundwater-withdrawal permits, anthropogenic additions to storage (referred to as "artificiallystored" groundwater by Ecology) must be quantified. The changes to groundwater storage in the Quincy Subarea for all model layers, as well as just for the unconsolidated layers, are shown with the total for the model domain (fig. 21). The additional groundwater in storage since the predevelopment period in the Quincy Subarea rapidly reached about 10 million acre-ft by 1980 and has slowly increased since then to about 11.5 million acre-ft in 2013. The storage increase for just the unconsolidated units in the Quincy Subarea totaled about 9.5 million acre-ft by 2013. A small sliver of the Quincy
Subarea south of the Frenchman Hills Fault is isolated from the remainder of the Subarea and had an increase in storage of 0.31 million acre-ft by 2013 . Virtually all of the increase in storage for the model domain occurs in the Quincy Subarea.

A larger change in storage was noted in this study than in Tanaka and others (1974). Tanaka and others (1974) reported an increase in storage in their upper aquifer, which equates to the unconsolidated units, of 2.7 million acre- $\mathrm{ft}$ from 1952 to 1968, whereas this study simulated an increase of about 4.9 million acre-ft of increased storage for the same period.

\section{Limitations and Appropriate Use of the Model}

A groundwater-flow model represents a complex, natural system with a set of mathematical equations that describe the groundwater-flow system. Intrinsic to the model is the error and uncertainty associated with the approximations, assumptions, and simplifications that must be made. Hydrologic-modeling errors typically are the consequence of a combination of (1) input data, (2) representation of the physical processes by the algorithms of the model, and (3) parameter estimation during the calibration procedure (Troutman, 1985). Examples of the three types of model errors and how those errors limit application of the model follow. 


\section{Examples of Errors in Model Input Data}

Input data on types and thicknesses of hydrogeologic units, water levels, recharge and groundwater withdrawal amounts, and hydraulic properties represent only approximations of actual values. Parts of the model domain include areas that are poorly characterized. In areas without lithologic well logs, variability in hydrogeologic properties or depths of contacts may be outside the range of values in areas that have been better characterized, and the errors associated with this variability would remain unrepresented. Specific conclusions drawn from regions of the model with sparse observations should be limited to general flow directions and relative magnitudes.

The absence of historical withdrawal data from wells results in the greatest limitation of the groundwater model. Although the best available land- and water-use data were used, the method that specified the spatial distribution of withdrawals both by area and aquifer (that is, assigned model layer) is uncertain and introduces error in the simulated withdrawal wells because the actual historical withdrawals are unknown. The observed water levels used for model calibration respond to actual groundwater withdrawals, but because the location and magnitude of withdrawals specified in the model is at best an approximation of the actual withdrawals, water levels simulated at observation-well locations cannot reproduce measured water levels with high accuracy. Although the model may not simulate water levels measured at a particular location with high accuracy, average simulated changes in water levels, such as those resulting from increased recharge over many years, are more reliable. Changes in water levels resulting from an additional simulated stress also may be simulated more accurately than the altitudes of the water levels.

Recharge values for 2008-13 used the 2007 recharge rates, as no data for 2008 and later were available.

Because 2007 precipitation was similar to the mean annual precipitation (Kahle and others, 2011), extrapolation of the 2007 simulated recharge was considered a reasonable representation for subsequent years. However, this estimation could result in different results if actual values of recharge were known for that period.

The calibration bounds for hydraulic-property data generally came from specific-capacity tests, which typically measure drawdown at one time and at one pumping rate, and typically are not as accurate as aquifer tests. Thus, broad ranges of hydraulic-property parameter values are possible. Additionally, lack of information on streambed hydraulic conductivity values resulted in these values being poorly constrained, which limit the accuracy of groundwater/surfacewater exchanges.

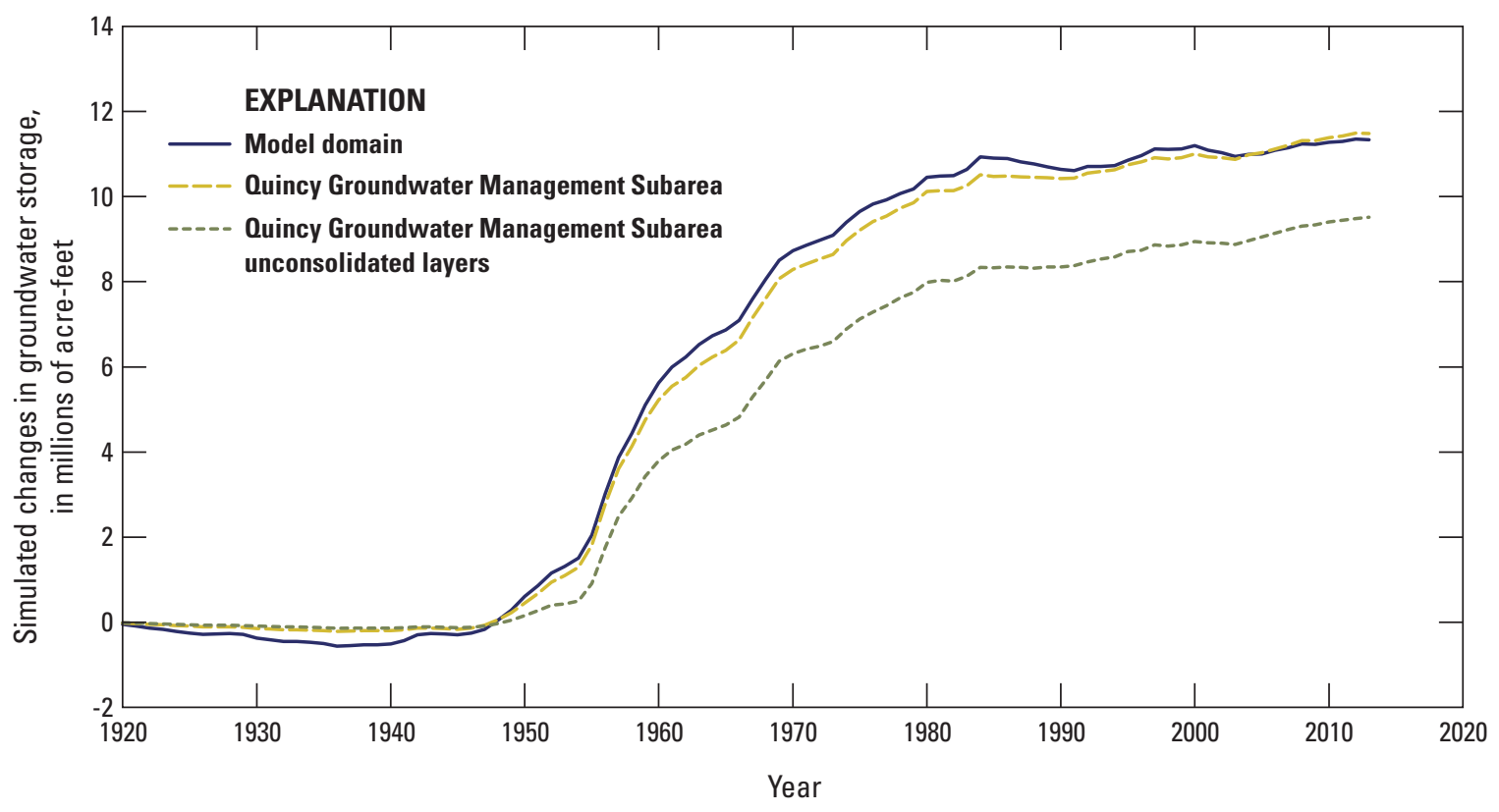

Figure 21. Cumulative simulated changes in groundwater storage in the model domain and areas in the Quincy Groundwater Management Subarea, Quincy Basin, Washington, 1920-2013. 


\section{Examples of Errors in Representation of the Physical Processes by the Algorithms of the Model}

All the physical processes within a watershed cannot be represented completely or "captured" in a numerical model. Determining if a weakness in a simulation is attributable to input data error or model shortcomings is almost impossible, but the simplifying assumptions and generalizations that are incorporated in a model undoubtedly affect the results of the simulation.

Model-discretization errors (including effects of averaging elevation information over the model cell size) result from inaccuracies in the geometric representation of hydrogeologic units, in the representation of the bedrock areas and their contact with unconsolidated units, and in the location of the Frenchman Hills Fault zone. For this reason, interpretations of simulation results should be limited to scales several times greater than the model spatial and temporal resolutions of $1 \mathrm{~km}$ and 1 year.

\section{Examples of Errors in Parameter Estimation During the Model Calibration Procedure}

Errors in parameter estimates occur when improper values are selected during the calibration process. Various combinations of parameter values may result in low residual error yet may improperly represent the actual system. An acceptable degree of agreement between simulated and measured values does not guarantee that the estimated modelparameter values uniquely and reasonably represent the actual parameter values. The use of automatic parameter estimation techniques and associated statistics, such as composite scaled sensitivities and correlation coefficients, removes some of the effects of non-uniqueness, but does not eliminate the problem entirely. The comparison of calibrated values to literature values also can reduce error caused by parameter estimation if the model simulation results are within previously accepted ranges. Limitations of the observation weighting scheme used in this study include non-varying weights for heads that did not account for measurement errors within each group of measurements.

\section{Appropriate Use of the Model}

If the regional groundwater-flow model is used appropriately, the effects of the simplifications and other potential errors can be limited. If the model is used for simulations beyond which it was designed, however, the generalizations and assumptions used could significantly affect the results. Because of the model scale and level of detail, the model generally is most applicable to analysis of regionalscale groundwater problems. Local-scale (anything less than an area $3 \times 3 \mathrm{~km}$ ) heterogeneity in hydrologic properties, recharge, and discharge is not represented adequately by the regional-scale, groundwater-flow model constructed for this study.

\section{Scenarios}

The groundwater-flow model was used to simulate possible effects on water levels caused by potential changes in recharge, well withdrawals, and streamflow. A simulation with the calibrated transient model with a final stress period of the model (representing year 2013) run to steady-state conditions was done to provide a "base simulation" for scenario comparison. Four scenarios were formulated and simulated using the steady-state 2013-simulation conditions to show how the model could be used to investigate water-resource issues. Results from the scenario model simulations were compared to base simulation results and resultant changes in water-level altitudes were evaluated. The change in storage over time was not evaluated as the scenarios are run to steady-state. Model scenarios were developed to evaluate the following conditions:

- Scenario 1. Reduce recharge in irrigated areas by 10 percent from 2013 amounts to assess the effects of increased irrigation efficiency.

- Scenario 2. Increase current withdrawals from 2013 amounts by 2,000 acre-ft/yr to access future increases in permitted withdrawals.

- Scenario 3. Increase streamflow in Crab Creek downstream of Billy Clapp Lake by $100 \mathrm{ft}^{3} / \mathrm{s}$ to assess the effect of routing additional flow down Crab Creek.

- Scenario 4. Increase streamflow in Crab Creek downstream of Billy Clapp Lake by $500 \mathrm{ft}^{3} / \mathrm{s}$ to assess the effect of routing additional flow down Crab Creek. 


\section{Scenario 1-Reduce Recharge}

Scenario 1 uses the conditions for the 2013 stress period run to steady-state with the exception of reducing recharge by 10 percent in all irrigated areas, which were determined as being those cells with recharge greater than the background rate of $2 \mathrm{in} / \mathrm{yr}$. The purpose of this scenario is to simulate the effects of increasing irrigation efficiency. All other boundary conditions were left unchanged.

Reducing recharge amounts by 10 percent in irrigated areas reduces water-level altitudes throughout the model domain compared to the conditions for the 2013 stress period run to steady-state (fig. 22). Most of the model domain shows simulated declines of about $0-15 \mathrm{ft}$, particularly in areas that did not have much irrigation. Areas of the model with higher irrigation amounts have larger declines, with areas east of Moses Lake having declines of as much as $50 \mathrm{ft}$ and areas west of Potholes Reservoir also having declines of as much as $50 \mathrm{ft}$ with isolated pockets exceeding $50 \mathrm{ft}$.

\section{Scenario 2-Increase Withdrawal Amounts}

Scenario 2 uses the conditions for the 2013 stress period run to steady-state, with the exception of increasing groundwater withdrawals in the Quincy Subarea. The total withdrawals in the Quincy Subarea were increased by about 2,000 acre-ft/yr to represent the additional permitting capacity available in the subarea. Because the location of future withdrawals is unknown, withdrawals for all wells that are screened in the unconsolidated sediments or the upper two basalt layers within the subarea were increased in proportion (about 1.2 percent) to their original withdrawal amount. Wells that were open to the Grande Ronde Basalt were not increased. All other boundary conditions were left unchanged.

Simulated increases in groundwater withdrawal rates result in decreased water-level elevations. Simulated water levels decline by as much as about $5 \mathrm{ft}$ compared to the conditions for the 2013 stress period run to steady-state (fig. 23). Groundwater levels decline by about $0-2 \mathrm{ft}$ in most of the model domain. The largest declines (from about 2 to more than $5 \mathrm{ft}$ ) occur to the west of Potholes Reservoir. Because the increased groundwater withdrawals are spread throughout the Quincy Subarea, actual changes in water levels are different depending on where the additional withdrawals actually occur.

\section{Scenario 3-Increase Flow in Crab Creek Downstream of Billy Clapp Lake by 100 Cubic Feet Per Second}

Reclamation is interested in establishing a supplemental route to route water into Potholes Reservoir from Billy Clapp Lake using the natural channel of Crab Creek. To simulate the effects of adding additional water in this steady-state simulation, $100 \mathrm{ft}^{3} / \mathrm{s}$ was added to the flow in Crab Creek where it passes Billy Clapp Lake and compared to the conditions for the 2013 stress period run to steady-state. No other boundary conditions were changed.

In this scenario, the simulated groundwater levels rise near Crab Creek between Billy Clapp Lake and Moses Lake as the stage of the creek rises with the additional flow (fig. 24). Groundwater levels generally rise by about $5-10 \mathrm{ft}$ alongside the creek, with a few areas rising by more than $10 \mathrm{ft}$. Farther away from the stream, groundwater levels rise by about $2.5-5$ $\mathrm{ft}$, with areas farthest from the stream having a minimal rise of about $0-2.5 \mathrm{ft}$.

\section{Scenario 4-Increase Flow in Crab Creek Downstream of Billy Clapp Lake By 500 Cubic Feet Per Second}

Scenario 4 is identical to scenario 3, with the exception of $500 \mathrm{ft}^{3} / \mathrm{s}$ of additional water being added to Crab Creek downstream of Billy Clapp Lake rather than $100 \mathrm{ft}^{3} / \mathrm{s}$. No other boundary conditions were changed.

With the addition of $500 \mathrm{ft}^{3} / \mathrm{s}$ to Crab Creek, the simulated groundwater levels rise near Crab Creek between Billy Clapp Lake and Moses Lake as the stage of the creek rises with the additional flow (fig. 25). The groundwater levels rise higher and over a larger area than with the addition of $100 \mathrm{ft}^{3} / \mathrm{s}$. Groundwater levels generally rise by about $20-30 \mathrm{ft}$ alongside the creek, with a few areas rising by more than 30 $\mathrm{ft}$. Farther away from the stream, the effect of the additional water in the stream diminishes as groundwater levels rise by about $2.5-20 \mathrm{ft}$, with areas farthest from the stream having a minimal rise of about $0-2.5 \mathrm{ft}$. 


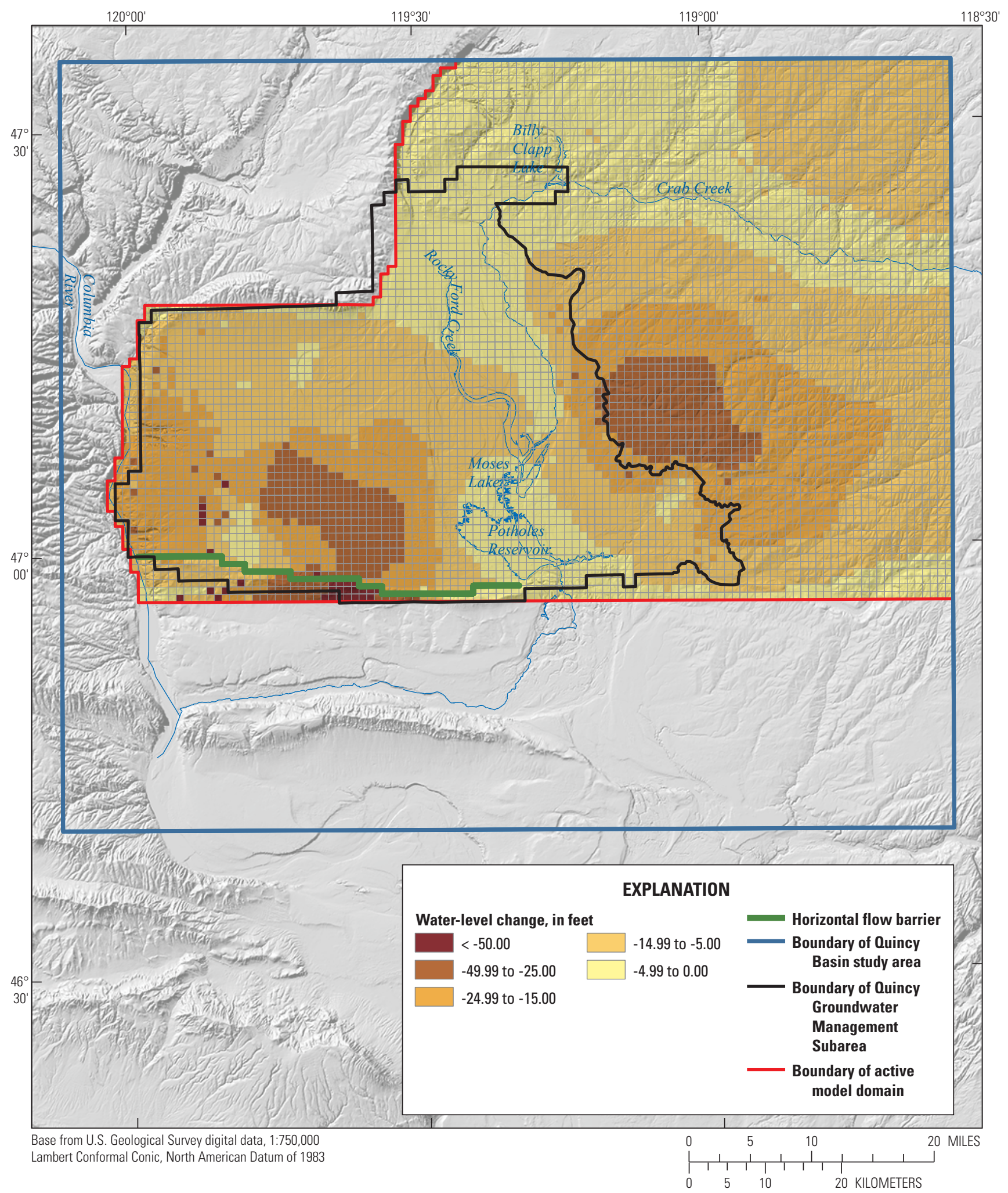

Figure 22. Simulated water-level changes after reducing 2013 irrigation amounts by 10 percent, Quincy Basin, Washington. 


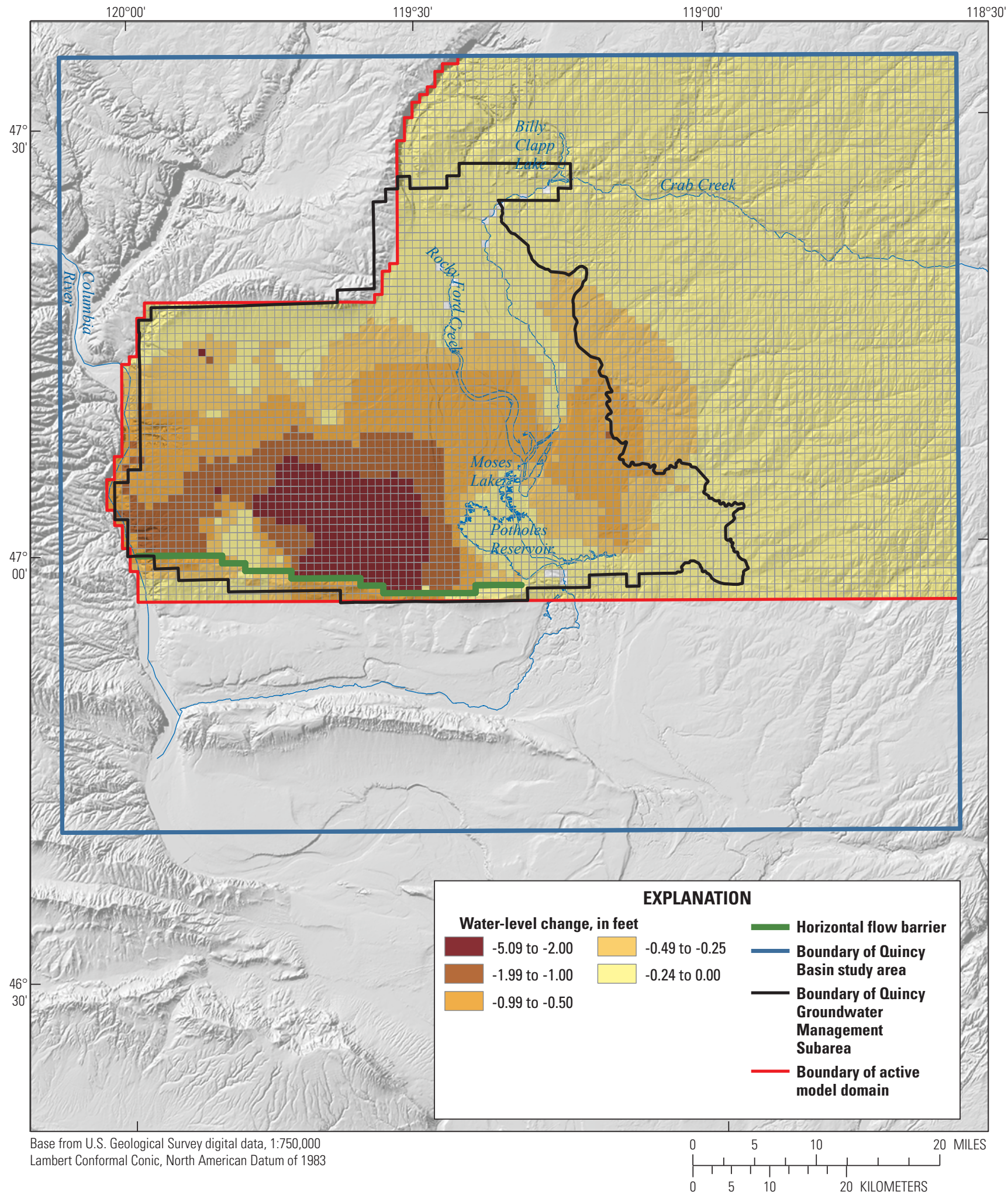

Figure 23. Simulated water-level changes after increasing groundwater withdrawal amounts by 2,000 acre-feet per year, Quincy Basin, Washington. 


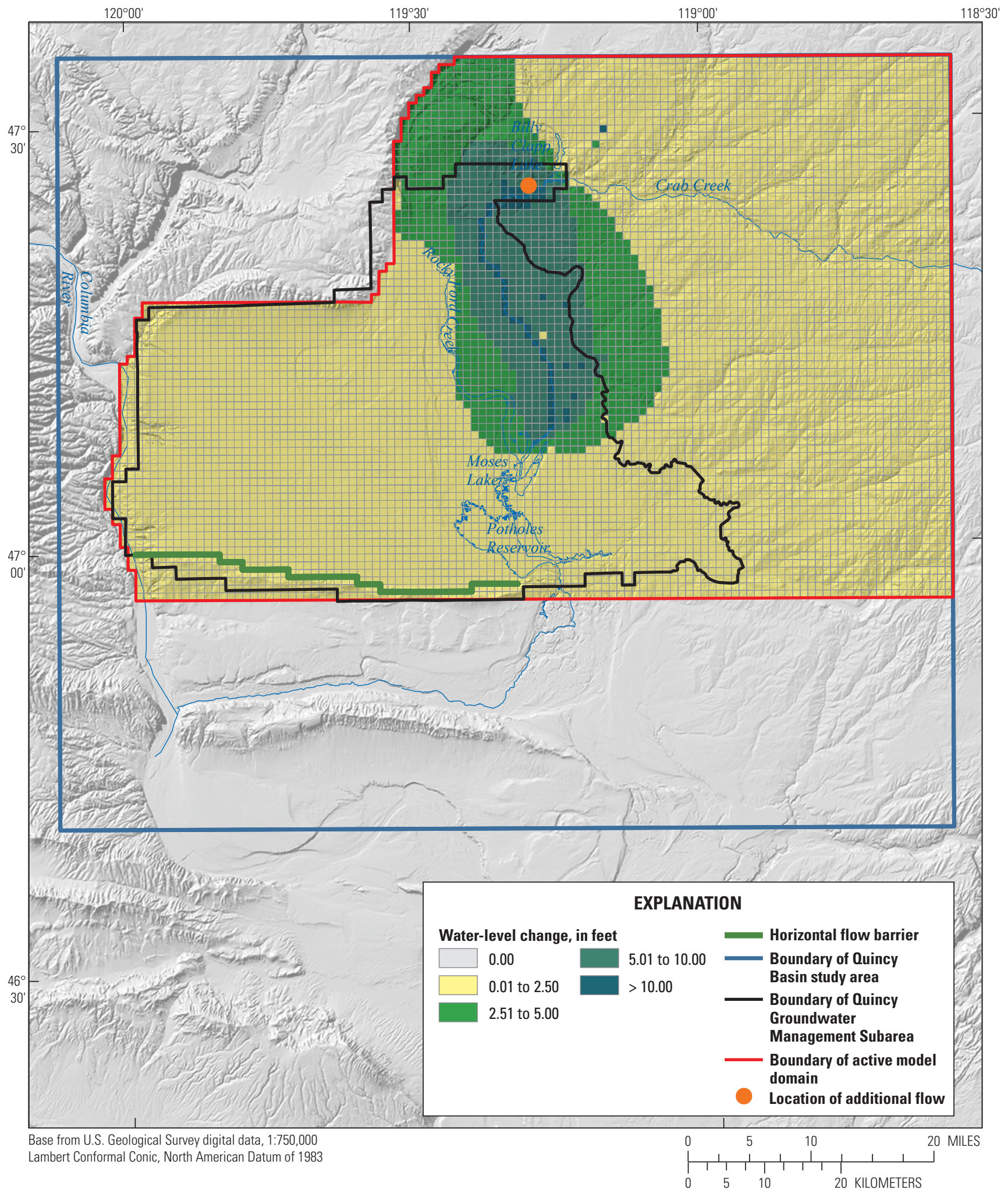

Figure 24. Simulated water-level changes after increasing flow in Crab Creek downstream of Billy Clapp Lake by 100 cubic feet per second, Quincy Basin, Washington. 


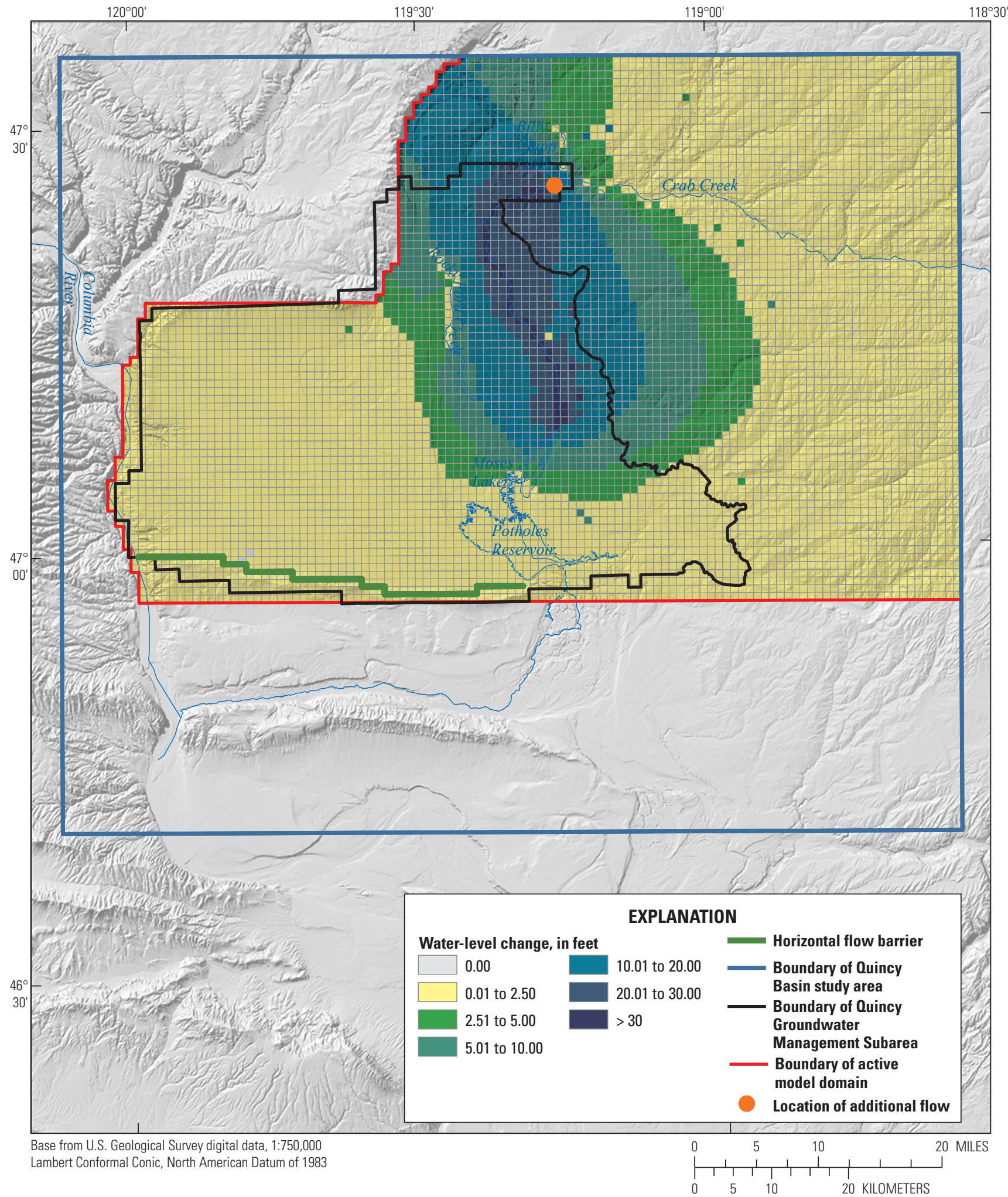

Figure 25. Simulated water-level changes after increasing flow in Crab Creek downstream of Billy Clapp Lake by 500 cubic feet per second, Quincy Basin, Washington. 


\section{Summary}

The Miocene Columbia River Basalt Group and younger sedimentary deposits of lacustrine, fluvial, eolian, and cataclysmic-flood origin compose the aquifer system of the Quincy Basin in eastern Washington. Irrigation return flow and canal leakage from the Columbia Basin Project have recharged this aquifer system under parts of the Quincy Basin since 1952. Groundwater levels in the sedimentary overburden have risen substantially in some areas of the Quincy Basin. State and local water resource managers are considering extracting the additional stored groundwater to supply increasing demand. The objectives of this study were to (1) define the area hydrogeology, (2) determine rates and directions of groundwater flow through the aquifer system, (3) quantify the effect of anthropogenic recharge and groundwater withdrawals on groundwater storage, and (4) simulate the effects of certain groundwater-management scenarios.

To address the objectives of this study, the U.S. Geological Survey developed a transient groundwater model of the Quincy Basin that quantifies changes in groundwater flow and storage. The model uses a 1-kilometer finite difference grid with MODFLOW-NWT (the Newton Solver package in the U.S. Geological Survey modular threedimensional finite-difference groundwater-flow model) and is constrained by 698 well logs in the study area. Five model layers represent two sedimentary hydrogeologic units and the underlying basalt formations. Head-dependent flux boundaries represent the Columbia River and other streams, lakes and reservoirs, underflow to and (or) from adjacent areas, and discharge to agricultural drains and springs. Specified flux boundaries represent recharge from precipitation and anthropogenic sources, including irrigation flows and leakage from water-distribution canals and discharge through groundwater withdrawal wells. The model was calibrated with the parameter-estimation code PEST to a total of 4,064 water levels measured in 710 wells.

A simulated increase of about 11.5 million acrefeet in groundwater storage in the Quincy Subarea since predevelopment results from Columbia Basin Irrigation Project operations increasing the recharge into the aquifer system. Four hypothetical groundwater-management scenarios were simulated to estimate potential changes in groundwater levels due to changed conditions. Scenario 1 simulates a reduction in recharge of 10 percent in all irrigated areas to simulate increase irrigation efficiency. Most of the model domain would have groundwater-level declines of about $0-15$ feet, with areas east of Moses Lake and west of Potholes Reservoir having declines of as much as 50 feet. Scenario 2 simulates an increase in groundwater withdrawal amounts by 2,000 acre-feet per year in the Quincy Subarea. Increasing groundwater withdrawals decreases groundwater levels by as much as about 5 feet. Groundwater levels would decline in most of the model domain by only about $0-2$ feet. The largest declines occur west of Potholes Reservoir. Scenarios 3 and 4 simulate an increase in flow in Crab Creek downstream of Billy Clapp Lake of 100 and 500 cubic feet per second $\left(\mathrm{ft}^{3} / \mathrm{s}\right)$, respectively. Groundwater levels increase over 2013 steady-state levels with the increased streamflow. Areas closer to the stream rise more than those areas farther away, with groundwater levels rising by about 5-10 feet along the stream with the addition of $100 \mathrm{ft}^{3} / \mathrm{s}$ of streamflow and by about 20-30 feet along the stream with the addition of 500 $\mathrm{ft}^{3} / \mathrm{s}$ of streamflow. Groundwater levels increase more and over a larger area with the addition of $500 \mathrm{ft}^{3} / \mathrm{s}$ of streamflow compared to the addition of $100 \mathrm{ft}^{3} / \mathrm{s}$ of streamflow.

\section{Acknowledgments}

The authors would like to thank the many people who have contributed to our understanding of the hydrogeology of the Quincy Basin, and the personnel of the Bureau of Reclamation and Washington State Department of Ecology involved in the Quincy Groundwater Management Area Program.

\section{References Cited}

Anderson, M.R., and Woessner, W.W., 1992, Applied groundwater modeling simulation of flow and advective transport: San Diego, New York, Boston, London, Sydney, Tokyo, Toronto, Academic Press, Inc., 381 p.

Bauer, H.H., and Vaccaro, J.J., 1990, Estimates of groundwater recharge to the Columbia Plateau Regional Aquifer System, Washington, Oregon, and Idaho, for predevelopment and current land-use conditions: U.S. Geological Survey Water-Resources Investigations Report 88-4108, 37 p., 2 pls.

Burns, E.R., Morgan, D.S., Peavler, R.S., and Kahle, S.C., 2011, Three-dimensional model of the geologic framework for the Columbia Plateau Regional Aquifer System, Idaho, Oregon, and Washington: U.S. Geological Survey Scientific Investigations Report 2010-5246, 44 p.

Burns, E.R., Snyder, D.T., Haynes, J.V., and Waibel, M.S., 2012, Groundwater status and trends for the Columbia Plateau Regional Aquifer System, Washington, Oregon, and Idaho: U.S. Geological Survey Scientific Investigations Report 2012-5261, $52 \mathrm{p}$.

Carnahan, B., Luther, H.A., and Wilkes, J.O., 1969, Applied numerical methods: New York, John Wiley and Sons, Inc., $604 \mathrm{p}$. 
de Marsily, G., Lavedan, G., Boucher, M., and Fasanino, G., 1984, Interpretation of interference tests in a well field using geostatistical techniques to fit the permeability distribution in a reservoir model, in Verly, G., David, M., Journel, A.G., and Marechal, A., eds., Geostatistics for natural resources characterization, Part 2: Dordrecht, The Netherlands, D. Reidel Publishing Company, p. 831-849.

Doherty, J., 2003, Ground water model calibration using pilot points and regularization: Ground Water, v. 41, no. 2, p. $170-177$.

Doherty, J., 2005, PEST-Model-independent parameter estimation: Corinda, Australia, Watermark Numerical Computing [variously paged].

Doherty, J., 2006, Addendum to PEST manual: Corinda, Australia, Watermark Numerical Computing [variously paged].

Doherty, J., Fienen, M.N., and Hunt, R.J., 2010, Approaches to highly parameterized inversion-Pilot-point theory guidelines, and research directions: U.S. Geological Survey Scientific Investigations Report 2010-5168, 36 p. [Also available at https://pubs.usgs.gov/sir/2010/5168/.]

Doherty, J.E., and Hunt, R.J., 2010, Approaches to highly parameterized inversion-A guide to using PEST for groundwater-model calibration: U.S. Geological Survey Scientific Investigations Report 2010-5169, 59 p. [Also available at https://pubs.usgs.gov/sir/2010/5169/.]

Drost, B.W., Ebbert, J.C., and Cox, S.E., 1993, Long-term effects of irrigation with imported water on water levels and water quality: U.S. Geological Survey Water-Resources Investigations Report 93-4060, 19 p.

Drost, B.W., Ely, D.M., and Lum, W.E., 1999, Conceptual model and numerical simulation of the ground-water flow system in the unconsolidated sediments of Thurston County, Washington: U.S. Geological Survey Water-Resources Investigations Report 99-4165, 106 p. [Also available at https://pubs.usgs.gov/wri/wri994165/.]

Drost, B.W., and Whiteman, K.J., 1986, Surficial geology, structure, and thickness of selected geohydrologic units in the Columbia Plateau, Washington: U.S. Geological Survey Water-Resources Investigations Report 84-4326, 12 sheets.

Drost, B.W., Whiteman, K.J., and Gonthier, J.B., 1990, Geologic framework of the Columbia Plateau Aquifer System, Washington, Oregon, and Idaho: U.S. Geological Survey Water-Resources Investigations Report 87-4238, 13 p. 10 sheets.,
Ely, D.M., Burns, E.R., Morgan, D.S., and Vaccaro, J.J., 2014, Numerical simulation of groundwater flow in the Columbia Plateau Regional Aquifer System, Idaho, Oregon, and Washington (version 1.1, January 2015): U.S. Geological Survey Scientific Investigations Report 2014-5127, 90 p., https://dx.doi.org/10.3133/sir20145127.

Ely, D.M., and Kahle, S.C., 2012, Simulation of groundwater and surface-water resources and evaluation of water management alternatives for the Chamokane Creek Basin, Stevens County, Washington: U.S. Geological Survey Scientific Investigations Report 2012-5224, 74 p.

Fenske, J.P., Leake, S.A., and Prudic, D.E., 1996, Documentation of a computer program (RES1) to simulate leakage from reservoirs using the modular finite-difference ground-water flow model (MODFLOW): U.S. Geological Survey Open-File Report 96-364, 51 p.

Ferris, J.G., Knowles, D.B., Brown, R.H., and Stallman, R.W., 1962, Theory of aquifer tests: U.S. Geological Survey Water-Supply Paper 1536-E, 174 p.

Fienen, M.N., Muffels, C.J., and Hunt, R.J., 2009, Methods note- On constraining pilot point calibration with regularization in PEST: Ground Water, v. 47, no. 6, p. $835-844$.

Freeze, R.A., and Cherry, J.A., 1979, Groundwater: Englewood Cliffs, New Jersey, Prentice-Hall, 604 p.

Fry, J., Xian, G., Jin, S., Dewitz, J., Homer, C., Yang, L., Barnes, C., Herold, N., and Wickham, J., 2011, Completion of the 2006 national land cover database for the conterminous United States: Photogrammetric Engineering and Remote Sensing, v. 77, no. 9, p. 858-864.

Heywood, C.E., Kahle, S.C., Olsen, T.D., Patterson, J.D., and Burns, E., 2016, Simulation of groundwater storage changes in the eastern Pasco Basin, Washington: U.S. Geological Survey Scientific Investigations Report 2016-5026, 44 p., 1 pl., https://dx.doi.org/10.3133/sir20165026.

Hsieh, P.A., and Freckleton, J.R., 1993, Documentation of a computer program to simulate horizontal-flow barriers using the U.S. Geological Survey modular three-dimensional finite-difference ground-water flow model: U.S. Geological Survey Open-File Report 92-477, 32 p.

Hutchinson, M.F., 1989, A new method for gridding elevation and streamlining data with automated removal of pits: Journal of Hydrology, v. 106, p. 211-232. 
Kahle, S.C., Morgan, D.S., Welch, W.B., Ely, D.M., Hinkle, S.R., Vaccaro, J.J., and Orzol, L.L., 2011, Hydrogeologic framework and hydrologic budget components of the Columbia Plateau Regional Aquifer System, Washington, Oregon, and Idaho: U.S. Geological Survey Scientific Investigations Report 2011-5124, 66 p., https://pubs.usgs. gov/sir/2011/5124/pdf/sir20115124.pdf.

LaVenue, A.M., and Pickens, J.F., 1992, Application of a coupled adjoint sensitivity and kriging approach to calibrate a groundwater flow model: Water Resources Research, v. 28 , no. 6 , p. $1543-1569$.

Lidke, D.J., compiler, 2003, Fault number 561a, Frenchman Hills structures, Frenchman Hills fault, in Quaternary fault and fold database of the United States: U.S. Geological Survey web page, accessed February 6, 2018, at https:// earthquakes.usgs.gov/hazards/qfaults.

Lindsey, K., Tolan, T., Nielson, M., and Loper, S., 2007, Geologic framework of the suprabasalt sediment aquifer system, Columbia Basin Ground Water Management area of Adams, Franklin, Grant, and Lincoln Counties, Washington (edition 1): Prepared for Columbia Basin Ground Water Management Area by GSI Water Solutions, Inc. [variously paged].

McDonald, M.G., and Harbaugh, A.W., 1988, A modular three-dimensional finite-difference ground-water flow model: U.S. Geological Survey Techniques of WaterResources Investigations, book 6, chap. A1, 586 p.

Mundorff, M.J., Reis, D.J., and Strand, J.R., 1952, Progress report on ground water in the Columbia Basin Project, Washington: U.S. Geological Survey Open-File Report, $229 \mathrm{p}$.

Niswonger, R.G., Panday, S., and Ibaraki, M., 2011, MODFLOW-NWT, A Newton formulation for MODFLOW-2005: U.S. Geological Survey Techniques and Methods, book 6, chap. A37, 44 p. [Also available at https:// pubs.usgs.gov/tm/tm6a37/.]

Niswonger, R.G., and Prudic, D.E., 2005, Documentation of the Streamflow-Routing (SFR2) Package to include unsaturated flow beneath streams-A modification to SFR1: U.S. Geological Survey Techniques and Methods, book 6, chap. A13, 50 p. [Also available at https://pubs.usgs.gov/ $\mathrm{tm} / 2006 / \mathrm{tm} 6 \mathrm{~A} 13 /$.

Petkewich, M.D., and Campbell, B.G., 2007, Hydrogeology and simulation of ground-water flow near Mount Pleasant, South Carolina_Predevelopment, 2004, and predicted scenarios for 2030: U.S. Geological Survey Scientific Investigations Report 2007-5126, 79 p. [Also available at https://pubs.usgs.gov/sir/2007/5126/.]
Porcello, J., Kindsey, K., Tonkin, M., Muffels, C., and Karanovic, M., 2010, Groundwater model development process for the Columbia Basin Ground Water Management Area of Adams, Franklin, Grant, and Lincoln Counties, Washington: Prepared by the Columbia Basin Ground Water Management Area of Adams, Franklin, Grant and Lincoln Counties [variously paged].

Schwennesen, A.T., and Meinzer, O.E., 1918, Ground water in Quincy Valley, Washington: U.S. Geological Survey WaterSupply Paper 425-E, p. 131-161.

Snyder, D.T., and Haynes, J.V., 2010, Groundwater conditions during 2009 and changes in groundwater levels from 1984 to 2009, Columbia Plateau Regional Aquifer System, Washington, Oregon, and Idaho: U.S. Geological Survey Scientific Investigations Report 2010-5040, 12 p., https:// pubs.usgs.gov/sir/2010/5040/pdf/sir20105040.pdf.

Tanaka, H.H., Hansen, A.J., Jr., and Skrivan, J.A., 1974, Digital-model study of ground-water hydrology, Columbia Basin Irrigation Project area, Washington: Washington State Department of Ecology Water-Supply Bulletin No. 40, 60 p.

Taylor, G.D., Jr., 1948, Ground water in the Quincy Basin, Wahluke Slope, and Pasco Slope subareas of the Columbia Basin Project, Washington: U.S. Geological Survey OpenFile Report, $182 \mathrm{p}$.

Troutman, B.M., 1985, Errors and parameter estimation in precipitation-runoff modeling 2-Case study: Water Resources Research, v. 21, no. 8, p. 1214-1222.

U.S. Geological Survey, 2014, Hydrography-National hydrography dataset, watershed boundary dataset: U.S. Geological Survey web page, accessed 2014, at https://nhd. usgs.gov/index.html.

U.S. Geological Survey, 2017, 1 Arc-second Digital Elevation Models (DEMs) - USGS National Map 3DEP downloadable data collection: U.S. Geological Survey, https://viewer.nationalmap.gov/basic/.

U.S. Geological Survey, 2018, MODFLOW and related programs: U.S. Geological Survey web page, https://water. usgs.gov/ogw/modflow/.

Vaccaro, J.J., Kahle, S.C., Ely, D.M., Burns, E.R., Snyder, D.T., Haynes, J.V., Olsen, T.D., Welch, W.B., and Morgan, D.S., 2015, Groundwater availability of the Columbia Plateau Regional Aquifer System, Washington, Oregon, and Idaho: U.S. Geological Survey Professional Paper 1817, 87 p., https://dx.doi.org/10.3133/pp1817. 
Walters, K.L., and Grolier, M.J., 1960, Geology and groundwater resources of the Columbia Basin Project area, Washington: Washington Division of Water Resources Water-Supply Bulletin No. 8, 836 p.

Washington Division of Geology and Earth Resources, 2005, Digital 1:100,000-scale geology of Washington State, version 1.0: Washington Division of Geology and Earth Resources Open-File Report 2005-3.

Washington State Department of Ecology, 2016, Well reports: Washington State Department of Ecology web page, accessed July 2016, at https://fortress.wa.gov/ecy/ waterresources/map/WCLSWebMap/default.aspx.

Washington State Legislature, 1988, Quincy groundwater management subarea and zones: Washington Administrative Code, title 173, chapter 173-124, accessed June 21, 2018, at http://apps.leg.wa.gov/WAC/default.aspx?cite=173-124.
Washington State Legislature, 2003, Withdrawal of groundwaters-Permit required-Certain conditions and areas declared appropriate: Washington Administrative Code, title 508, chapter 508-14, section 508-14-30, accessed June 21, 2018, at http://apps.leg.wa.gov/WAC/default. aspx?cite $=508-14-030$.

Washington State Office of Financial Management, 2017, Census geographic files - Census 2010 data: Office of Financial Management database, accessed December 2017, at https:/www.ofm.wa.gov/washington-data-research/ population-demographics/gis-data/census-geographic-files.

Whiteman, K.J., Vaccaro, J.J., Gonthier, J.B., and Bauer, H.H., 1994, The hydrogeologic framework and geochemistry of the Columbia Plateau Aquifer System, Washington, Oregon, and Idaho: U.S. Geological Survey Professional Paper 1413-B, 73 p., accessed February 11, 2008, at http://pubs. usgs.gov/pp1413B/report.pdf. 


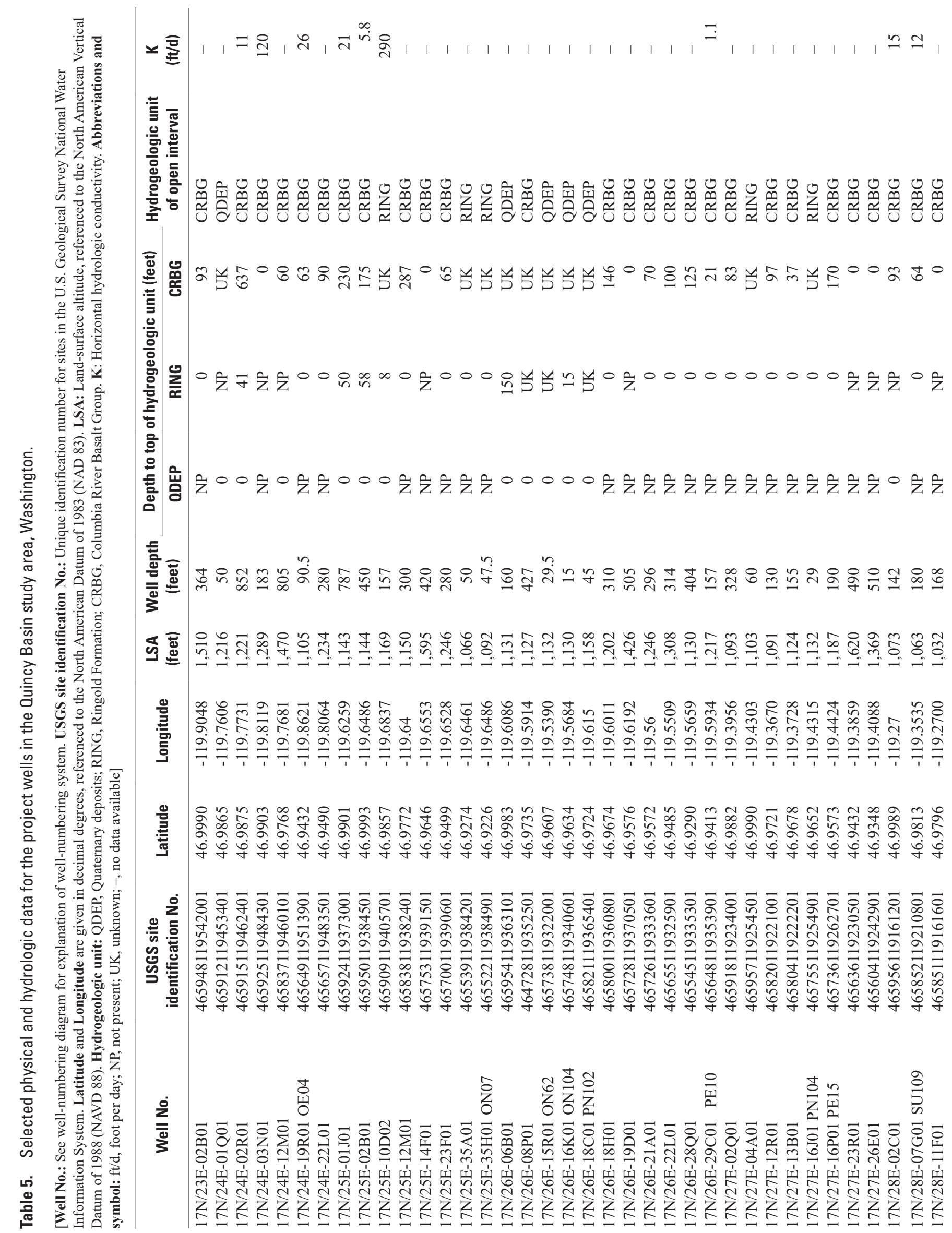




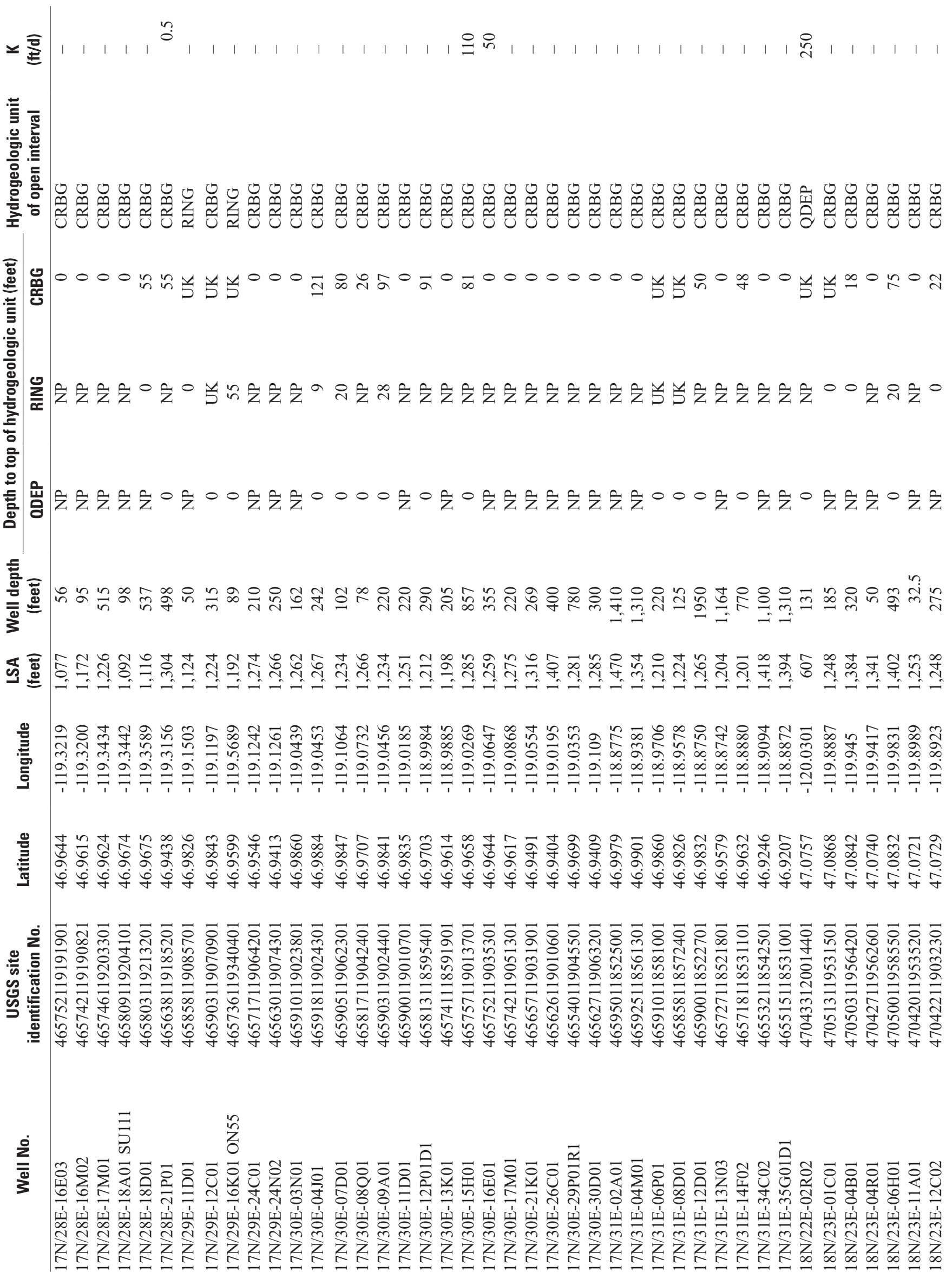




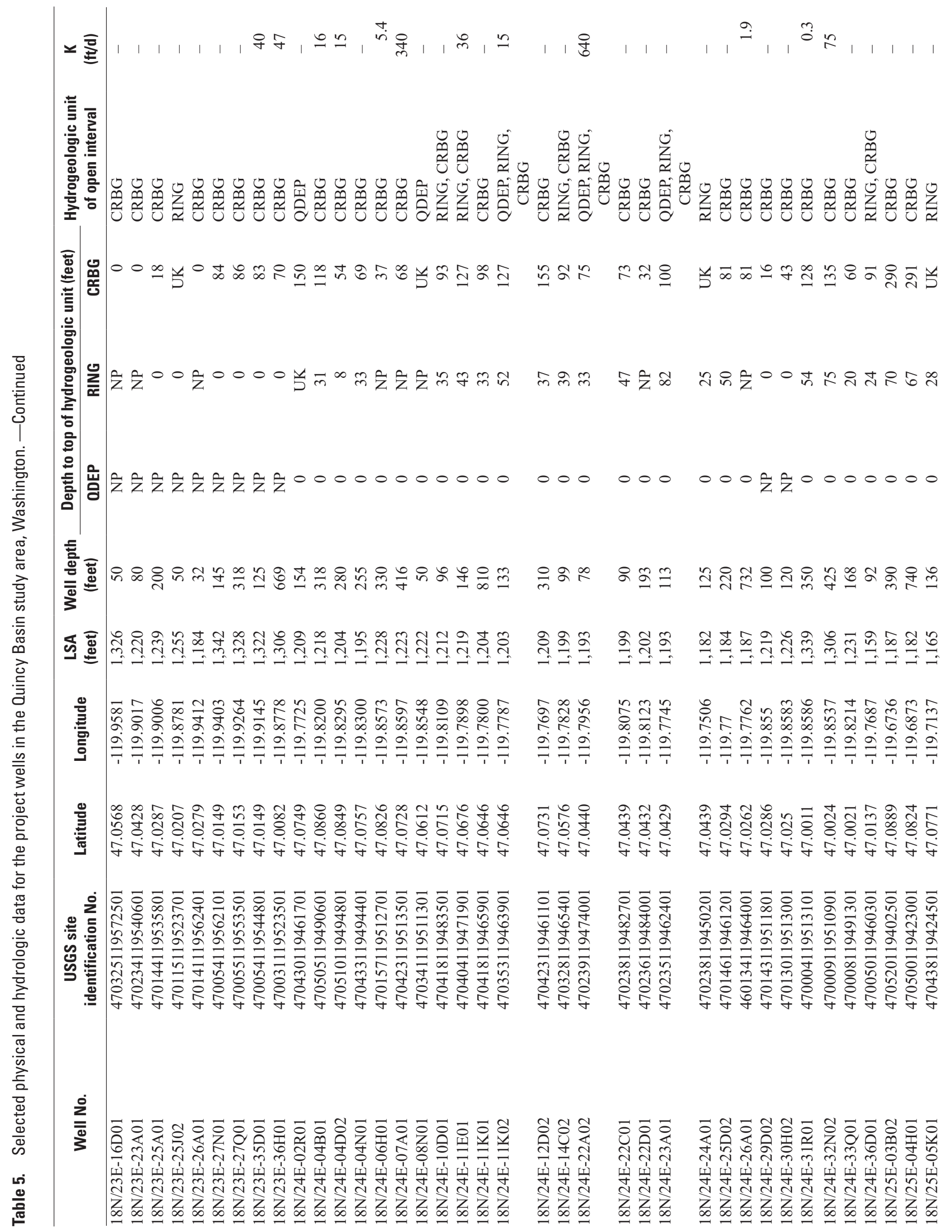




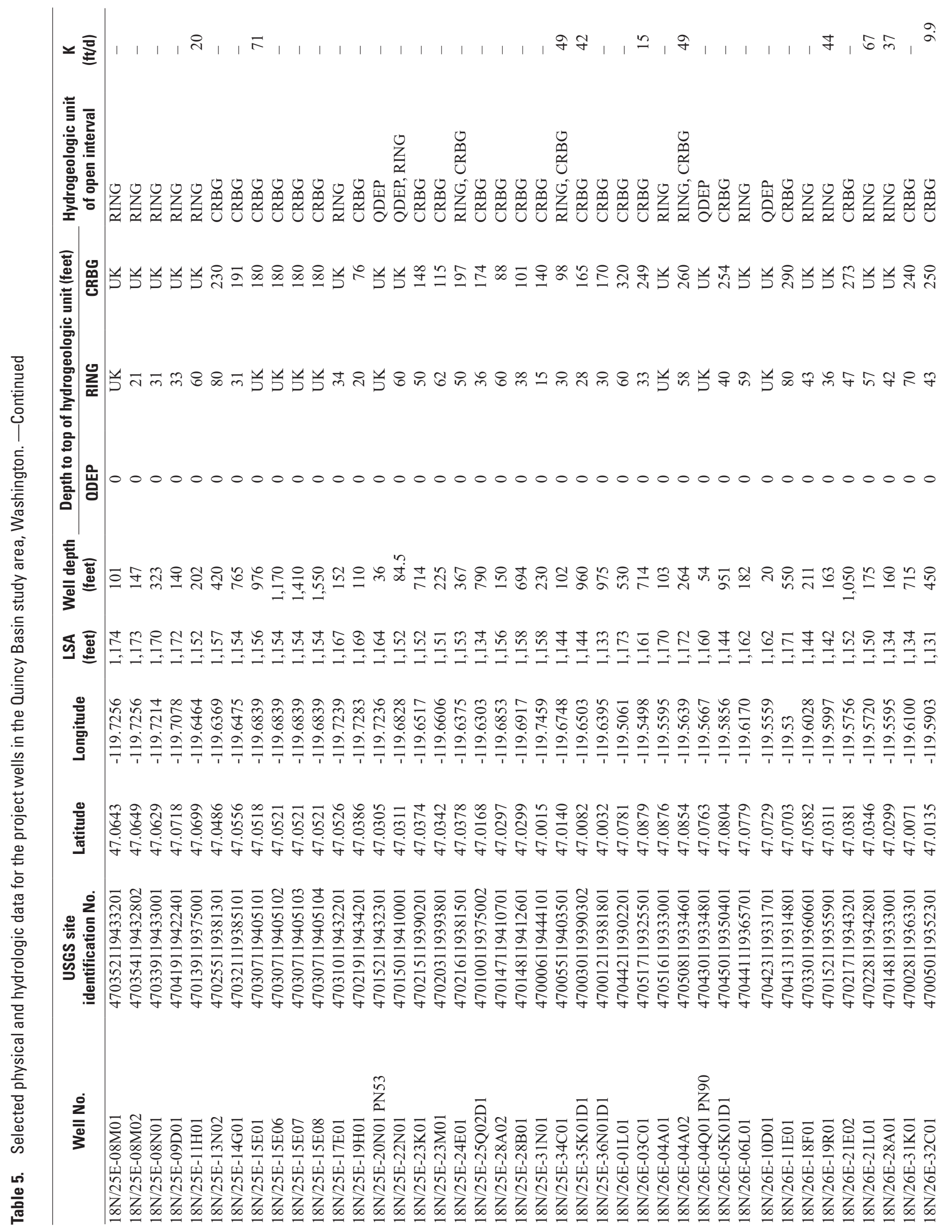




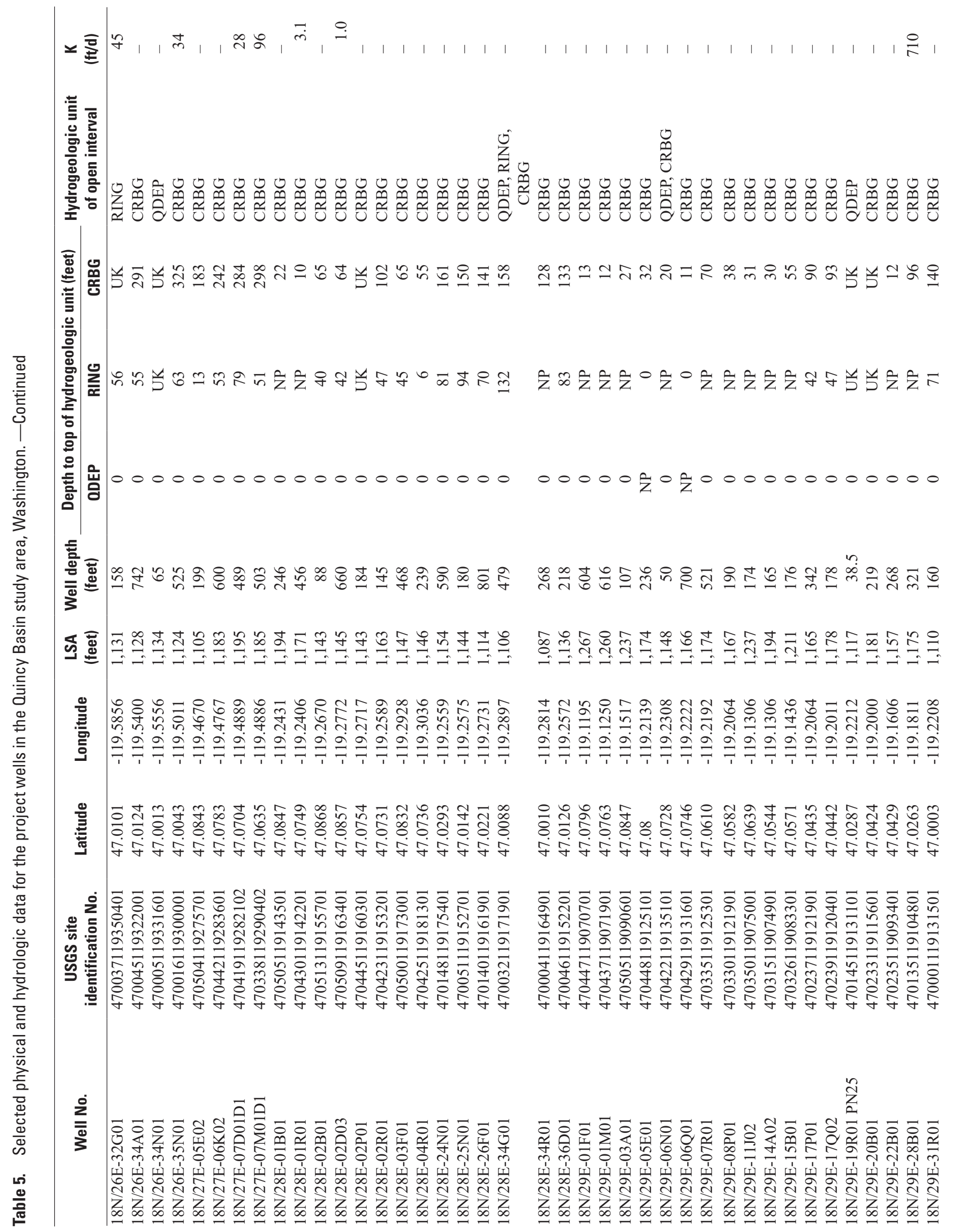




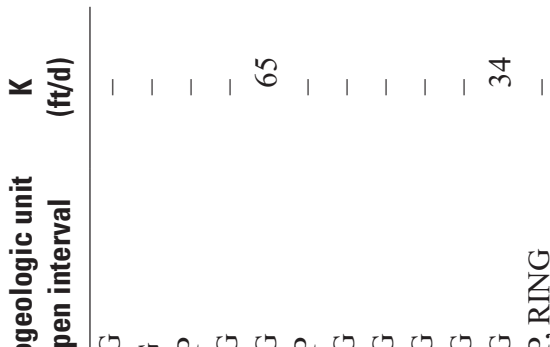

峞

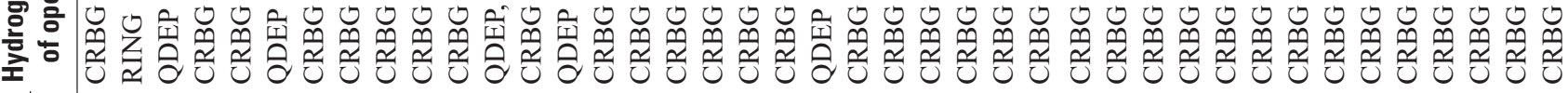

酯

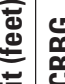

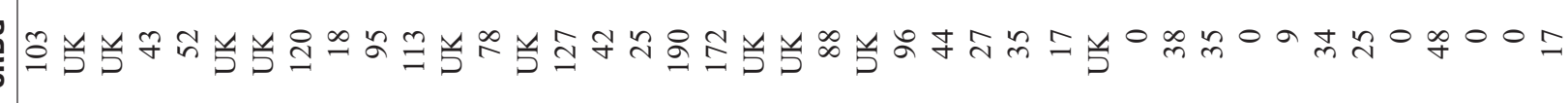

음

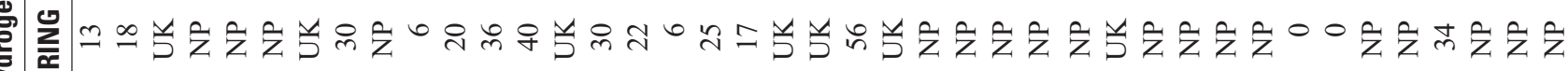
ํㅡㄹ

言

号声

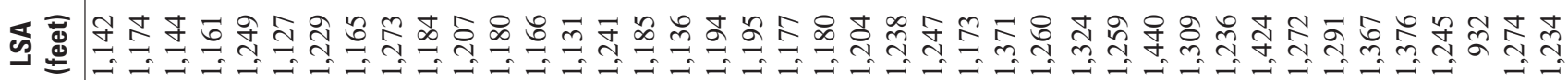

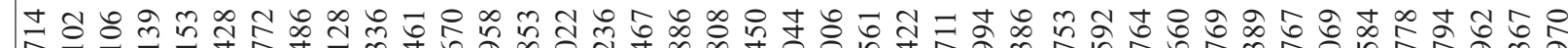

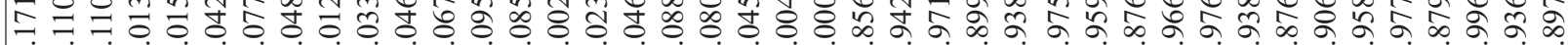

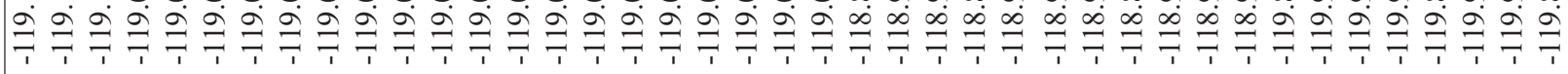

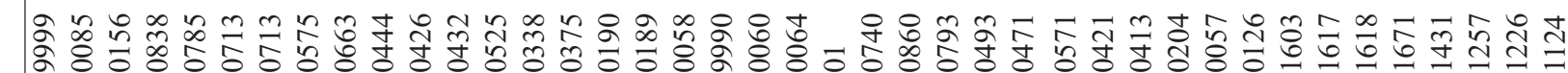

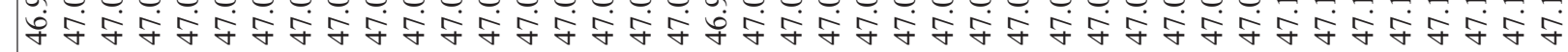

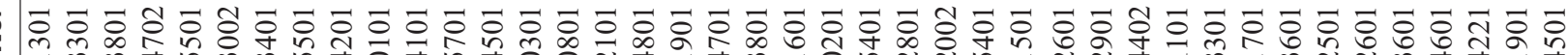
㐘.

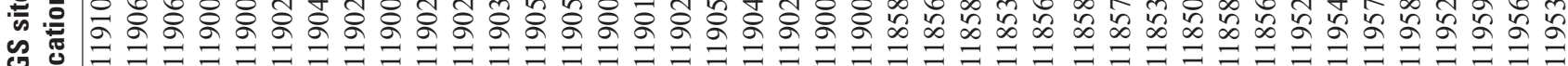

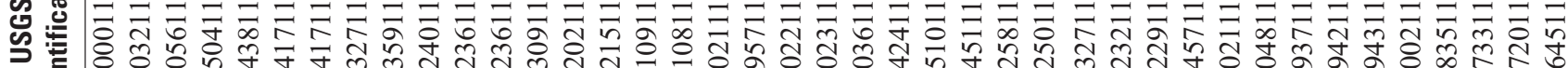

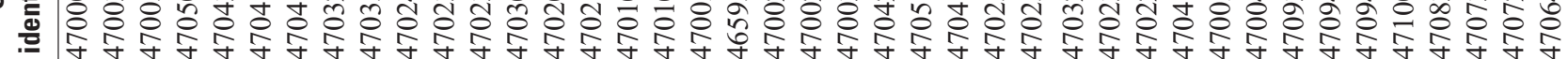

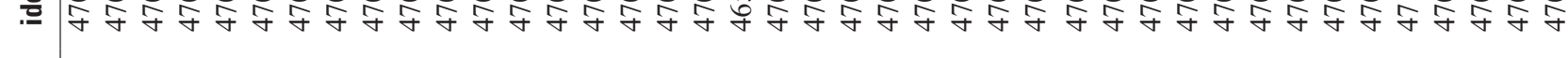

艿氞

i 空

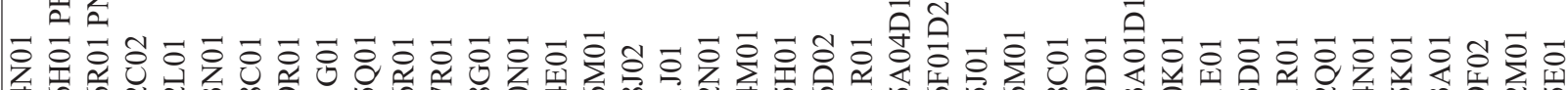

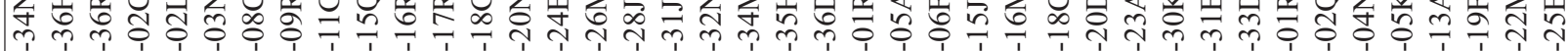

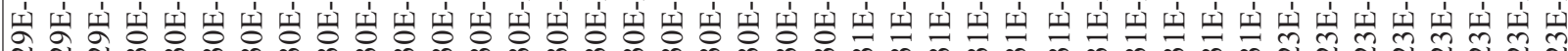

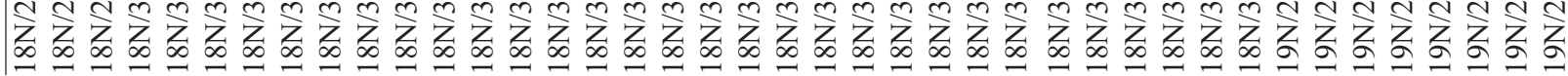




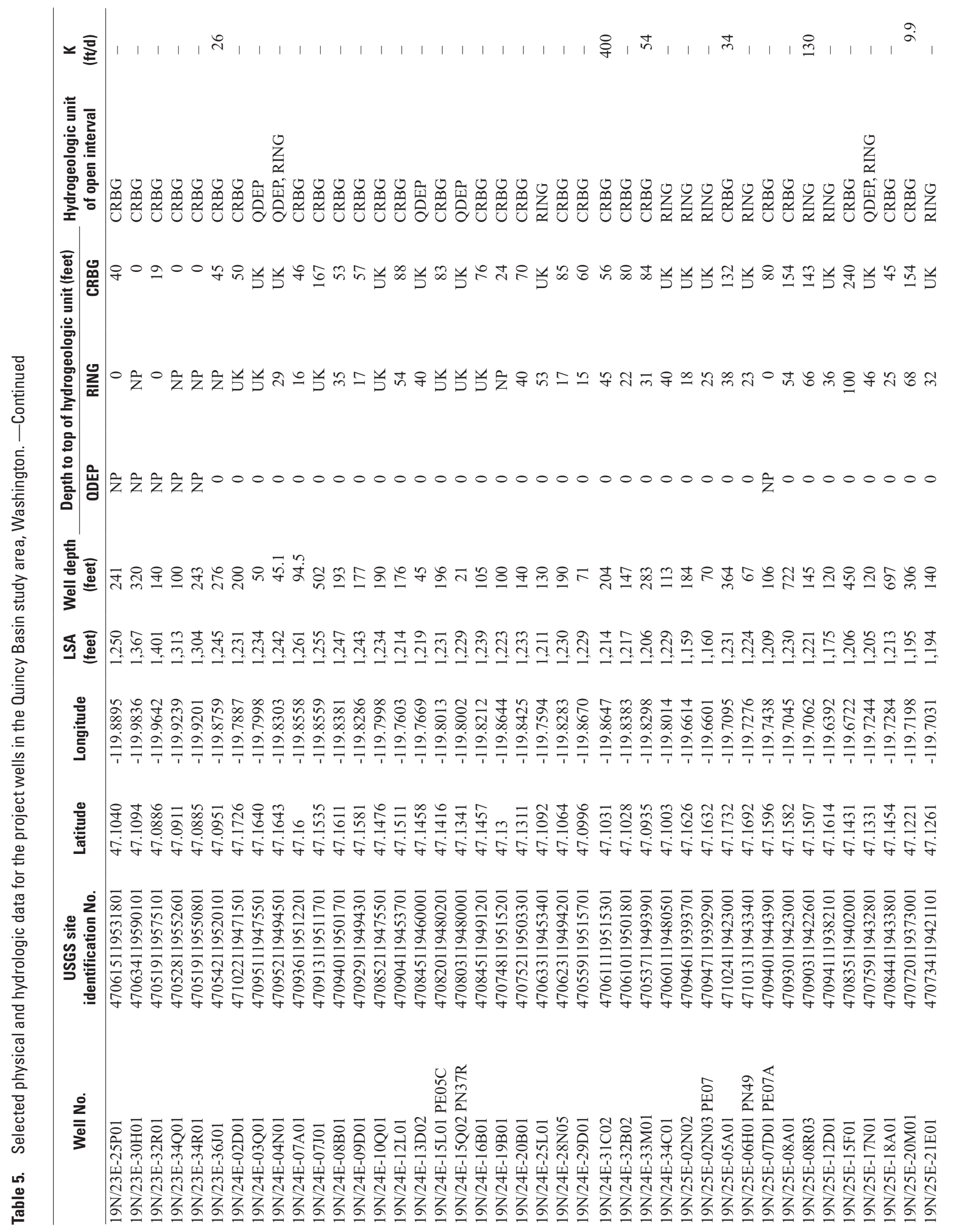




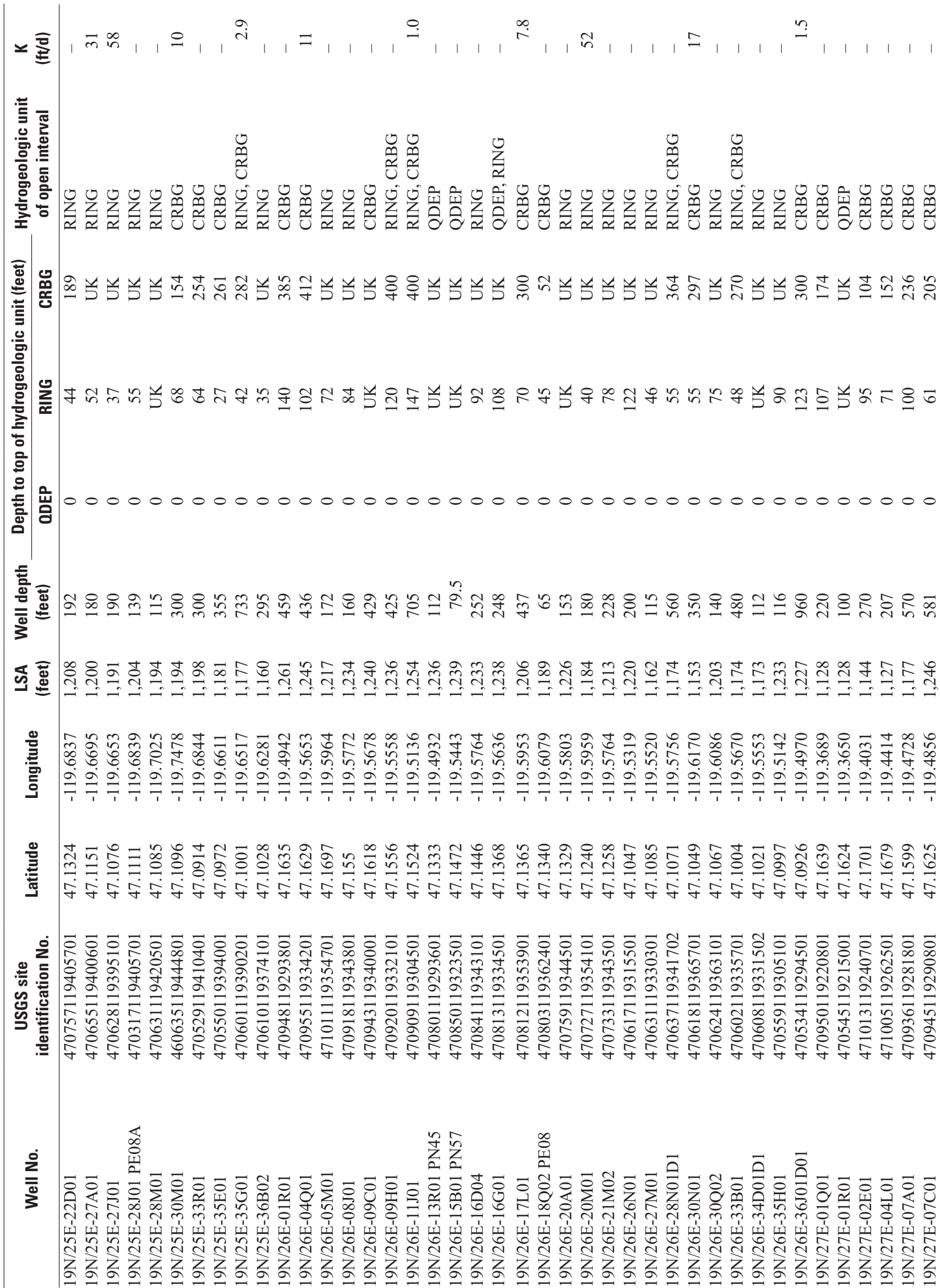




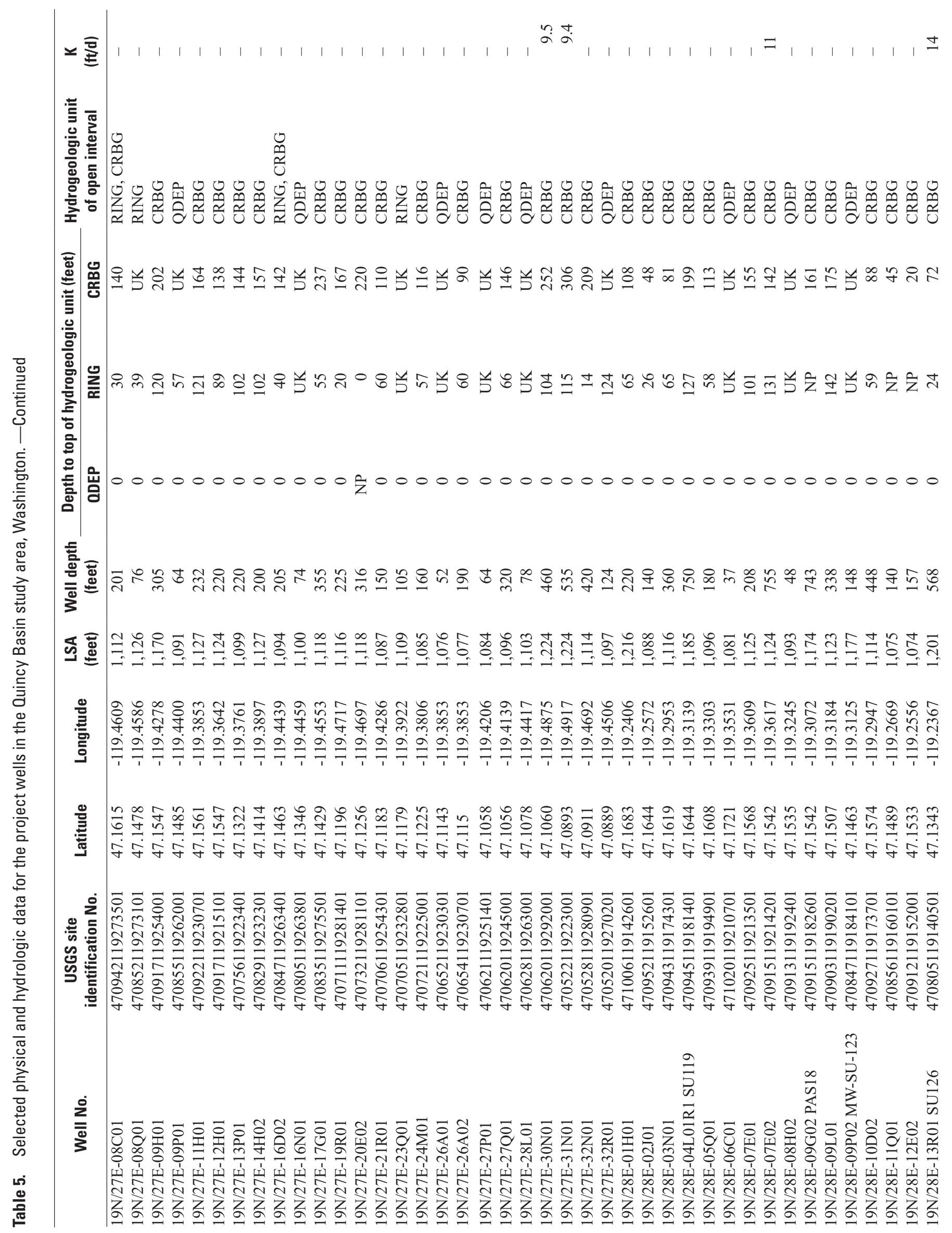




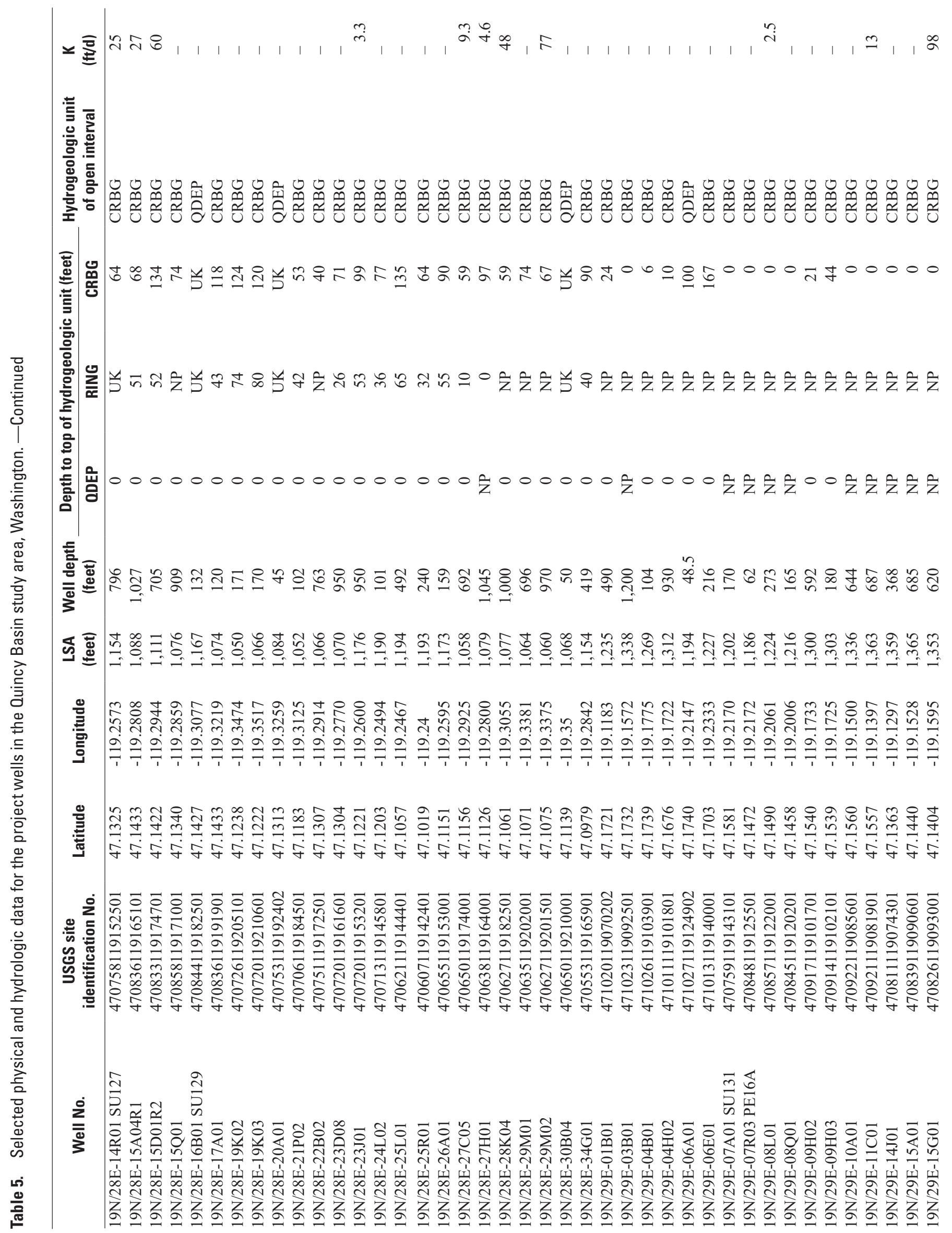




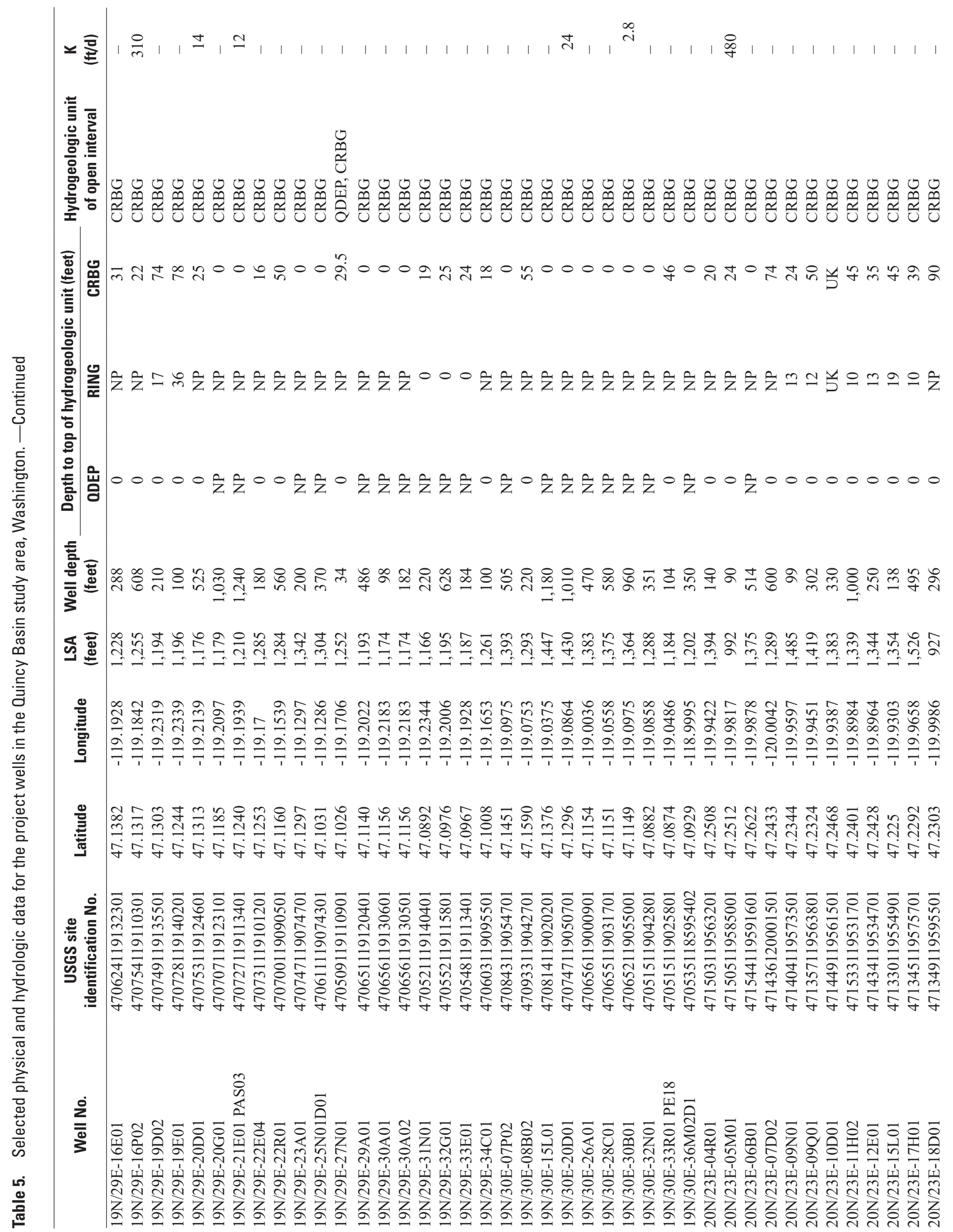




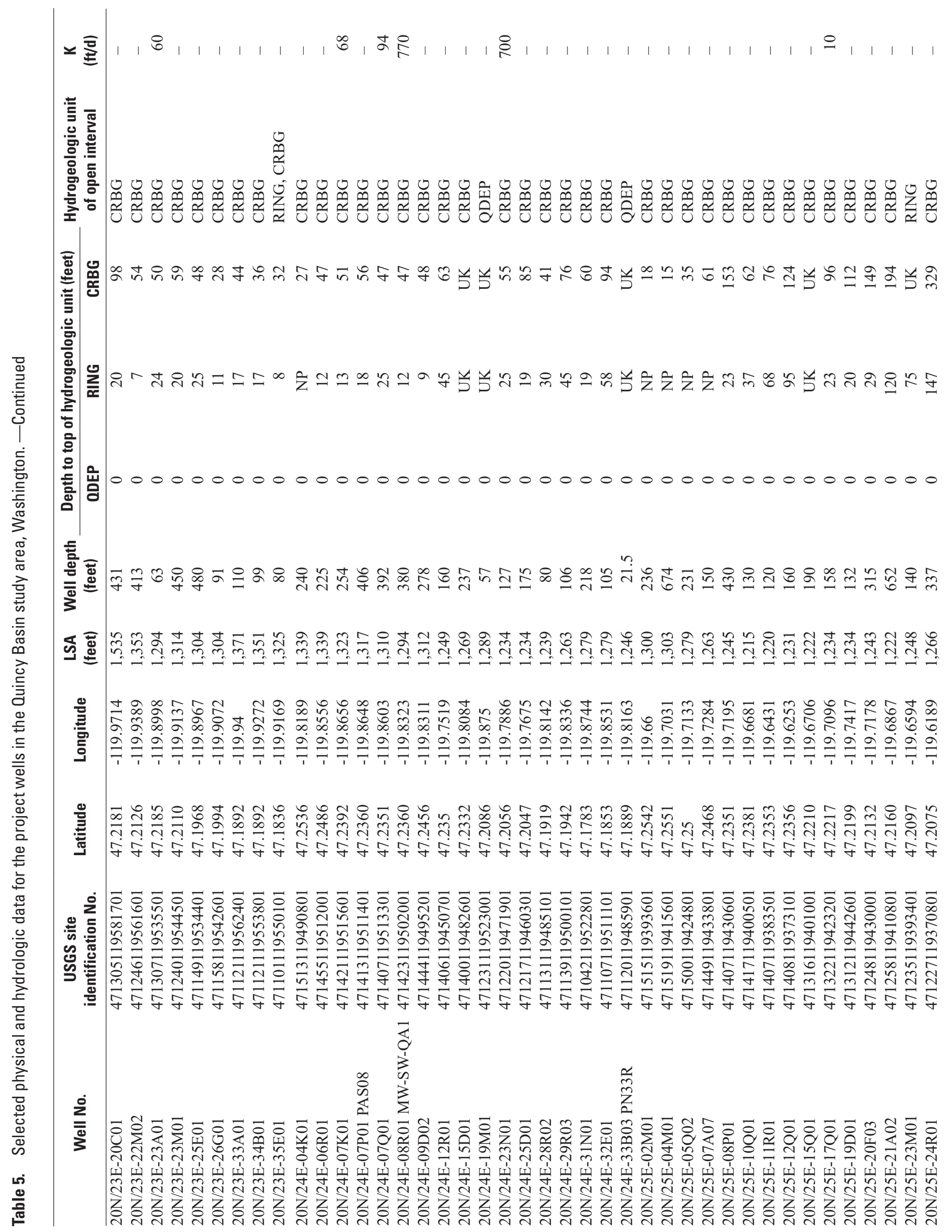




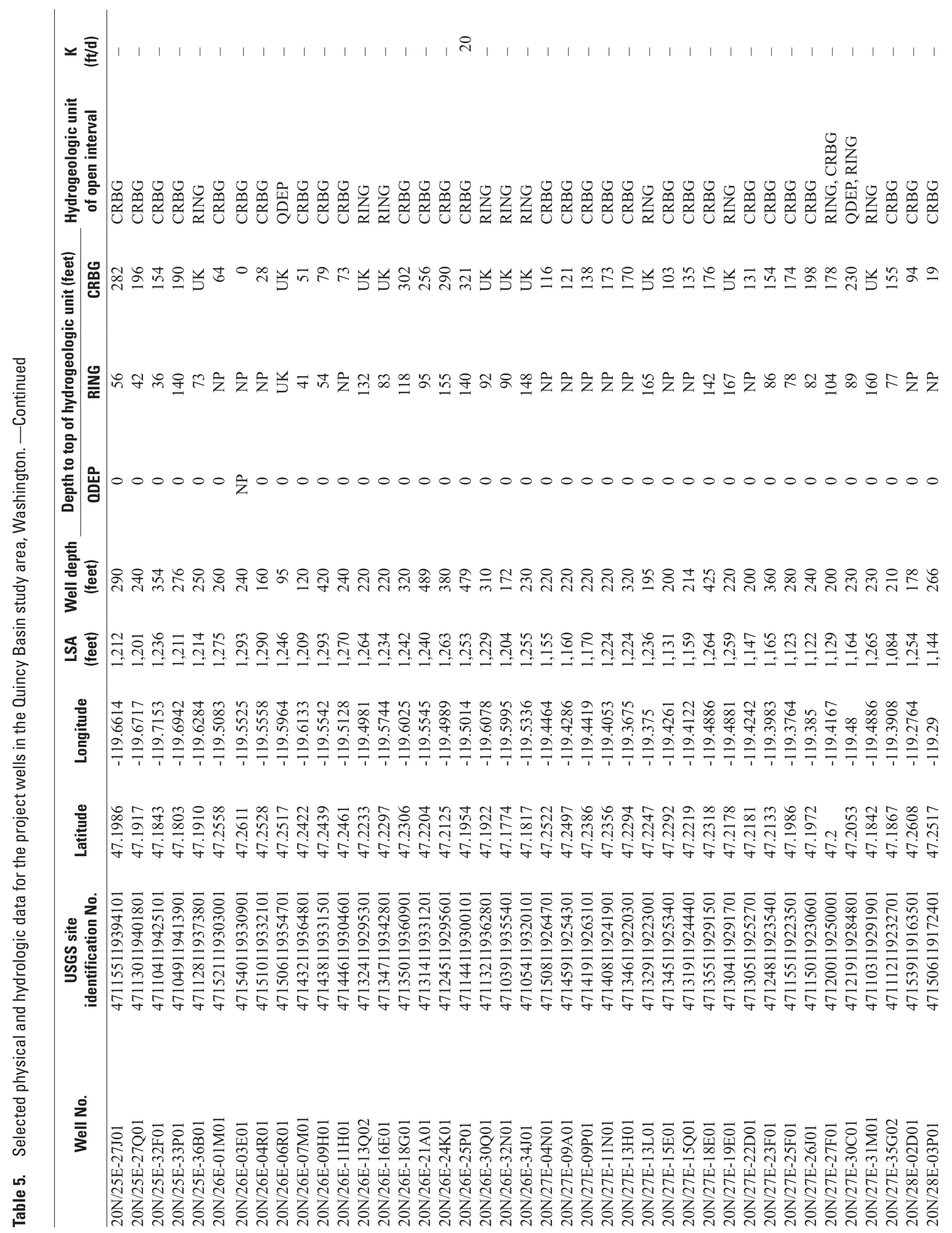




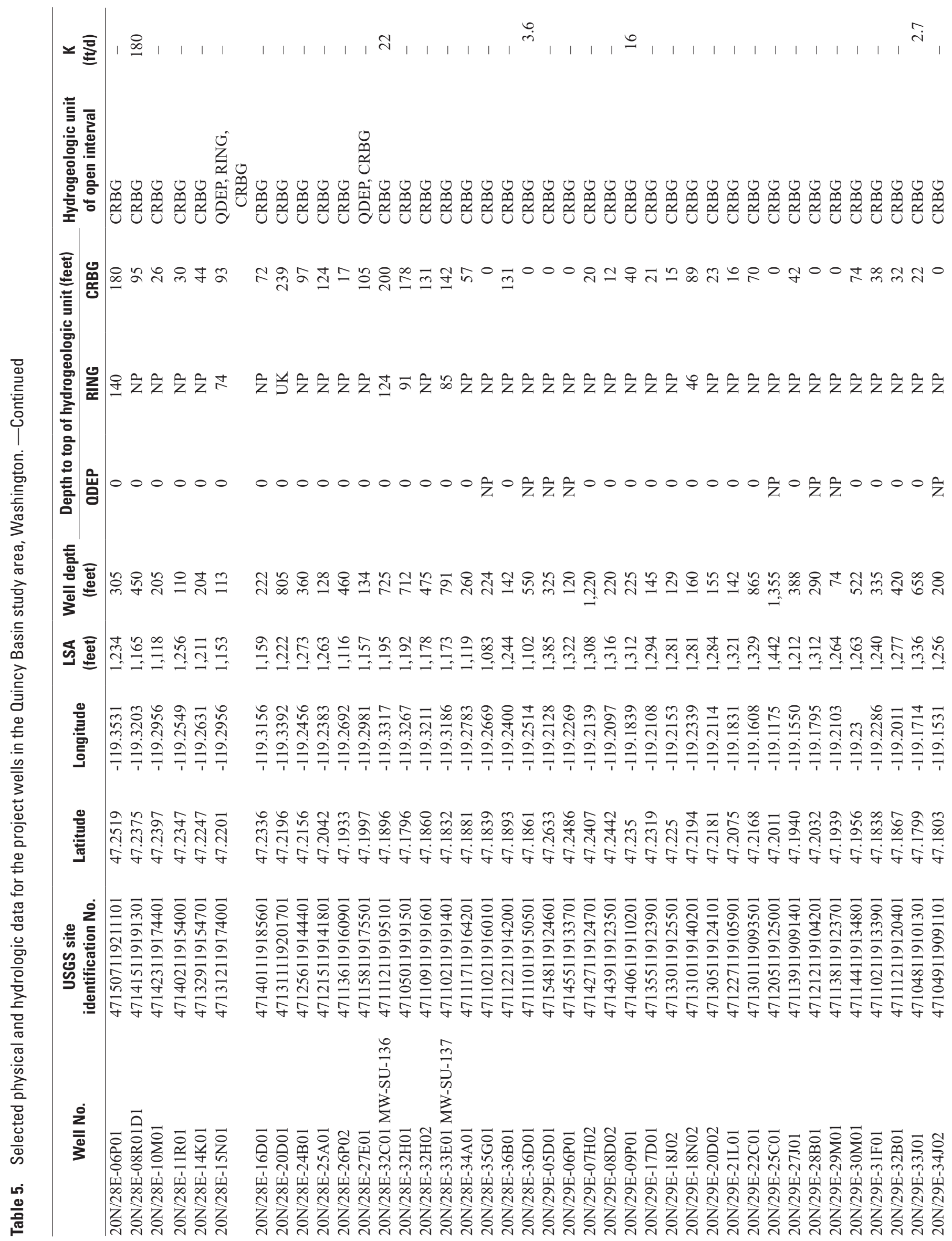




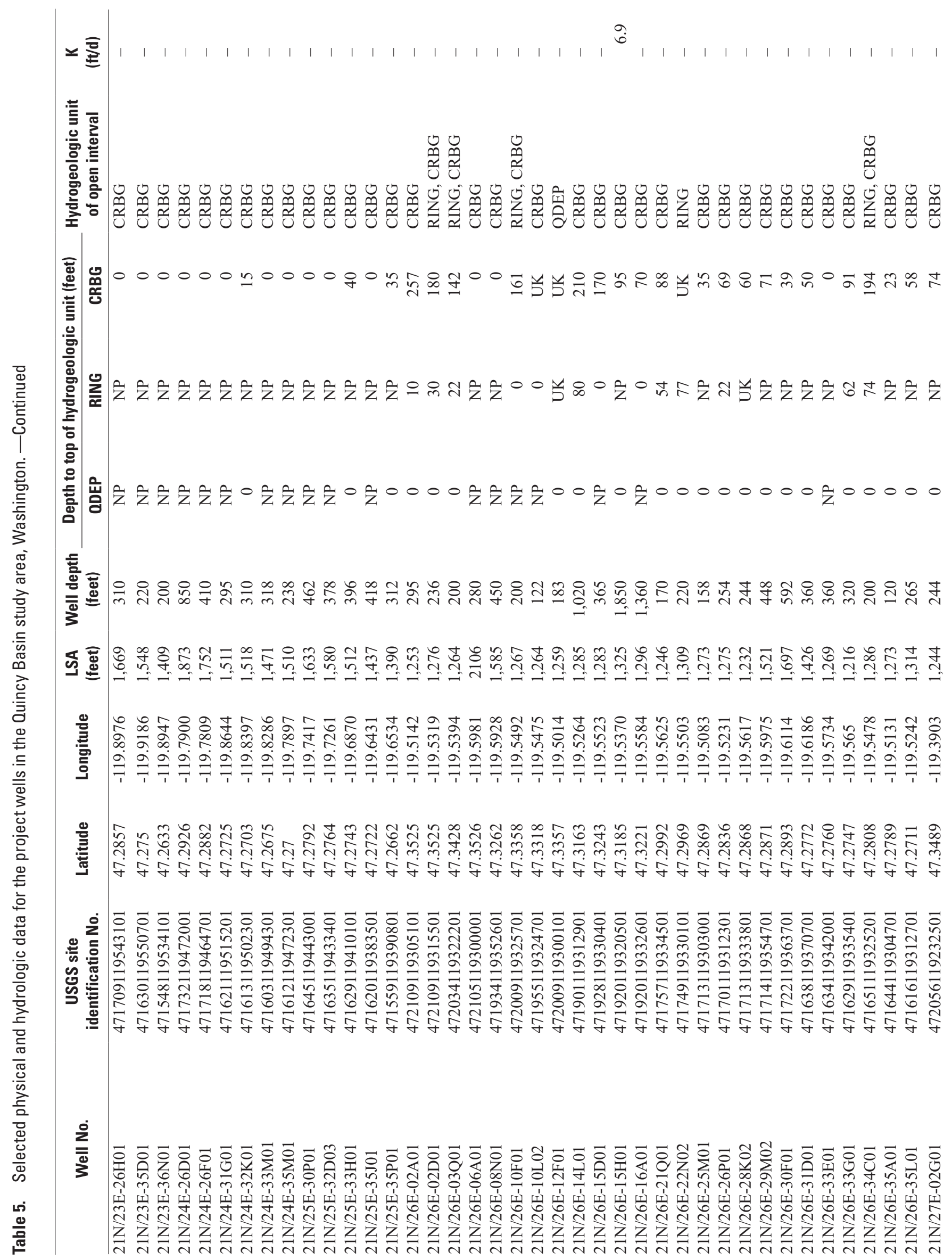




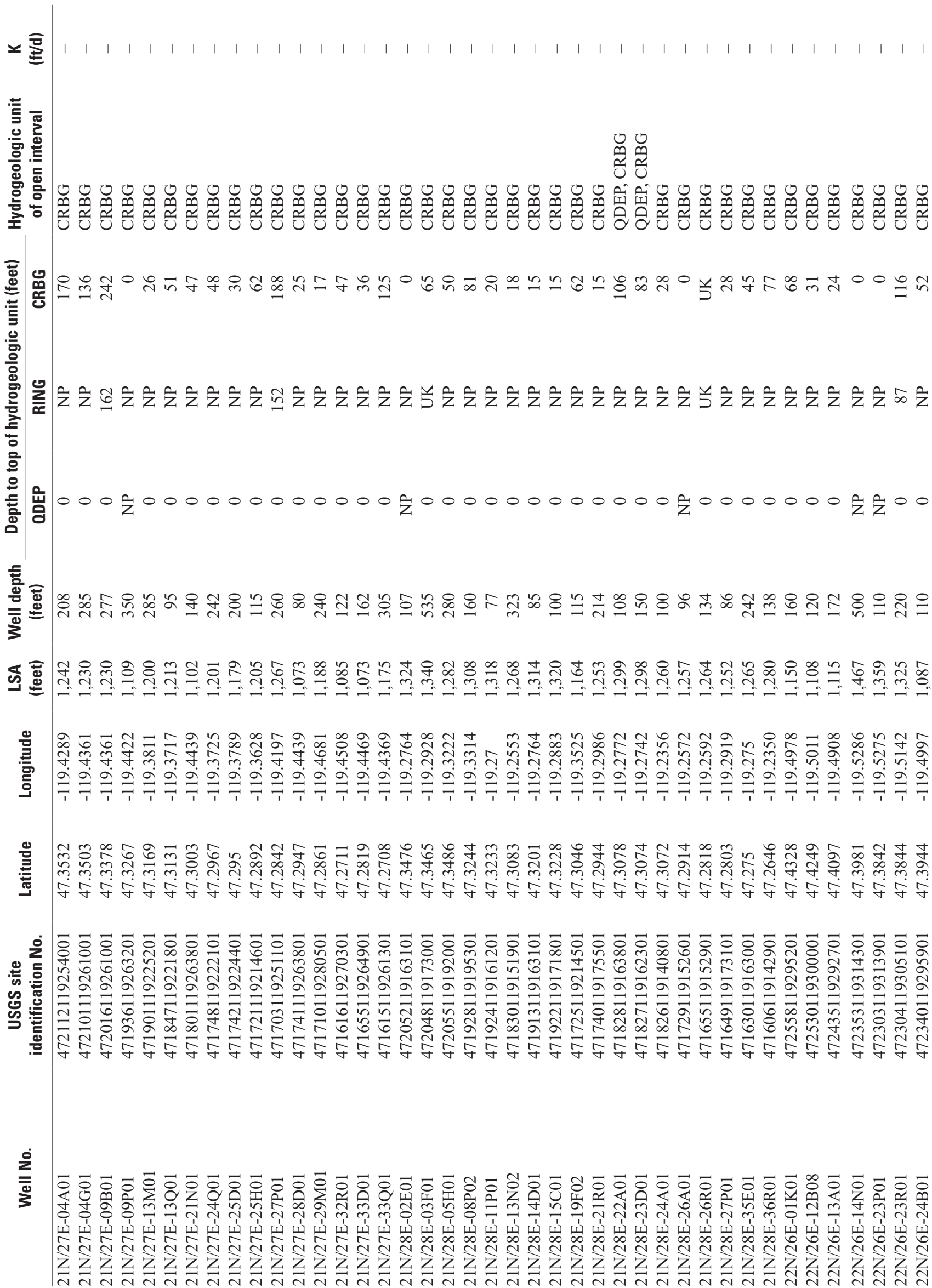




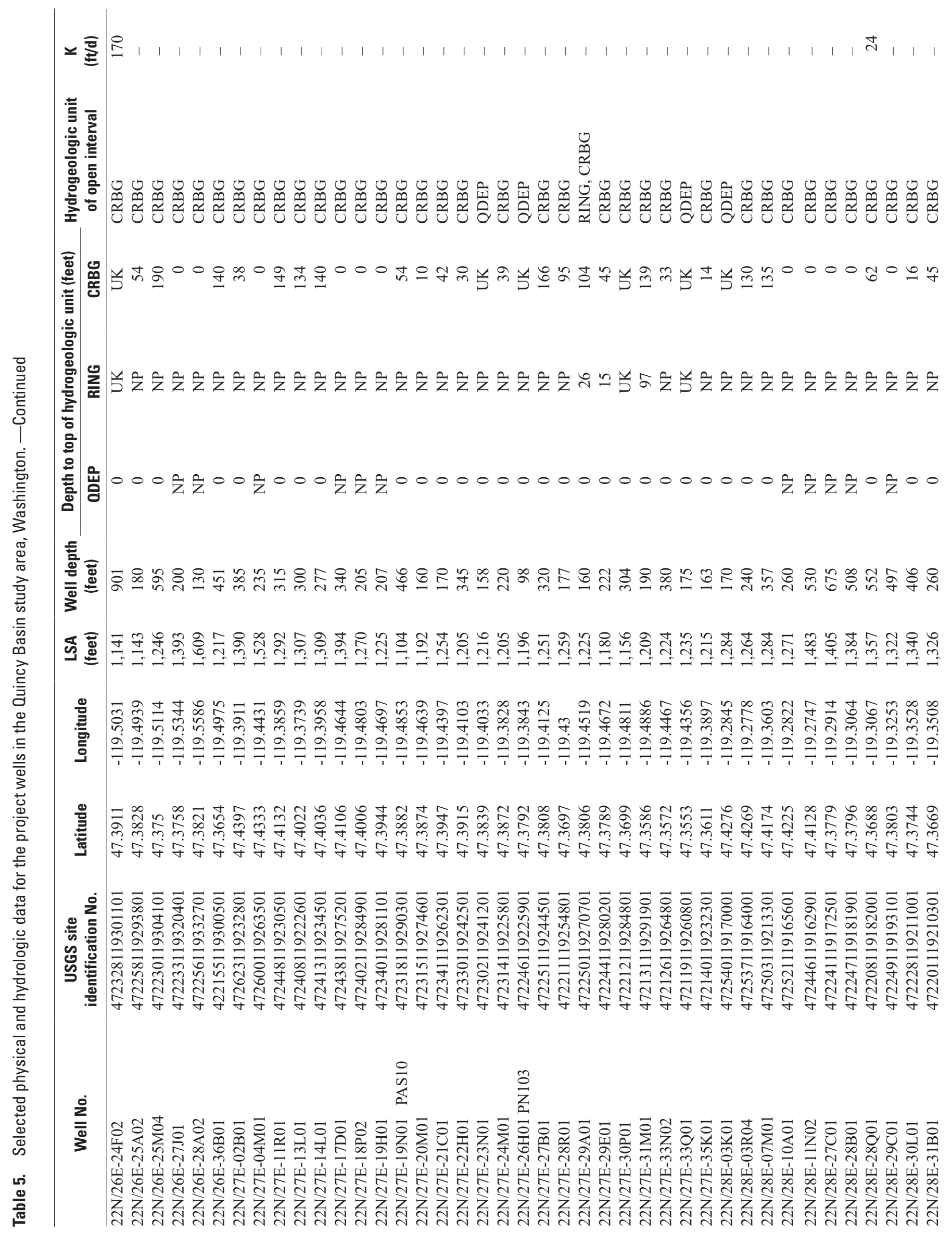




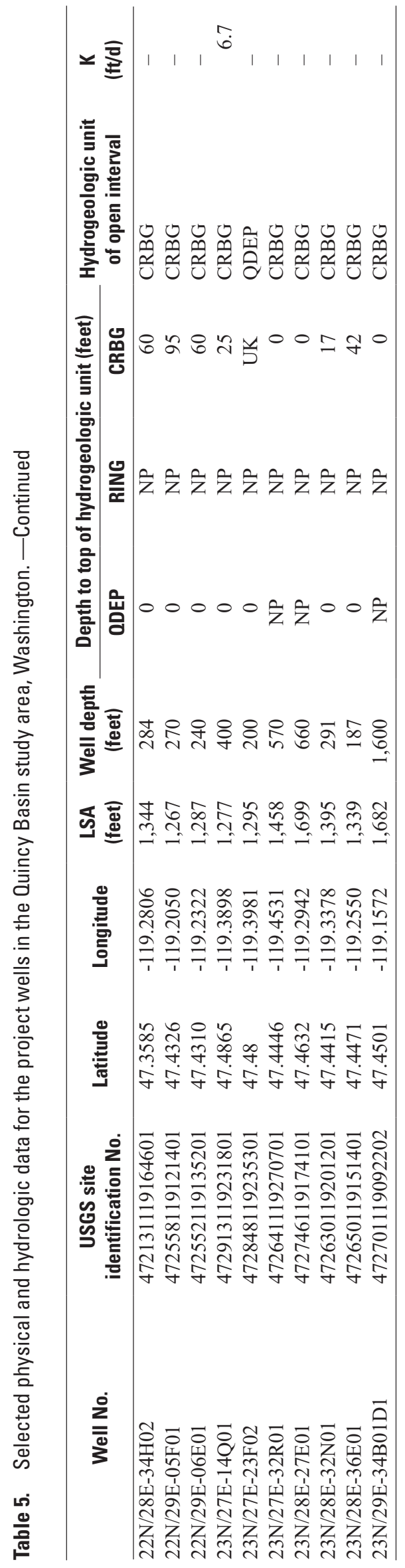



Publishing support provided by the U.S. Geological Survey Science Publishing Network, Tacoma Publishing Service Center

For more information concerning the research in this report, contact the Director, Washington Water Science Center

U.S. Geological Survey

934 Broadway, Suite 300

Tacoma, Washington 98402

https://www.usgs.gov/centers/wa-water 


\section{$\mathbb{R}$ \\ 总}

ڤ)

을

웋

कs

吾

$\stackrel{ }{\circ}$

옴

g

을

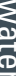

苋

올

㤩

宽

을

एా

$\stackrel{5}{3}$.

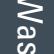

鲁.

을

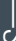

蛋

হ⿳亠丷厂

咅.

욤

깡

$\stackrel{\sim}{\circ}$

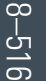

ISSN 2328-0328 (online) 